\title{
Sudden large-volume detachments of low-angle mountain glaciers - more frequent than thought?
}

\author{
Andreas Kääb ${ }^{1, \text { o }}$, Mylène Jacquemart ${ }^{2}$, Adrien Gilbert ${ }^{3}$, Silvan Leinss $^{4}$, Luc Girod ${ }^{1}$, Christian Huggel ${ }^{5}$, \\ Daniel Falaschi $^{6,7}$, Felipe Ugalde ${ }^{8,9}$, Dmitry Petrakov $^{10}$, Sergey Chernomorets $^{10}$, Mikhail Dokukin $^{11}$, Frank Paul ${ }^{5}$, \\ Simon Gascoin ${ }^{12}$, Etienne Berthier ${ }^{13}$, and Jeffrey S. Kargel ${ }^{14}$ \\ ${ }^{1}$ Department of Geosciences, University of Oslo, Oslo, Norway \\ ${ }^{2}$ Cooperative Institute for Research in Environmental Sciences, University of Colorado at Boulder, Boulder, United States \\ ${ }^{3}$ Université Grenoble Alpes, CNRS, IGE, Grenoble, France \\ ${ }^{4}$ Institute of Environmental Engineering, ETH Zurich, Zurich, Switzerland \\ ${ }^{5}$ Department of Geography, University of Zurich, Zurich, Switzerland \\ ${ }^{6}$ Instituto Argentino de Nivología, Glaciología y Ciencias Ambientales, Mendoza, Argentina \\ ${ }^{7}$ Departamento de Geografía, Facultad de Filosofía y Letras, Universidad Nacional de Cuyo, Mendoza, Argentina \\ ${ }^{8}$ Geoestudios, San José de Maipo, Chile \\ ${ }^{9}$ Departamento de Geología, Facultad de Ciencias Físicas y Matemáticas, Universidad de Chile, Santiago, Chile \\ ${ }^{10}$ Faculty of Geography, M. V. Lomonosov Moscow State University, Moscow, Russia \\ ${ }^{11}$ High-Mountain Geophysical Institute, Nalchik, Russia \\ ${ }^{12}$ CESBIO, Université de Toulouse, CNES/CNRS/INRA/IRD/UPS, Toulouse, France \\ ${ }^{13}$ LEGOS, CNES, CNRS, IRD, UPS, Université de Toulouse, Toulouse, France \\ ${ }^{14}$ Planetary Science Institute, University of Arizona, Tucson, AZ, USA \\ 욤ited contribution by Andreas Kääb, recipient of the EGU Louis Agassiz Medal 2019.
}

Correspondence: Andreas Kääb (kaeaeb@geo.uio.no)

Received: 20 August 2020 - Discussion started: 22 October 2020

Revised: 7 February 2021 - Accepted: 21 February 2021 - Published: 12 April 2021

\begin{abstract}
The detachment of large parts of low-angle mountain glaciers resulting in massive ice-rock avalanches have so far been believed to be a unique type of event, made known to the global scientific community first for the 2002 Kolka Glacier detachment, Caucasus Mountains, and then for the 2016 collapses of two glaciers in the Aru range, Tibet. Since 2016, several so-far unrecognized low-angle glacier detachments have been recognized and described, and new ones have occurred. In the current contribution, we compile, compare, and discuss 20 actual or suspected large-volume detachments of low-angle mountain glaciers at 10 different sites in the Caucasus, the Pamirs, Tibet, Altai, the North American Cordillera, and the Southern Andes. Many of the detachments reached volumes in the order of 10-100 million $\mathrm{m}^{3}$. The similarities and differences between the presented cases indicate that glacier detachments often involve a coincidental combination of factors related to the lowering of basal
\end{abstract}

friction, high or increasing driving stresses, concentration of shear stress, or low resistance to exceed stability thresholds. Particularly soft glacier beds seem to be a common condition among the observed events as they offer smooth contact areas between the glacier and the underlying substrate and are prone to till-strength weakening and eventually basal failure under high pore-water pressure. Partially or fully thawed glacier bed conditions and the presence of liquid water could thus play an important role in the detachments. Surface slopes of the detached glaciers range between around $10^{\circ}$ and $20^{\circ}$. This may be low enough to enable the development of thick and thus large-volume glaciers while also being steep enough to allow critical driving stresses to build up. We construct a simple slab model to estimate ranges of glacier slope and width above which a glacier may be able to detach when extensively losing basal resistance. From this model we estimate that all the detachments described in this 
study occurred due to a basal shear stress reduction of more than $50 \%$. Most of the ice-rock avalanches resulting from the detachments in this study have a particularly low angle of reach, down to around $5^{\circ}$, likely due to their high ice content and connected liquefaction potential, the availability of soft basal slurries, and large amounts of basal water, as well as the smooth topographic setting typical for glacial valleys. Lowangle glacier detachments combine elements and likely also physical processes of glacier surges and ice break-offs from steep glaciers. The surge-like temporal evolution ahead of several detachments and their geographic proximity to other surge-type glaciers indicate the glacier detachments investigated can be interpreted as endmembers of the continuum of surge-like glacier instabilities. Though rare, glacier detachments appear to be more frequent than commonly thought and disclose, despite local differences in conditions and precursory evolutions, the fundamental and critical potential of low-angle soft glacier beds to fail catastrophically.

\section{Introduction}

After the detachment of Kolka Glacier in the Russian Caucasus 14 years ago, the 17 July and 21 September 2016 detachments of two neighbouring glaciers in Tibet's Aru range directed attention to a new type of glacier instability that had been rarely observed and little described before (Tian et al., 2017; Gilbert et al., 2018; Kääb et al., 2018). The detachment of Kolka Glacier on 20 September 2002 released $130 \times 10^{6} \mathrm{~m}^{3}$ of ice and rock that claimed $\sim 135$ lives. Situated near a dormant volcano, Mount Kazbek, it was long assumed that the Kolka Glacier catastrophe was unique and specific to the glacier's location (Haeberli et al., 2004; Huggel et al., 2005; Drobyshev, 2006; Evans et al., 2009b). The Aru twin glacier detachments - which released 68 and $83 \times 10^{6} \mathrm{~m}^{3}$ of glacier ice without known conditions of high geothermal flux - have recently raised the questions of whether and where such events may have happened before or need to be expected in the future, what conditions allow low-angle glaciers to detach catastrophically from their beds, and what this means for mountain hazard management. The urgency of these questions is highlighted by the fact that several detachments similar to the Aru events, though smaller, have been detected subsequently (Falaschi et al., 2019; Paul, 2019; Jacquemart et al., 2020).

In contrast to glacier detachments, glacier surges are an extensively studied, though still not fully understood type of glacier instability. Characterized by unusually high ice-flow speeds of up to tens of metres per day over large parts of a glacier, glacier surges last weeks to several years (Harrison and Post, 2003; Jiskoot, 2011; Harrison et al., 2015; Truffer et al., 2021). Clusters of surge-type glaciers are found in many mountain regions around the world (Sevestre and Benn, 2015). The lowering of basal glacier friction that is as- sociated with surging involves abnormally high water pressure, changes in the thermal regime, and/or responses of subglacial till to increasing shear stress and water input (Clarke et al., 1984; Kamb, 1987; Truffer et al., 2000; Fowler et al., 2001; Murray et al., 2003; Frappe and Clarke, 2007; Sevestre et al., 2015; Benn et al., 2019).

A second, well-known type of glacier instability happens over a wide range of magnitudes, from icefalls at steep glacier fronts to large ice avalanches when partial or entire ice volumes suddenly break off from hanging glaciers that are typically steeper than around $30^{\circ}$ (Alean, 1985; Huggel, 2009; Faillettaz et al., 2015). The latter empirical value from literature offers a slope threshold to separate the definitions of ice avalanches from glacier detachments. Impacts associated with ice avalanches, which typically have volumes much smaller than $1 \times 10^{6} \mathrm{~m}^{3}$, are usually limited to a few kilometres unless the failed ice transforms into a highly mobile mass flow through liquefaction and the incorporation of wet sediments or water in the path (Petrakov et al., 2008; Evans and Delaney, 2015). Failure conditions and triggering factors of such steep ice avalanches typically include glacier geometry (steep ramp-type glaciers, bedrock edges), bedrock topography (e.g. convex bed), atmospheric events (e.g. temperature increase), increasing accumulation rates, ice thermal conditions (e.g. frozen base or changes therein), instabilities of the underlying bedrock that take with them ice resting on it, or seismic events (Alean, 1985; van der Woerd et al., 2004; Huggel, 2009; Fischer et al., 2013; Faillettaz et al., 2015).

Compared to the two types of glacier instability above, sudden large-scale detachments of mountain glaciers, primarily occurring at low bed slopes, are much less frequent. However, due to a mobility at least as high as that of ice avalanches, combined with large volumes, glacier detachments can constitute a severe threat to communities and settlements located in remote areas.

In general, mass movements that result from sudden slope failures in ice- or snow-rich mountain environments are particularly mobile, leading to strongly increased runout distances compared to ice- and snow-free conditions (Petrakov et al., 2008; Huggel, 2009; Schneider et al., 2011; Evans and Delaney, 2015). Frictional heating melts ice and snow components, which are either part of the initial slope failure or incorporated along the avalanche path. Liquid water embedded in the glacier and sediments before failure can amplify the avalanche mobility. Also ice and snow surfaces, in cases when the avalanche travels over those, are able to reduce basal friction. Here, we define sudden large-volume glacier detachments through their initiation, while the eventually resulting ice-rock avalanches might be similar to those resulting from other high-mountain slope instabilities. By terming these events low-angle glacier detachments, we follow the suggestion of Evans and Delaney (2015) who describe the Kolka case as the large-scale detachment of a valley glacier. Other authors, for instance, called these failure events glacier 
slides in reference to landslides (Petrakov et al., 2008), or glacier collapses (Kääb et al., 2018).

The following selection focusses on detachments $\gg 1 \times 10^{6} \mathrm{~m}^{3}$ and from glaciers with surface slopes of less than around $20^{\circ}$, i.e. focussing on glaciers from which large-volume detachments are not expected. We are well aware that it can be reasonable to include events beyond the limits of these criteria in analyses depending on the goal of the investigation and that similar events beyond the limits of these criteria could involve the same mechanisms that are discussed here. The main scientific purpose of this paper is to provide an overview of all known glacier detachments either by summarizing existing detailed studies or by providing such details for the first time (see Supplement Table S1 for existing studies and new contributions by the present work). We aim to show and discuss the relation of low-angle glacier detachments to glacier surges and the continuum of high-mountain ice and rock instabilities, such as normal avalanches. The main applied purpose of our study is to make experts involved in high-mountain hazard management aware of the so far little recognized possibility for glacier detachments and to discuss related potential key indicators and how climate change could factor into the mechanisms.

\section{Ice-rock avalanches and glacier surges}

In this section, we draw some comparisons of low-angle glacier detachments to (1) more typical types of glacier ice and ice-rock avalanches and (2) glacier surges. The detachment process sequence combines elements of both of these but in a combination and under conditions that are distinct.

Glacier detachments lead to ice-rock avalanches, but icerock avalanches usually are the result of other different initial types of slope failures and event cascades. A wide range of magnitudes, avalanche compositions, and impacts have been observed (Schneider et al., 2011). In this section, we exemplify the diverse characteristics of ice-rock avalanches and the resultant mass flows in order to contrast them to sudden large-volume detachments of mountain glaciers. We use the extensive data collection from Schneider et al. (2011) as the background data set for our study, extended by events from Petrakov et al. (2008). In Fig. 1, each event of this combined data set is plotted as a grey circle according to its horizontal reach $(L)$, elevation difference $(H)$, and detachment volume $(V)$. The size of the circles in Fig. 1a indicates the detachment volumes. The ratio $H / L$ is the apparent friction coefficient or the angle of reach, also called "Fahrböschung", calculated from the uppermost scarp of the slope failure to the lowermost part of the mass movement deposits. Dark grey circles mark the following examples, standing out mainly by type, volume, and angle of reach.

In the 1970 Huascarán (Peru) event (and a similar event in 1962), a rock-wall failure triggered by a M7.9 earthquake incorporated large amounts of ice from above and be- low it, leading to a highly mobile and far reaching ice-rock avalanche of $80 \times 10^{6} \mathrm{~m}^{3}$ that claimed up to 20000 lives (e.g. Evans et al., 2009a). In Fig. 1, we use the solid deposits of the avalanche to define its reach and elevation difference, neglecting that a subsequent water and mud flood travelled much farther (indicated by * symbols in Fig. 1). The 1970 Huascarán avalanche is one of the largest, farthest reaching, and by far deadliest known ice-rock avalanche.

A rock failure in the Chilean Andes in 1987 incorporated ice, snow, and water which transformed the avalanche into a debris flow of $15 \times 10^{6} \mathrm{~m}^{3}$ that sped down the Estero Parraguirre valley and killed more than 37 people (Hauser, 2002). In our collection, this is the farthest-reaching event (lowest angle of reach; $H / L \sim 0.12$ ) that did not originate as a glacier detachment.

The 1964/65 Allen Glacier event, Alaska, is an example of a very large rock avalanche, likely triggered by an earthquake, that was able to runout for an unusually long distance because it landed on a glacier (Post, 1968). Neighbouring glaciers show similar rock deposits from the same time, and also later earthquakes caused comparable rock avalanches that travelled far over low-angle glaciers (e.g. Shugar et al., 2012).

In $1895,5 \times 10^{6} \mathrm{~m}^{3}$ of at least partially cold-based ice sheared off $40^{\circ}$ steep bedrock from Altels Glacier in the Swiss Alps (glacier surface slopes indicated as numbers within the circles in Fig. 1a). The resulting ice avalanche rushed up the opposite side of the valley and thus did not reach its maximum runout distance (indicated by $\rightarrow$ symbols in Fig. 1; Faillettaz et al., 2011). The Altels event is an example of a very large, pure ice avalanche stemming from the detachment of a very steep glacier. Until it sheared off, the glacier was probably held in place by transverse bedrock riegels and cold patches or zones where it was frozen to its bed (Wagner, 1996).

A number of ice-rock avalanches have occurred from different locations on Iliamna volcano, Alaska, the last of which is documented in June 2019 (Toney et al., 2020). Failure surfaces were typically on the order of $40^{\circ}$, and volumes reached up to around $20 \times 10^{6} \mathrm{~m}^{3}$ (Caplan-Auerbach and Huggel, 2007; Huggel et al., 2007). These events show that enhanced geothermal heat fluxes can be involved in causing ice-rock avalanches.

In the following, we also put glacier detachments briefly in the context of glacier surges. An obvious difference between surges and glacier detachments is that the bed of surging glaciers does not fail catastrophically. A substantial body of research is available about glacier surging, covering, among others, surge cycles and phases and thermally and/or hydrologically driven surge mechanisms (see references in the Introduction). Some observations of surging mountain glaciers or their surge-like movements fall outside the norm of the majority of surges but will become of interest for some glacier detachments contained in this contribution. While the regional pattern of known glacier surges exhibits geographi- 


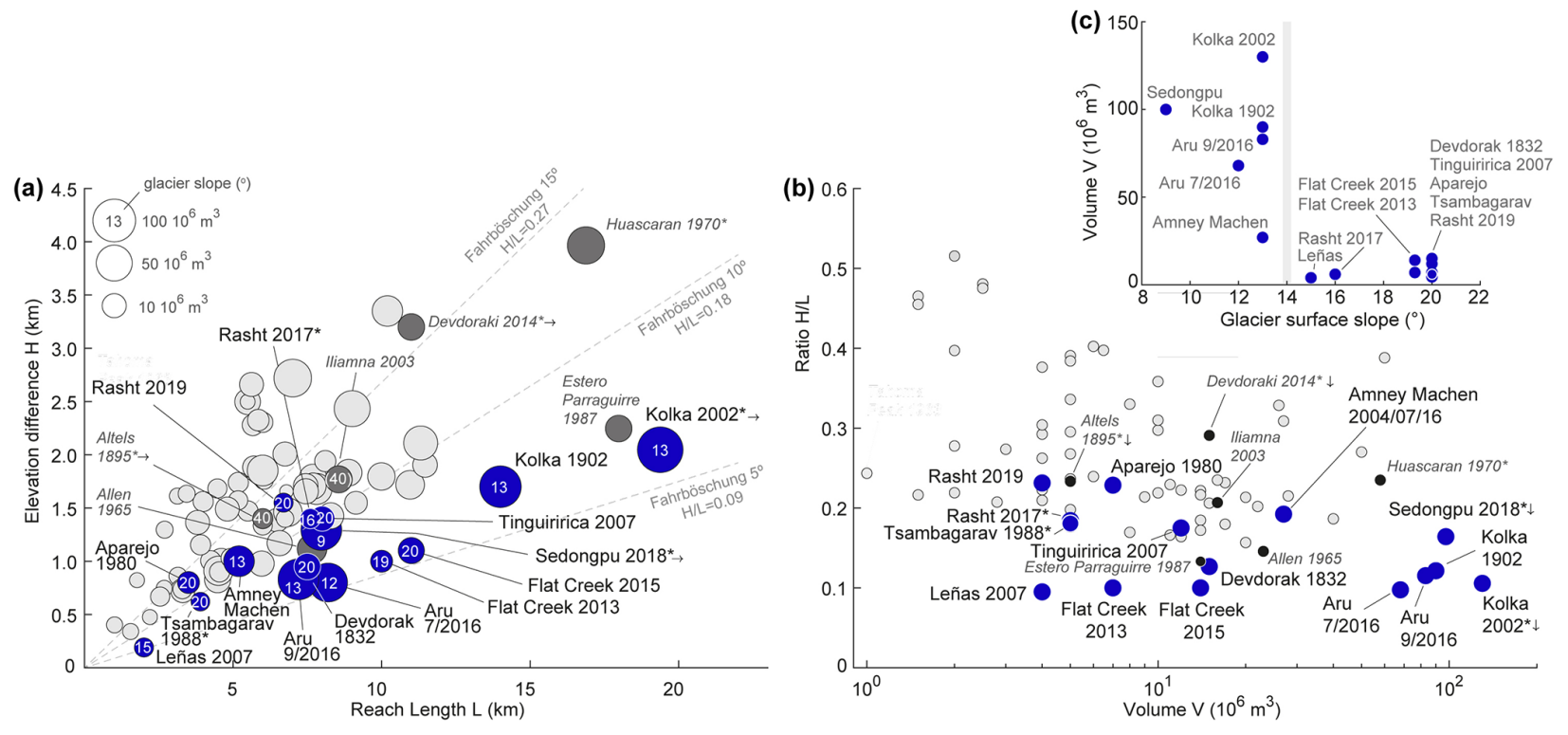

Figure 1. (a) Known avalanches of ice-rock mixtures plotted by elevation drop $H$ versus reach $L$. The event volumes are indicated by circle size (see legend to the upper left of panel a). Blue circles are sudden large-volume detachments of low-angle mountain glaciers, with the surface slope of the detached glacier parts given inside the circles. The grey circles are other ice-rock avalanche events, with dark grey events mentioned specifically in the text to illustrate different event types collected in this figure. The diagonal dashed lines indicate the angle of reach, Fahrböschung, at 5, 10, and $15^{\circ}$. (b) Events from (a) plotted by reach angle $(H / L)$ versus avalanche volume V. Note the logarithmic scale of the $x$ axis (volume). Most events stem from Schneider et al. (2011), extended by data from Petrakov et al. (2008) and the present study. ${ }^{*}$ after the event name indicates that a mud or debris flow continued from the ice-rock avalanche deposits, which is not considered in the calculation of the reach. Arrows behind the event name indicate that the avalanche was stopped by some obstacle and would otherwise have travelled farther. The direction of the arrow indicates the direction in which the event symbol would have shifted in the plot without the obstacle. (c) Glacier detachment volume against glacier surface slope. The grey vertical bar indicates a very rough boundary between the glacier slope of very large and smaller detachment volumes.

cal clusters (Sevestre and Benn, 2015), surge-like events are sometimes found far outside the known surge clusters, as was for example the case for the speed-up of Belvedere Glacier, Italian Alps, in the early 2000s (Haeberli et al., 2002; Kääb et al., 2004; Harrison et al., 2015; Truffer et al., 2021) (cf. Tsambagarav detachment; Sect. 3.4). Ice flow speeds associated with surges are typically 1 to 2 orders of magnitude higher than pre-surge speeds, up to several tens of metres per day, or about 5-6 orders of magnitudes slower than icerock avalanches. But there are known events that reached speeds of up to $1 \mathrm{~km} \mathrm{~h}^{-1}$, i.e. only about 2 orders of magnitude slower than the avalanches (Sect. 3.6.3; Zhang, 1992). Furthermore, the disintegration of surging (and non-surging) glaciers which did not lead to ice-rock avalanches have also been reported (e.g. Milana, 2007; Wang et al., 2021). Finally, another non-frequent behaviour of surge-type glaciers is extreme surface bulging that has been observed as a consequence of a polythermal ice structure (Clarke and Blake, 1991) (cf. e.g. Flat Creek detachments; Sect. 3.7).

\section{Glacier detachment events}

In the following, we summarize events that we categorize as glacier detachments, i.e. large-volume ice-rock avalanches from the sudden failure of low-angle parts of mountain glaciers (blue circles in Fig. 1) (Supplement Fig. S1; kmz file in Supplement). Based on previously published findings from several of the events, we focus our descriptions specifically on disposition factors that could contribute to or hint at the presence of particularly low basal friction and high driving stresses. These factors include soft sediments, polythermal ice conditions, abnormal geothermal heat flux, high water input and basal water pressure, glacier surging, additional ice or rock loading, and significant steepening in surface slope. As it has been shown that thermal conditions can also play a role in the detachments of glaciers (Gilbert et al., 2018; Jacquemart et al., 2020), we also try to evaluate permafrost conditions for each event.

We sort the following events by regions and proceed within the regions from short summaries of well-documented events to more detailed descriptions of not or little studied cases. Discussions of individual events, e.g. regarding presatellite era events or a possible recurrence by glacier recovery, are included in the respective subsections, whereas the 
main discussion in Sect. 4 focuses on the overall comparison between events.

\subsection{Mount Kazbek, Caucasus Mountains}

\subsubsection{Devdorak, 18th century, 19th century, 2014}

A number of suspected glacier detachments and ice-rock avalanches happened around Mount Kazbek at the border between Russia and Georgia. During the 18-19th centuries, surges of the Devdorak (Georgian name Devdoraki also used in literature) Glacier on the north-eastern flank of Mount Kazbek (Fig. 2; Table 1) were moving down the Amilishka River valley (Kabakhi River in its lower part), which drains the glacier catchment. Surge-like advances were recorded in 1776, 1778, 1785, 1808, 1817, and 1832 (Zaporozhchenko and Chernomorets, 2004). On $13 \mathrm{Au}-$ gust 1832, parts of the surging Devdorak Glacier tongue detached and the subsequent ice-rock avalanche blocked the main Terek valley, an important transportation route between Russia and Georgia (Petrakov et al., 2008). An eyewitness of the 1832 event, Engineer-colonel Grauert, estimated a volume of $15.5 \times 10^{6} \mathrm{~m}^{3}$ of ice and rock mass blocked the Dariali Gorge of the Terek valley (Zaporozhchenko and Chernomorets, 2004). The causes and mechanisms of this (and other) detachments are not well known and vary throughout the literature. Ice-rock avalanching onto the glacier, overloading, and the associated increase in subglacial water pressure could well have played a role.

Except for their source area, these at their time wellknown "Kazbek blockages" followed the same avalanche path as the 2014 Devdorak event described in the following. In 2014, parts of a rock wall and overlying hanging glaciers failed from Mount Kazbek (Figs. 2-3). The resulting highly mobile ice-rock avalanche of $2-5 \times 10^{6} \mathrm{~m}^{3}$ rushed down the Amilishka and Kabakhi valleys and blocked the main road between Russia and Georgia, killing nine people (Chernomorets et al., 2016; Tielidize et al., 2019). This event might also have had a longer runout (Fig. 1) but was stopped and the Dariali (or Terek) gorge. The 1832 Kazbek blockage is described as a glacier detachment in the sense of the present contribution in older literature, but more recent interpretations, not least based on the 2014 event, indicate that the 1832 event and other such events at the site might have started as rock failures rather than surges (Chernomorets, 2014; Chernomorets et al., 2016). We list the Kazbek blockages as potential glacier detachments here but stress that it remains uncertain what kind of event they actually were.

Currently, the entire narrow lower part of Devdorak Glacier has a surface slope of around $23^{\circ}$, its tongue closer to $17^{\circ}$. The volcanic nature of Mount Kazbek, the documentation of a number of violent mass flows from the mountain in the past (Chernomorets et al., 2007), field visits, and visual analysis of very high-resolution satellite images and terresby a sharp $90^{\circ}$ turn at the confluence of the Devdorak gorge

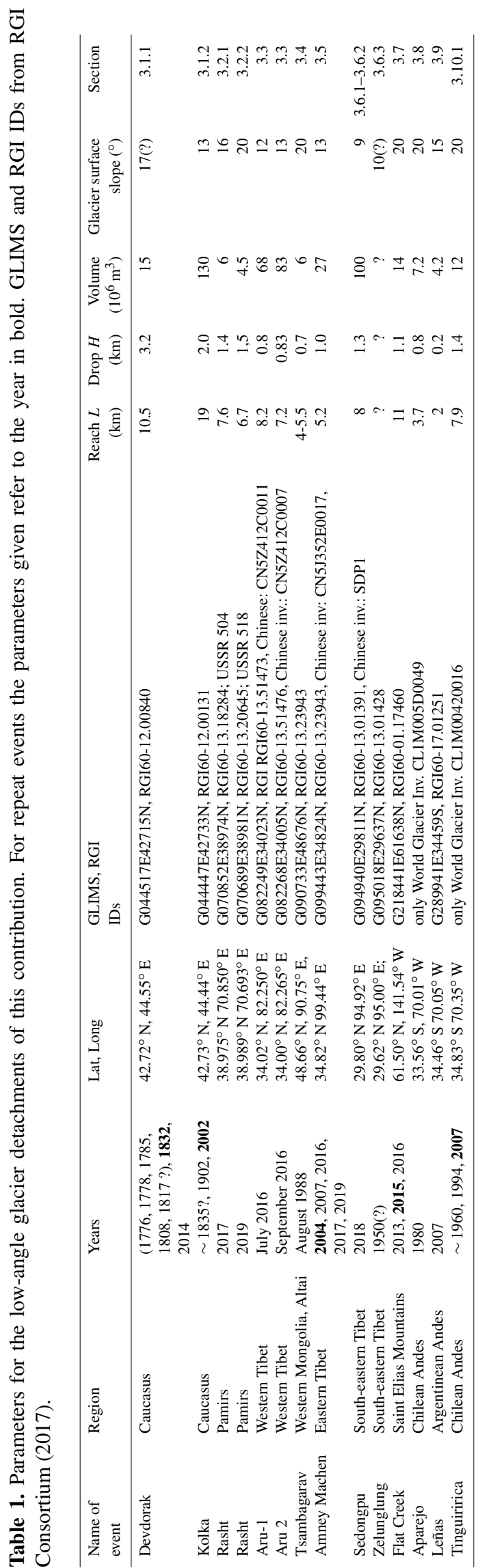




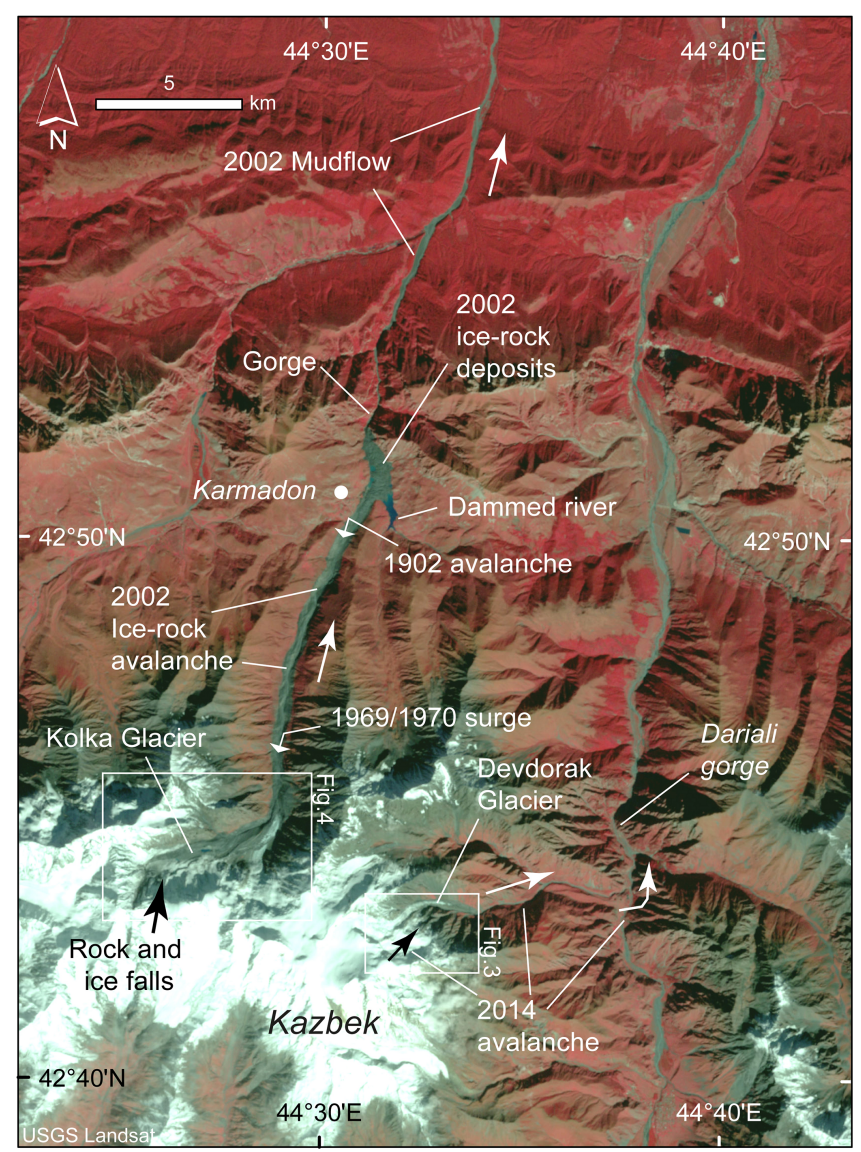

Figure 2. Overview over Mount Kazbek, Russia/Georgia, Caucasus Mountains, with elements of the 2002 Kolka-Karmadon and 2014 Devdorak ice-rock avalanches indicated. Satellite image: Landsat, 6 October 2002 (credit: USGS).

trial photos all indicate highly erodible rock and an abundance of fine sediments at many places on Mount Kazbek. In all high-resolution satellite images available since around 2002 (GoogleEarth, Bing Maps, Maxar, Pleiades), Devdorak Glacier appears heavily crevassed and is partly covered by fine sediments, likely deposited by mass movements from the surrounding mountain flanks. Since 2015, a glacier directly south of Devdorak Glacier has been overriding the main tongue of Devdorak glacier in a surge-like destabilization, perhaps triggered by the 2014 Kazbek/Devdorak icerock avalanche that overran it (Fig. 3). Possibly as a consequence of the tributary surge, Devdorak Glacier itself is currently also advancing (Dokukin et al., 2020). A $1 \mathrm{~km}$ global permafrost model (Obu et al., 2019) not particularly tuned for mountain permafrost indicates the elevation of the Devdorak Glacier tongue is roughly at or below today's lower boundary of the discontinuous permafrost zone in the region.

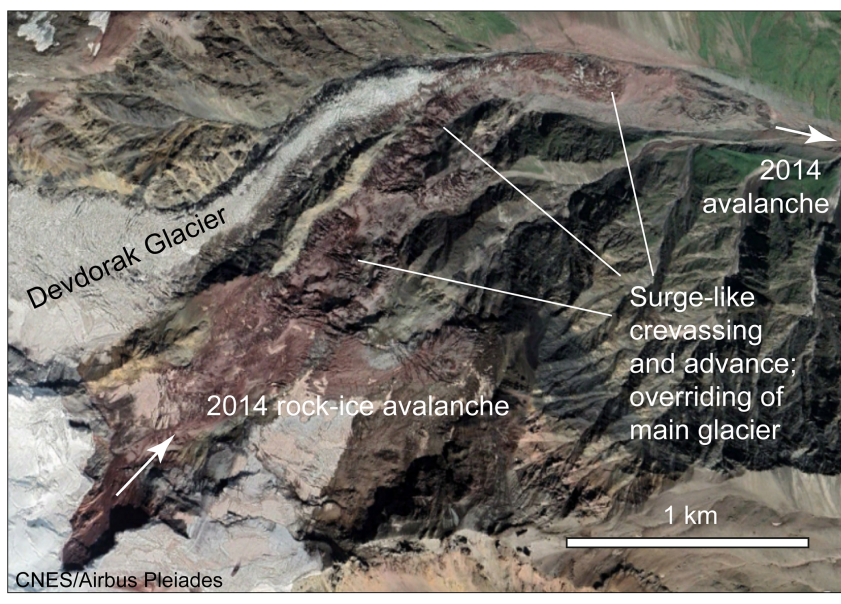

Figure 3. Lower part of Devdorak Glacier and north-eastern flank of Mount Kazbek. The position of the image section is indicated in Fig. 2. Satellite image: Pleiades, (c) Airbus, 19 August 2019.

\subsubsection{Kolka, 1902 and 2002}

The $130 \times 10^{6} \mathrm{~m}^{3}$ Kolka Glacier detachment (Figs. 2 and 4; Table 1) of 20 September 2002 has been described and discussed in several studies (Kääb et al., 2003; Haeberli et al., 2004; Kotlyakov et al., 2004; Huggel et al., 2005; Drobyshev, 2006; Evans et al., 2009b). During these investigations, it became clear that a similar event must have already happened at least once, at the beginning of July 1902 (and probably also around 1700), whereby the glacier tongue detached after a roughly 2 -week-long surge-like advance. Heavy rain and snowmelt may have played a role in triggering the 1902 advance. Damming or erosion by water could then have caused the actual detachment and subsequent rock, mud, and/or ice flow (Drobyshev, 2006; Petrakov et al., 2008; Kotlyakov et al., 2010b). The descriptions given in these references and their sources clearly describe an event that qualifies as a detachment in the sense of the present contribution. The glacier started surging again in autumn 1968 and advanced by $4 \mathrm{~km}$ with speeds of up to $220 \mathrm{~m} \mathrm{~d}^{-1}$ (Fig. 4) but without catastrophic consequences (Hoinkes, 1972; Rototayev et al., 1983). We do not know which differences in conditions, compared to 1902 and 2002, caused the glacier to not detach in 1970. Several other glaciers in the Caucasus are known to have surged in the past (Kotlyakov et al., 2010b). We found that Kolka Glacier had a low surface slope of around $13^{\circ}$ prior to the 2002 detachment. Evans et al. (2009b) estimated a bed slope of $9^{\circ}$ after the detachment. Over the course of several weeks before the 2002 detachment, perhaps triggered by earthquakes (Kotlyakov et al., 2004), heavy rock and ice falls from the northern flank of the Kazbek massif deposited several $10^{6} \mathrm{~m}^{3}$ of material on the glacier. During this period of mass-wasting activity, the glacier changed in unusual ways: it bulged and became heavily crevassed (Fig. 4), it developed a scarp at the location of the later detachment, and 
supraglacial ponds formed (Kotlyakov et al., 2004, 2010b; Evans et al., 2009b). Unusually high geothermal heat fluxes underneath the glacier (fumaroles and a sulfur smell were reported from the glacier bed shortly after detachment), the impact energy of a large rock and/or ice fall and successive loss of shear stress due to excess water pressure have been proposed as possible factors and ultimate triggers of the 2002 detachment (Kotlyakov et al., 2004, 2010b; Evans et al., 2009b). Similarly, the additional loading of Kolka Glacier from the rock and ice falls has more recently been proposed to have increased the basal shear stress until it exceeded a frictional threshold given by the glacier bed material, topography, and hydraulic conditions (Kääb et al., 2018). After the detachment, lakes were visible on the Kolka Glacier bed, pointing to the involvement of large amounts of subglacial water in the detachment. The high mean avalanche velocities of 50-80 $\mathrm{m} \mathrm{s}^{-1}$ (Huggel et al., 2005) suggest the availability of large amounts of water and/or saturated fine-grained till.

The Kolka Glacier tongue is, like Devdorak Glacier, roughly at the lower elevation of the regional discontinuous permafrost zone, and the glacier must have been temperate throughout, except for the likely polythermal or even cold steep hanging glaciers avalanching from the northern flank of the Kazbek massif onto its surface. The ice-rock avalanche resulting from the 2002 detachment is described in detail in the above literature about the event, but we want to draw attention to the streamlined debris stripes, in the following called debris stripes, that were visible in the detachment zone after the event (Fig. 4d; Petrakov et al., 2004; Huggel et al., 2005) because similar patterns have also been found in several of the other cases of this study. Currently, the detached glacier depression is refilling and the glacier is gaining mass again. The fast recovery of the glacier volume lost by the 1970 surge, and again after the 2002 detachment, is associated with Kolka Glacier's positive mass balance, which stands in stark contrast to the predominant strong glacier shrinkage in the Caucasus Mountains (Kutuzov et al., 2019; Zemp et al., 2019). Kolka Glacier had already reached almost $50 \%$ of its pre-detachment volume by 2017 (Supplement Fig. S2) and is projected to accumulate $60 \%-70 \%$ of its pre-detachment volume by 2025 (Petrakov et al., 2018; Aristov et al., 2019).

\subsection{Rasht, Pamir/Tajikistan}

In 2017 and 2019, two glacier detachment events happened on the north side of the Peter the First Range (or Petra Pervogo Range or Peter the Great Range) in the Pamir Mountains of Tajikistan. The resulting masses of both events travelled north into the Rasht Valley through which the Surkhob River flows that later forms the Vakhsh River (Fig. 5).

\subsubsection{Event of 2017}

The 2017 event, first mentioned in Dokukin et al. (2019), happened between 10 and 11 July 2017 (Planet images). A glacier of roughly $1000 \mathrm{~m}$ length and $240 \mathrm{~m}$ width detached (upper scarp ca. at $3600 \mathrm{~m}$ a.s.l.), and the resulting ice-rock avalanche flowed down a narrow valley towards the village of Tojikobod in the Rasht Valley (Figs. 5 and 6; Table 1). In satellite imagery taken shortly after the event (Planet, Maxar), ice remains can be recognized over a horizontal distance of about $8 \mathrm{~km}$, down to an elevation of about $2160 \mathrm{~m}$ a.s.l. Beyond this point, a considerable debris and/or mud flow must have continued for another $2 \mathrm{~km}$ or so. The detached glacier had a surface slope of around $16^{\circ}$ (High Mountain Asia digital elevation model, DEM; Shean, 2017). We measured increased surface speeds of up to $5.8 \mathrm{~m} \mathrm{~d}^{-1}$ in early July 2017 (compared to a few decimetres per day, $\mathrm{dm} \mathrm{d}^{-1}$, in 2016; velocities from repeat Planet data) and detected unusual lateral crevasses delineating the later detachment area in images from as early as May 2017 (Fig. 6). The glacier is likely not surrounded by permafrost (Obu et al., 2019).

To roughly estimate the event volume, we derive the ice thickness along the centre flow line of the glacier based on an estimated basal shear assuming a driving stress of $1.2 \times 10^{5} \mathrm{~Pa}$ as suggested for mountain glaciers, a slope of $16^{\circ}$, and a form factor of 0.8 , which then results in a thickness of around $60 \mathrm{~m}$ (Cuffey and Patterson, 2010). Multiplying half of this depth (i.e. assuming a triangular cross section) with the detached area (ca. $200000 \mathrm{~m}^{2}$ ) gives a first volume estimate of roughly $6 \times 10^{6} \mathrm{~m}^{3}$. Whereas satellite images after detachment suggest that much of the glacier bed might actually have a triangular cross section, it may have been more shallow in the lowermost and uppermost parts. As an order of magnitude, we suggest a detachment volume of $5 \times 10^{6} \mathrm{~m}^{3}$ and assign a conservative error of $\pm 1 \times 10^{6} \mathrm{~m}^{3}$ to this estimate.

The cirque from which the 2017 event originated was also the source of other slope instabilities over recent years. Another (much smaller) ice-rock avalanche from a neighbouring glacier occurred between 15 and 24 July 2016 (dates from Planet images), with a horizontal reach of roughly $5.5 \mathrm{~km}$. A large debris flow descended the same valley in late $\mathrm{Au}$ gust 2016, starting from the same cirque, likely entraining deposits of the July 2016 avalanche and reaching the Surkhob River $19.4 \mathrm{~km}$ downstream where it destroyed several buildings, bridges, and agricultural fields.

\subsubsection{Event of 2019}

Between 2 and 3 August 2019 a second glacier, ca. $14 \mathrm{~km}$ to the west of the one that collapsed in 2017, detached (Figs. 5, 7). This glacier was slightly smaller than the 2017 one and had a surface slope of around $20^{\circ}$. The resulting ice-rock avalanche travelled north down a narrow valley to- 

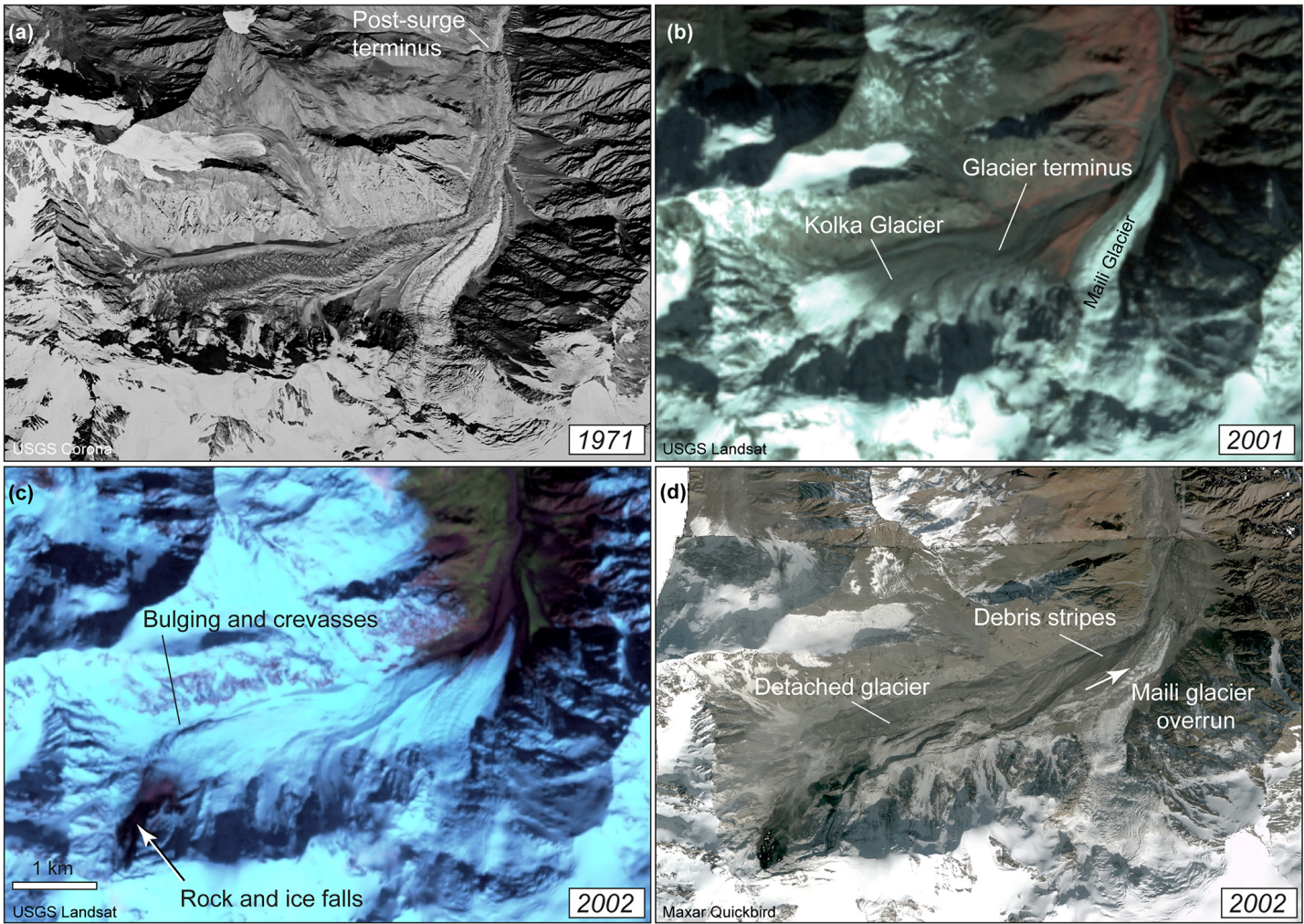

Figure 4. Kolka Glacier, Mount Kazbek. (a) Kolka Glacier surged in 1969/70. Satellite image: Corona, 20 September 1971 (credit: USGS). (b) Landsat image, 3 October 2001 (credit: USGS). (c) Days and weeks before the 2002 detachment, rock and ice falls or avalanches were observed on the glacier, and the left lateral margin of the glacier was bulged and heavily crevassed. Satellite image: Landsat, 20 September 2002, a few hours before detachment (credit: USGS). (d) QuickBird satellite image ( Maxar), 25 September 2002, 5 d after detachment. The position of the image sections is indicated in Fig. 2. The location of debris stripes in avalanche direction is indicated.

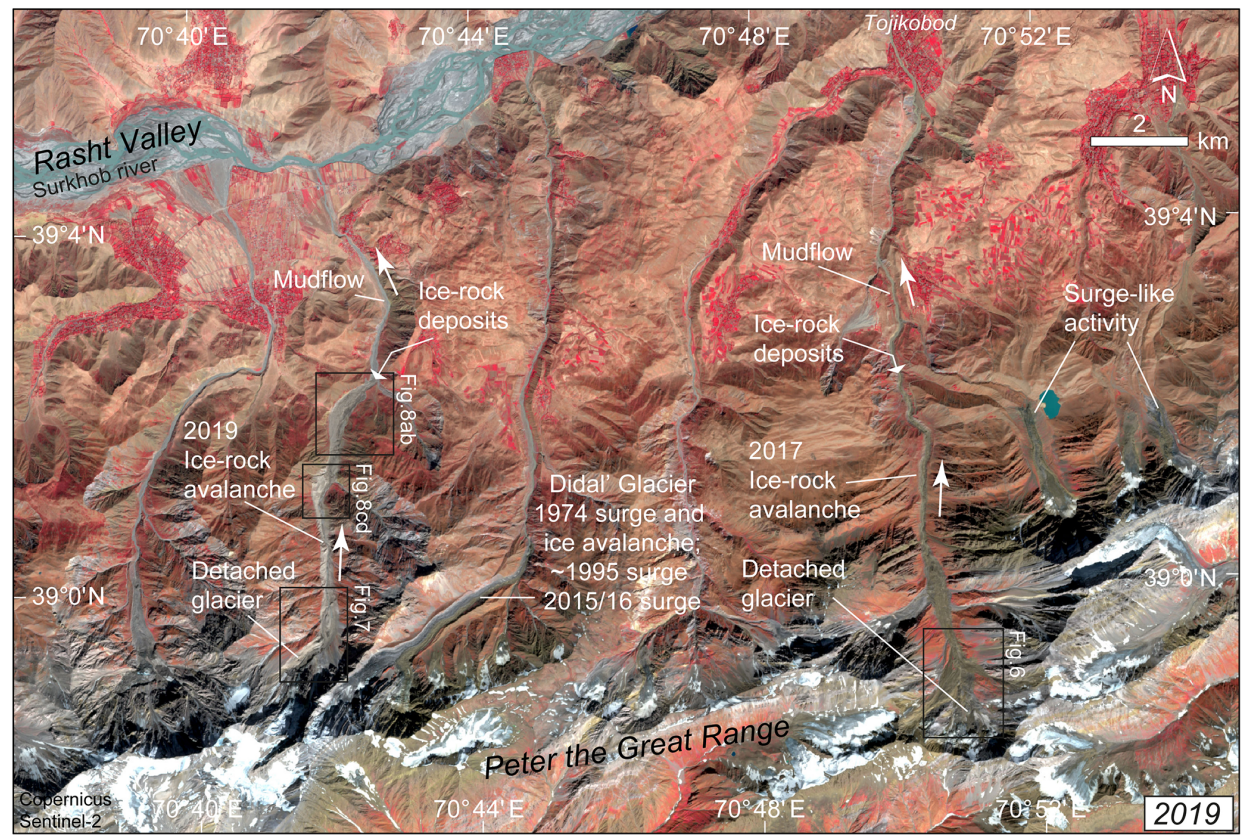

Figure 5. Rasht Valley and Peter the Great Range, Tajikistan. Locations of the 2017 and 2019 ice-rock avalanches are indicated. Satellite image: Sentinel-2, 19 September 2019 (credit: Copernicus Sentinel data). 

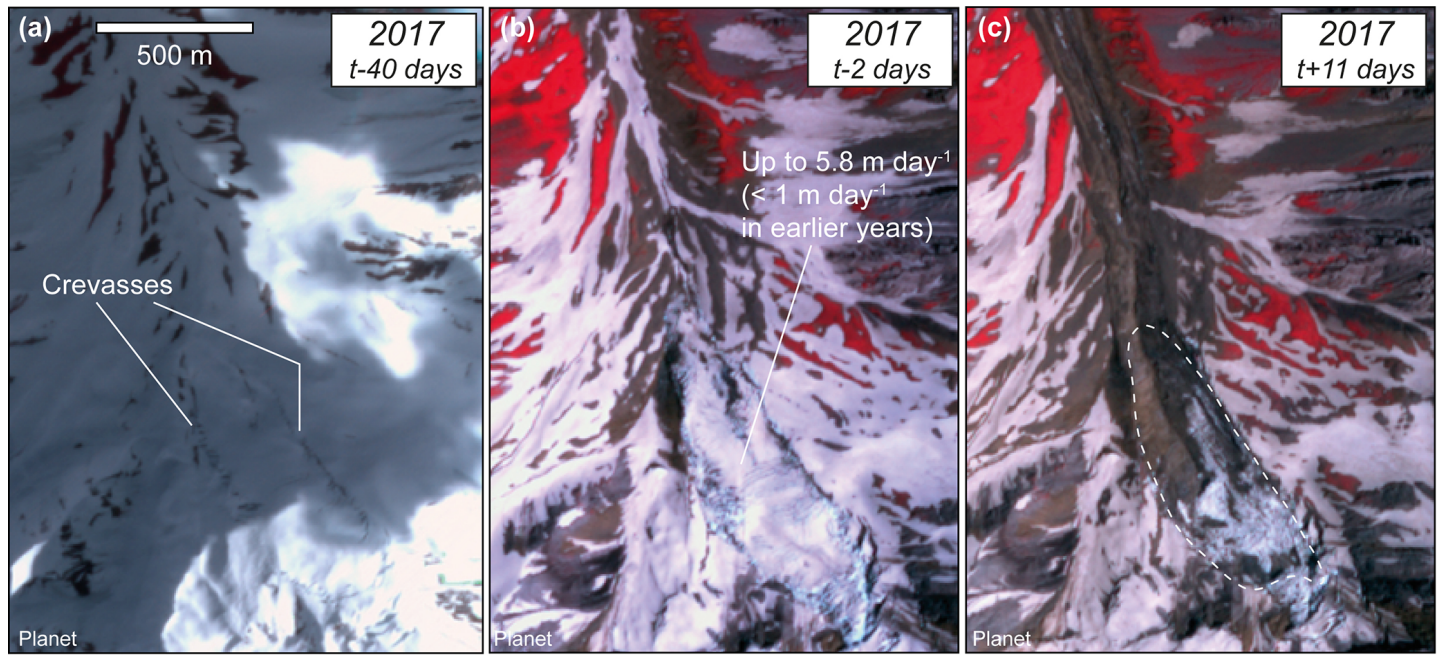

Figure 6. Planet images over the Rasht Valley glacier detachment of around 10 July 2017 (=t). (a) 31 May 2017, (b) 8 July 2017, and (c) 21 July 2017. Abnormal marginal crevassing and enhanced speeds were visible several weeks before the detachment. See Fig. 5 for location. (Satellite images (C) Planet.)

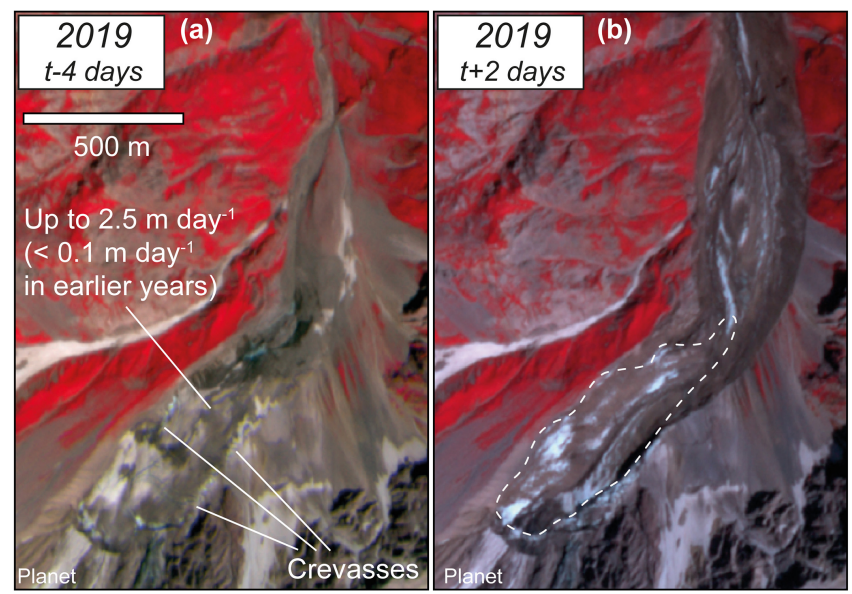

Figure 7. Planet images over the Rasht Valley glacier detachment of around 2 August 2019 (=t). (a) 29 July 2019 and (b) 4 August 2019. See Fig. 5 for location. (Satellite images (C) Planet.)

wards the Rasht Valley over a horizontal reach of $6.5 \mathrm{~km}$ and a vertical drop from 3350 (upper scarp) to $1850 \mathrm{~m}$ a.s.1. Superelevations of the ice-rock avalanche path of up to almost $200 \mathrm{~m}$ above the valley bottom suggest high avalanche speeds (McClung, 2001). We estimated the detached volume in the same way as described for the 2017 event (Sect. 3.2.1) and computed a volume of $4.5 \pm 1 \times 10^{6} \mathrm{~m}^{3}$ (glacier area ca. $230000 \mathrm{~m}^{2}$; centreline depth $50 \mathrm{~m}$ ). Based on pre- and postevent WorldView stereo DEMs, Leinss et al. (2020) estimate a maximum erosion depth of $90 \mathrm{~m}$ and a detachment volume of $8-9 \times 10^{6} \mathrm{~m}^{3}$, i.e. significantly more than our rough general model.

This glacier also showed increased sliding speeds and crevassing around the later detachment area for at least 2-
3 weeks before the failure. For the end of July 2019 we found surface speeds of roughly $2.5 \mathrm{~m} \mathrm{~d}^{-1}$, a marked increase compared to roughly $<0.1 \mathrm{~m} \mathrm{~d}^{-1}$ during 2017-2018 (repeat Planet data). The glacier did not show any visual signs of destabilization between 2015 and 2018 (Planet images). In 2007 (Maxar; see Supplement Fig. S3) the glacier looked heavily crevassed, possibly an indication of a surge-like advance. This condition is still visible in Landsat data 5-6 years later, though less certain due to the lower resolution of Landsat data (no other data are available to us between 2007 and 2015). Landsat data also suggest that the glacier experienced a similar advance in the early 1990s. Under the limitation of the reduced spatial resolution of the Landsat data, however, we do not find signs of a large detachment event or large ice-rock avalanche. Nevertheless, we draw attention to a surprisingly vegetation-free landform visible downstream of the 2019 detachment in pre-event imagery (Fig. 8). The lack of vegetation, the streamlined microtopography, and zones of rough and chaotic microtopography that resemble avalanche or debris flow deposits (Fig. 8; Supplement Fig. S4) led us already before the 2019 event to interpret this landform as a possible geomorphological imprint of an earlier ice-rock avalanche (Kääb, 2019). Meanwhile, this landform has been overrun by the August 2019 ice-rock avalanche, leaving similar new forms, and suggesting that the landform now buried could have originated from a similar detachment event, probably before 1961 (year of earliest Corona satellite image). Between the 1961 Corona images and very high-resolution images from just before the 2019 avalanche, no significant changes are visible on the landform.

Very high-resolution satellite images over the Peter the First Range suggest an abundance of weak bedrock and fine sediments. All over the range, signs of large debris flows, 

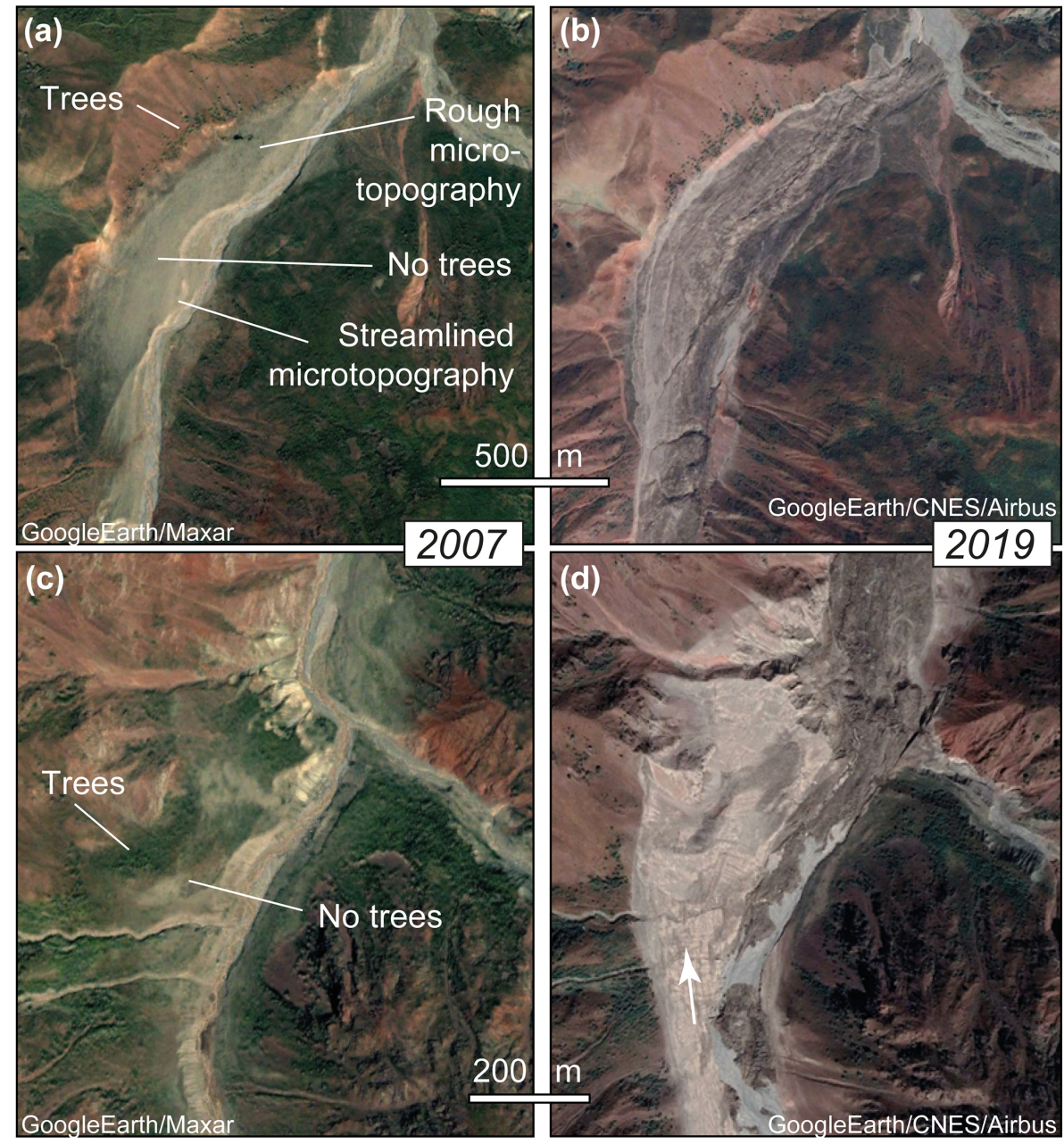

Figure 8. Location of the $\sim 2$ August 2019 Rasht Valley ice-rock avalanche. See Fig. 5 for image location. (a, c) 30 July 2007 (C) Google Earth and Maxar). (b, d) 20 August 2019 (@ Google Earth and CNES/Airbus). Before the 2019 event, traces of a potential former large mass flow were visible (lack of trees in the valley, sparse vegetation, debris stripes).

rock avalanches, or ice-rock avalanches are visible in highresolution satellite images (Maxar, CNES/Airbus, Planet; Leinss et al., 2020). The Pamirs are known to be very geomorphologically active, with a number of associated hazards (Mergili et al., 2012; Gruber and Mergili, 2013; Strom and Abdrakhmatov, 2018) and a cluster of surge-type glaciers (Kotlyakov et al., 2008, 2010a; Gardelle et al., 2013; Sevestre and Benn, 2015; Lv et al., 2019; Goerlich et al., 2020). A number of glaciers in the Peter the Great Range were surging at the time of writing or have done so in the recent past (Fig. 5). Didal Glacier (ca. $12^{\circ}$ steep) surged around 1995 and again during the winter 2015/16 when it advanced by $2.5 \mathrm{~km}$ over a few months. In the valley below Didal Glacier we note a lack of vegetation in the valley and landforms that could well stem from a former ice-rock avalanche. Kotlyakov et al. (2010a) mention a $2.2 \mathrm{~km}$ long ice avalanche from Didal Glacier in 1974. In comparison, the bottom of the valley through which the 2017 ice-rock avalanche descended
(Sect. 3.2.1) was partly tree covered before, suggesting that no event like the 2017 one has happened there in the recent past.

Even if not documented in detail in an internationally accessible format so far, to our best knowledge, both the 2017 and 2019 detachments and their downstream effects were very likely noted by the local communities as the lowermost ice and rock deposits stopped not far from settlements, agricultural fields, and pastures, and very high-resolution images (Maxar) show that flooding happened close to houses, and two irrigation channel bridges were partially destroyed.

\subsection{Aru, 2016, western Tibet}

On 17 July 2016, a massive volume of glacier ice detached from the lower part of an unnamed glacier in the Aru range (Rutok County, China) in the western Tibetan Plateau (termed Aru-1). The fragmented ice mass ran out $6 \mathrm{~km}$ beyond the glacier terminus, killing nine herders and hundreds 
of their animals, and reached the Aru Co lake (Tian et al., 2017; Kääb et al., 2018). The ice debris covered $8-9 \mathrm{~km}^{2}$, and a volume of $68 \times 10^{6} \mathrm{~m}^{3}$ was calculated for the detached glacier part. On 21 September 2016, a second glacier (Aru-2) detached just a few kilometres south of Aru-1 (Fig. 9). Similar to the July event, the glacier ice fragmented and transformed into a mass flow. The glacier debris in the second detachment covered $6-7 \mathrm{~km}^{2}$ with a detached glacier volume of $83 \times 10^{6} \mathrm{~m}^{3}$. The maximum glacier thicknesses that detached were around $115 \mathrm{~m}$ (Aru-1) and $145 \mathrm{~m}$ (Aru-2), and maximum deposit thicknesses were around $25 \mathrm{~m}$ (Aru-1) and $80 \mathrm{~m}$ (Aru-2) (Kääb et al., 2018). The mean speeds of the Aru ice-rock avalanches were estimated to be $30-50 \mathrm{~m} \mathrm{~s}^{-1}$ with maximum speeds of 70-90 $\mathrm{m} \mathrm{s}^{-1}$ (Kääb et al., 2018). (For a satellite image of the current situation of the Aru glaciers and the deposits, see the Supplement Fig. S5.)

Glaciers in the wider region around the Aru range are part of the Karakoram-western Kunlun Shan-eastern Pamir anomaly (Treichler et al., 2019) and experienced a slight increase in thickness of around $0.20-0.30 \mathrm{~m} \mathrm{a}^{-1}$ water equivalent since the early 2000s (Brun et al., 2017; Kääb et al., 2018). Positive mass balances of the Aru glaciers (modelled based on ERA-interim reanalysis data; Kääb et al., 2018) and the widespread growth of endorheic lakes confirmed a precipitation increase in the region since the late 1990s (Treichler et al., 2019). Driven by these positive mass balances, the two Aru glaciers underwent surge-like accelerations and mass transfers over several years before the detachments (Gilbert et al., 2018; Kääb et al., 2018). In apparent contrast to the positive mass balances and the surge-like mass transfers, the Aru- 1 and Aru-2 glaciers both retreated by around $500 \mathrm{~m}$ between 1970 and 2015 .

Since at least 2011 and until 2014, the sections above the eventual detachment zones of both Aru glaciers subsided. Simultaneously, glacier sections below bulged upwards. The rates of elevation change derived for 2011-2014 indicate that a down-glacier mass transfer had already begun during the second half of the 2000s (Gilbert et al., 2018). A modelling study based on the observed elevation changes reconstructed changes in basal friction and horizontal velocity prior to the detachments (Gilbert et al., 2018). It showed that the two glaciers were close to their steady state geometry with no or little sliding until 2010. Thereafter, decreasing friction under the whole detachment area of Aru- 1 and in more localized zones of Aru-2 started to trigger the surge-like mass transfer. Modelling the glaciers' thermal regimes revealed that the frictional changes likely occurred in temperate areas of the two glaciers and that stress concentration occurred at the cold-ice margins (Gilbert et al., 2018). The surge-like changes in basal friction under the Aru glaciers were thus likely not associated with a change in the glaciers' thermal regimes but rather with a change in friction due to increasing water pressure in the already temperate areas. However, comparing centennial-scale climate changes, for example the Little Ice Age to the 2000s, it is likely that the late 20th century climate would have moderated a former severe permafrost condition and created conditions whereby a polythermal structure and a temperate part of the glacier could exist, thus allowing the conditions that resulted in the detachments. During the instability development, basal shear stresses in the detachment area dropped by an order of magnitude, leading to significant stress concentrations at the detachment margins and in a few spots under the glaciers. These stress concentrations led to strongly enhanced crevassing at the glacier margins and the zone of the later scarp head several months prior to the Aru-1 detachments. Fastdeveloping crevasses appeared only 3 weeks before the Aru2 detachment and were discovered in satellite images in time to alert Chinese authorities.

The Aru glaciers are surrounded by continuous permafrost of -3 to $-4^{\circ} \mathrm{C}$ mean annual ground temperature (Obu et al., 2019). Field observations in the detachment and runout zones showed no presence of a hard-bed lithology beneath the glaciers, and very few large boulders were observed in the runout paths (own field visit and Lei et al., 2021). Rather, extensive deposits of soft, unconsolidated, and fine-grained lithologies were identified. The Aru glaciers, situated in a region of positive or zero mass balances (Brun et al., 2017; Treichler et al., 2019), could well build up again to a size similar to the one before their 2016 collapses. Especially in the path of the Aru-1 avalanche, streamlined debris stripes, not present before the event, are well visible at several locations in high-resolution satellite data (Supplement Fig. S6). We find no other evidence for a similar event in the recent past at the site, so finding two similar events at neighbouring glaciers is rather remarkable.

\subsection{Tsambagarav, 1988, Altai, western Mongolia}

Information about the 1988 Tsambagarav event is mainly relying on observations and interpretations by Avdeev et al. (1989). On the evening of 9 August 1988 (local time), the lower part of an unnamed glacier on the southern flank of Tsambagarav mountain (4193 m a.s.1.), Altai mountains, western Mongolia, detached and formed an ice-rock avalanche. The avalanche travelled about $5.5 \mathrm{~km}$ (Avdeev et al., 1989), and from Landsat data we suggest the last 1$2 \mathrm{~km}$ might have been a mud flow (Fig. 10). As a peculiarity of this event, it seems to have been preconditioned by the 23 July 1988 Tsambagarav M6.4 earthquake. As a consequence of this earthquake, a large block (ca. $6 \times 10^{6} \mathrm{~m}^{3}$ ) of the lower part of the glacier was separated from its upper parts and displaced a few metres in the south-eastern direction. Melt water could then reach the glacier bed beneath the ice block through the developing crack. On $9 \mathrm{Au}-$ gust 1988, the ice block detached from the glacier bed. Avdeev et al. (1989) describe the path of the resulting icerock avalanche in detail, but here we want to highlight two aspects of it. First, after about $1.8 \mathrm{~km}$, the avalanche jumped (obviously at high speeds) over a $70 \mathrm{~m}$ tall ridge, leaving 

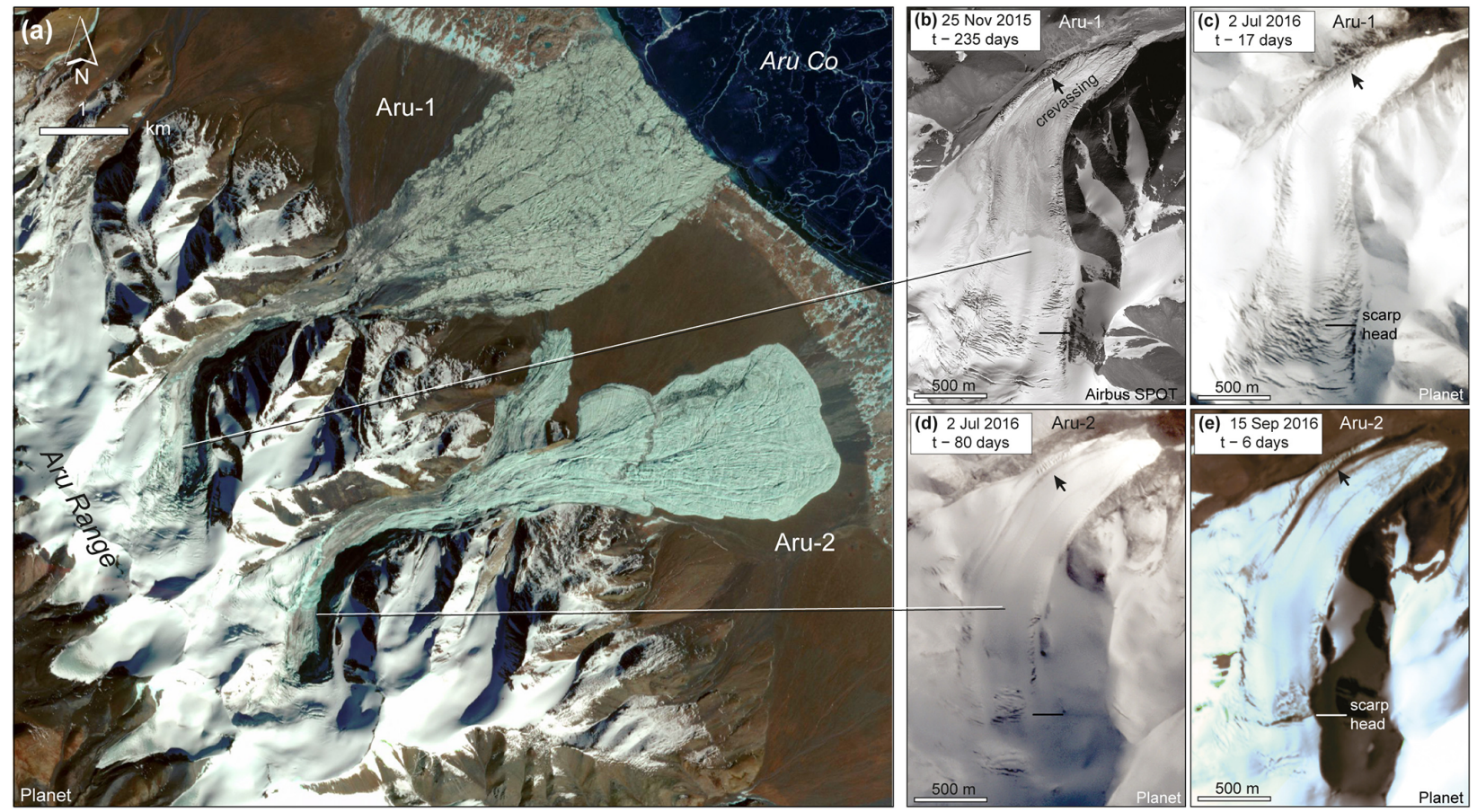

Figure 9. Satellite images of the Aru glaciers, western Tibet, and their detachments. (a) Planet infrared false-colour satellite image of 29 November 2016 after both glaciers collapsed (@ Planet). (b) Enhanced crevassing on Aru-1 glacier (SPOT7, (CAirbus). Time $t$ refers to detachment date (17 July 2016 for Aru-1, 21 September 2016 for Aru-2). Note the particular crevassing at the northern curve of the glacier. (c) Aru-1 (@ Planet). (d) Aru-2 (SPOT7, () Airbus). (e) Aru-2 (@ Planet), 6 d before collapse. The horizontal line in panels (b)-(e) indicates the scarp head positions of the later detachments.

the ground on the leeward side of the ridge intact. Second, Avdeev et al. (1989) estimate the deposited avalanche volume to be about $12 \times 10^{6} \mathrm{~m}^{3}$ (versus $6 \times 10^{6} \mathrm{~m}^{3}$ detached ice volume) indicating that the detachment must have eroded and ingested substantial amounts of material along the way. The large debris content of the deposits likely also played a role in that it took almost 30 years for the ice content to melt out completely (Agatova et al., 2020).

In a Corona satellite image from 11 August 1968, two obvious transverse crevasses, surrounded by a number of smaller concentric crevasses, can be seen at the location of the upper scarp of the 1988 earthquake-triggered rupture and later glacier detachment (Fig. 10c). The entire feature has a diameter in the order of $150 \mathrm{~m}$. Close visual inspection leads us to interpret the feature as a depression in the glacier surface. From many contemporary Planet satellite images with snow cover and from Landsat 8 thermal data, we do not find indications of enhanced geothermal activity at the depression location. Today, the location appears to be the place for a spring that concentrates the subsurface runoff of the entire cirque. This spring could already have existed in 1988 and led to reduced basal friction and enhanced basal melt at its position and thus to a depression on the glacier surface. Also today's glacier remains show a few obvious crevasses in the same area. Overall, the 1988 detachment seems to have hap- pened at a pre-existing weakness and strongly crevassed location of the glacier.

Avdeev et al. (1989) note a slope angle of the detachment area of 20-25 . From the Shuttle Radar Topography Mission (SRTM) DEM we find a slope of the valley bottom of around $15^{\circ}$ at the location of the detached glacier part and assign an arbitrary $20^{\circ}$ slope to the pre-detachment glacier. Since the detachment in 1988, the entire glacier has shrank substantially, and as of 2020 only a small part of it is left. The detachment site lies in continuous permafrost with mean annual ground temperatures in the order of $-10^{\circ} \mathrm{C}$ (Obu et al., 2019). Avdeev et al. (1989) mention the existence of shattered bedrock in and around the glacier bed, and this is in line with visible interpretations of contemporary high-resolution satellite images. Ultimately, we cannot draw conclusions about the existence of particularly fine-grained sediments at the detachment site. From the weak avalanche traces that are still visible in high-resolution satellite images, it would be difficult to recognize the site as a place of a former glacier detachment and ice-rock avalanche. However, with the information from Avdeev et al., available, one can still detect signs of the past avalanche, such as debris stripes oriented in the avalanche direction and debris deposits inundating the mountain grassland (Fig. 10b). We do not find similar signs in other glacier valleys surrounding Tsambagarav, 


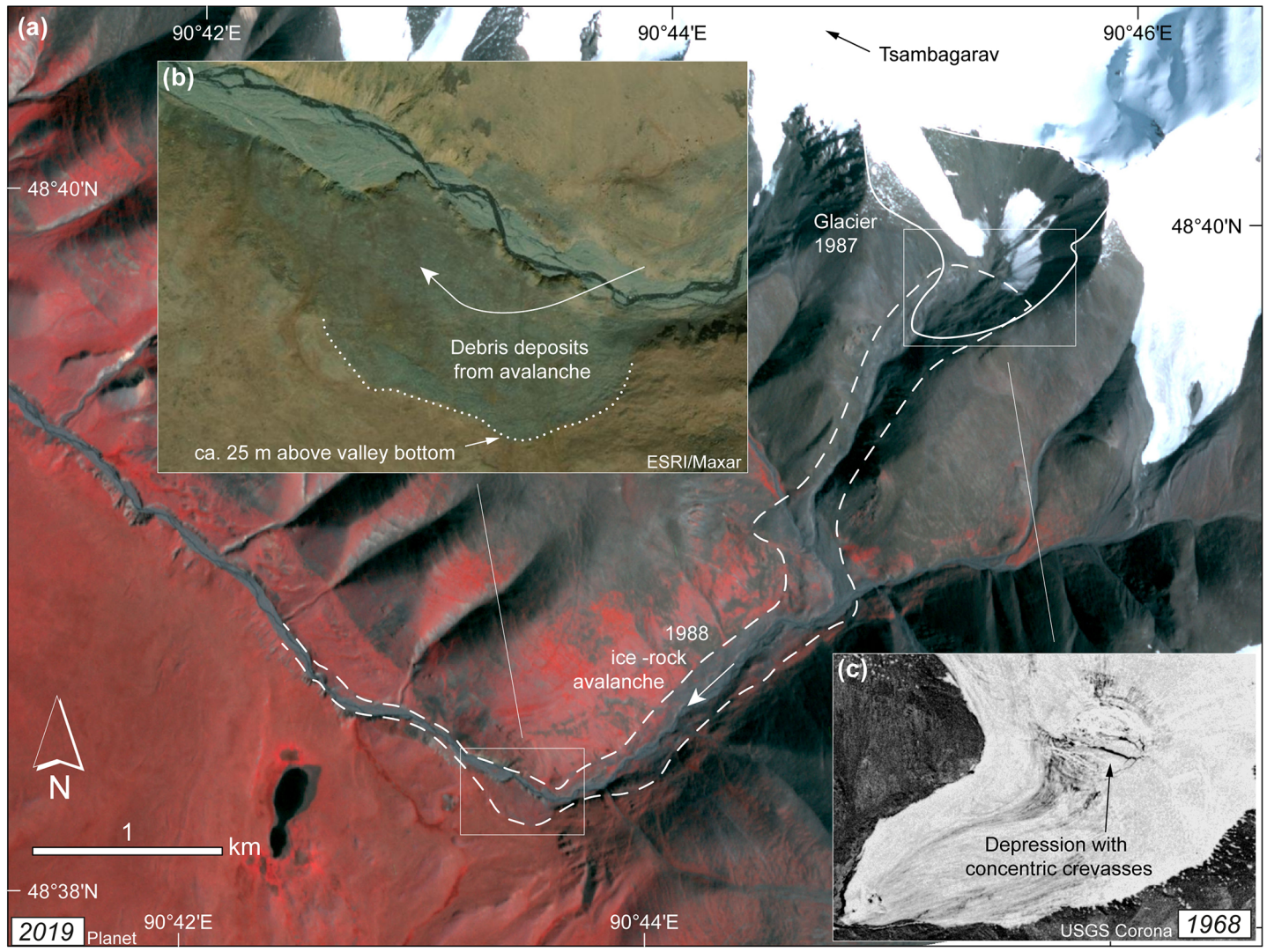

Figure 10. (a) Location of the 9 August 1988 Tsambagarav glacier detachment. Glacier outline of 1987 from Landsat TM indicated by the bold line and rough outline of ice-rock avalanche path from 1989 Landsat data by the dashed line. The white rectangles indicate the positions of panels (b) and (c) (satellite image, 2019, (C Planet). (b) Detail of 2015 WorldView data (@ ESRI/Maxar). The upper elevation of debris deposits from the avalanche in this right turn is about $25 \mathrm{~m}$ above valley bottom. (c) A 11 August 1968 photo from a Corona satellite shows crevasses around a depression on the glacier surface at the location of the upper scarp of the 1988 detachment (credit: USGS).

and the Corona spy satellite image from 11 August 1968 suggests that nothing like this has happened here before. Lastly, we are not aware of recent surge-type activity of glaciers in the Altai.

\subsection{Amney Machen, 2004, 2007, 2016, and 2019, eastern Tibet}

A sequence of surge-like advances, some of them ending in detachments of the glacier tongue, have been observed for a glacier in the Amney Machen mountain range, eastern Tibet (Fig. 11, Table 1; Paul, 2019). The isolated mountain range is home to several surging glaciers (Wenying, 1983). The first ice-rock avalanche happened between 26 January and 3 February 2004, and the involved volume was estimated to be $20-25 \times 10^{6} \mathrm{~m}^{3}$, perhaps up to $36 \times 10^{6} \mathrm{~m}^{3}$ according to a local information sign-board (Paul, 2019). After 3 years, between 23 September and 2 November 2007, a second detachment followed a surge-like recovery of the glacier tongue that had detached in 2004. The 2007 detachment was considerably smaller in volume than the one in 2004. A third detachment, also smaller than that in 2004 , occurred between
4 and 7 October 2016 (date from Planet images). Following this event, the glacier tongue started to recover again, and another small avalanche occurred from it between 9 and 20 July 2019. Paul (2019) notes the weak rocks and fine sediments visible in the rock ribs in the glacier's steep source area. The glacier recovered rapidly after each detachment, suggesting that it is largely nourished by ice and rock fall from the headwall and that a rock and ice melange likely makes up the glacier tongue. The surface slope of the detaching lower part of the glacier is around $15^{\circ}$. The glacier lies in an area of continuous permafrost with ground temperatures in the order of -3 to $-6^{\circ} \mathrm{C}$ (Obu et al., 2019). Debris stripes oriented in the avalanche direction are visible in high-resolution satellite images (not shown).

\subsection{Sedongpu/Gyala, 2018, south-eastern Tibet}

During 2017 and 2018 the Sendongpu basin below the western flank of the Gyala Peri peak (7294 m a.s.1.; Fig. 12) in south-eastern Tibet was the source of a series of large mass flows. Some of them dammed the Yarlung Tsangpo river, which posed a serious flood hazard to the upstream Gyala vil- 

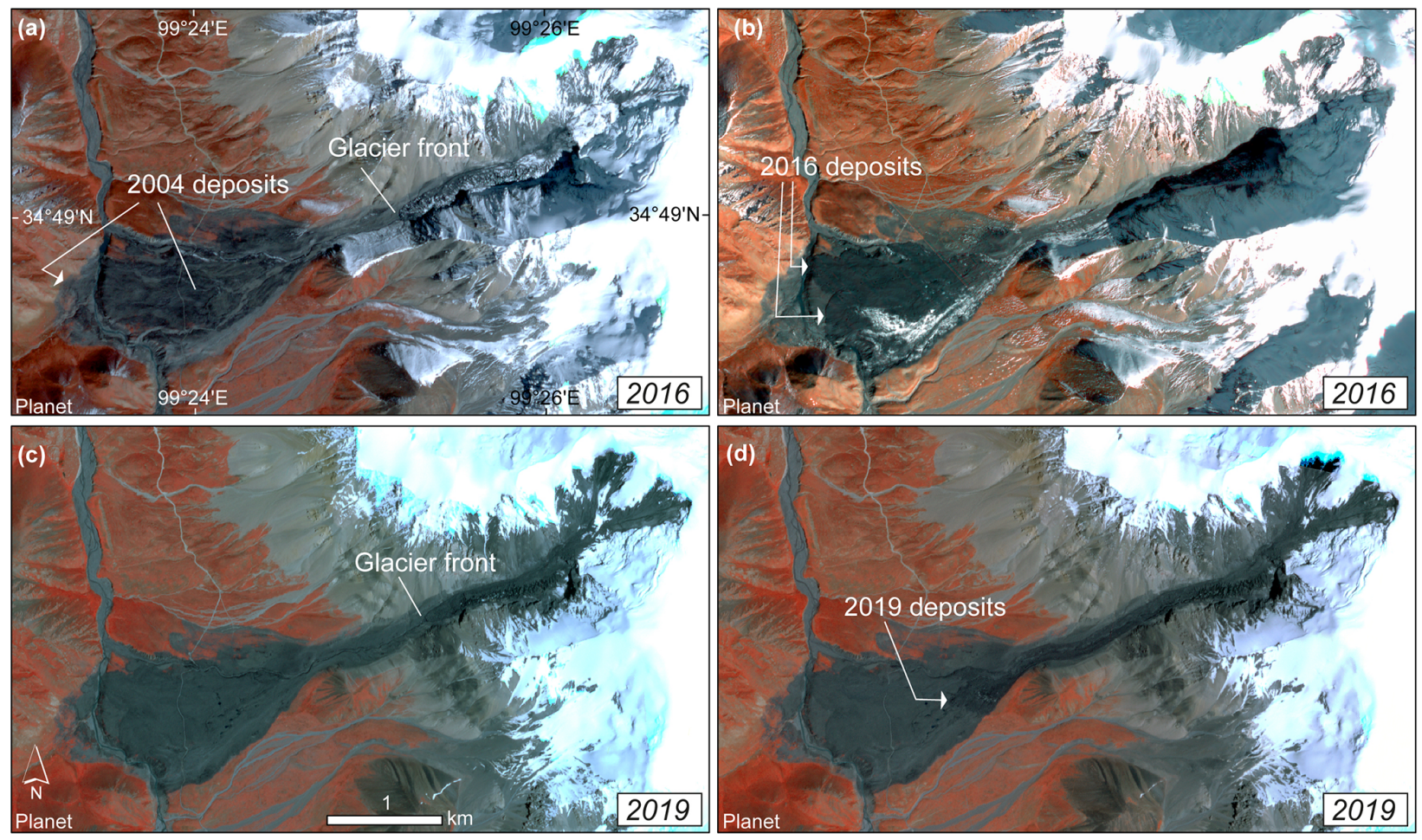

Figure 11. Unnamed glacier in the Amney Machen range, Tibet. Satellite images of (a) 2 October 2016, (b) 23 October 2016, (c) 9 July 2019, and (d) 25 July 2019. Detachments of the glacier tongue happened before (a), between (a) and (b), and between (c) and (d). (Satellite images (C) Planet.)

lage and large downstream areas and triggered hazard management and investigations of the causes (Tong et al., 2018; Liu et al., 2019; Chen et al., 2020). The largest of the mass flows stemmed from the detachment of a large, low-angle glacier in 2018.

\subsubsection{Events before 2018}

In order to elucidate significant elements of the recent massflow history from the basin that might have conditioned the 2018 detachment and that are not documented in detail elsewhere, we start our description with the oldest satellite data available to us. In Corona satellite reconnaissance data of 8 December 1969, a narrowing in the Yarlung Tsangpo river where the Sendongpu valley joins the river points to deposits from previous mass flows. However, trees on these deposits suggest no recent large mass flow activity. The main glacier in the basin, here called Sedongpu Glacier (Fig. 12), shows some signs of enhanced flow such as large crevasses. In Corona satellite data of 6 November 1974, the glacier has advanced some $800 \mathrm{~m}$ into steeper terrain. Fresh traces of a large mass flow are visible between the glacier front and the main Yarlung Tsangpo river, and fresh deposits seem to have covered or destroyed the forest on the older deposits in the river, but the main glacier is still in place. The glacier showed one single tongue in 1969 but had split into two tongues dur- ing its advance by 1974 , a feature that it still exhibited in 2016. Chen et al. (2020) describe an ice avalanche from the Sedongpu basin that dammed the Yarlung Tsangpo river in 1968 but do not mention any other events before 2014. From our interpretation of the Corona satellite data there was either one more event between 1969 and 1974, or the event dated "1968" actually happened a few years later. The next large mass flow (listed as ice avalanche in Chen et al., 2020, and debris flow in Tong et al., 2018; we interpret at least a large debris content) happened in 2014. The source of the mass flow must have been in the upper part of the main Sedongpu Glacier or its headwall as both lateral moraines of the glacier were heavily eroded from the glacier side (RapidEye satellite data of 2013-2015). The glacier surface was not visibly changed along the glacier centre line, suggesting that the mass flow must have flowed along both glacier margins. Although difficult to determine in the satellite data available to us, the flow may have eroded the lowermost part of the glacier tongue.

Between 20 and 27 October 2017 (Planet and Sentinel2 images) a huge rock avalanche started high up from the north ridge of Gyala Peri and ran over large parts of the Sedongpu basin and down to Yarlung Tsangpo, damming the river (Figs. 12 and 13). The event seems to have had a severe impact on Sedongpu Glacier. We generated two elevation models from 13 November 2015 Spot6 and 30 Decem- 


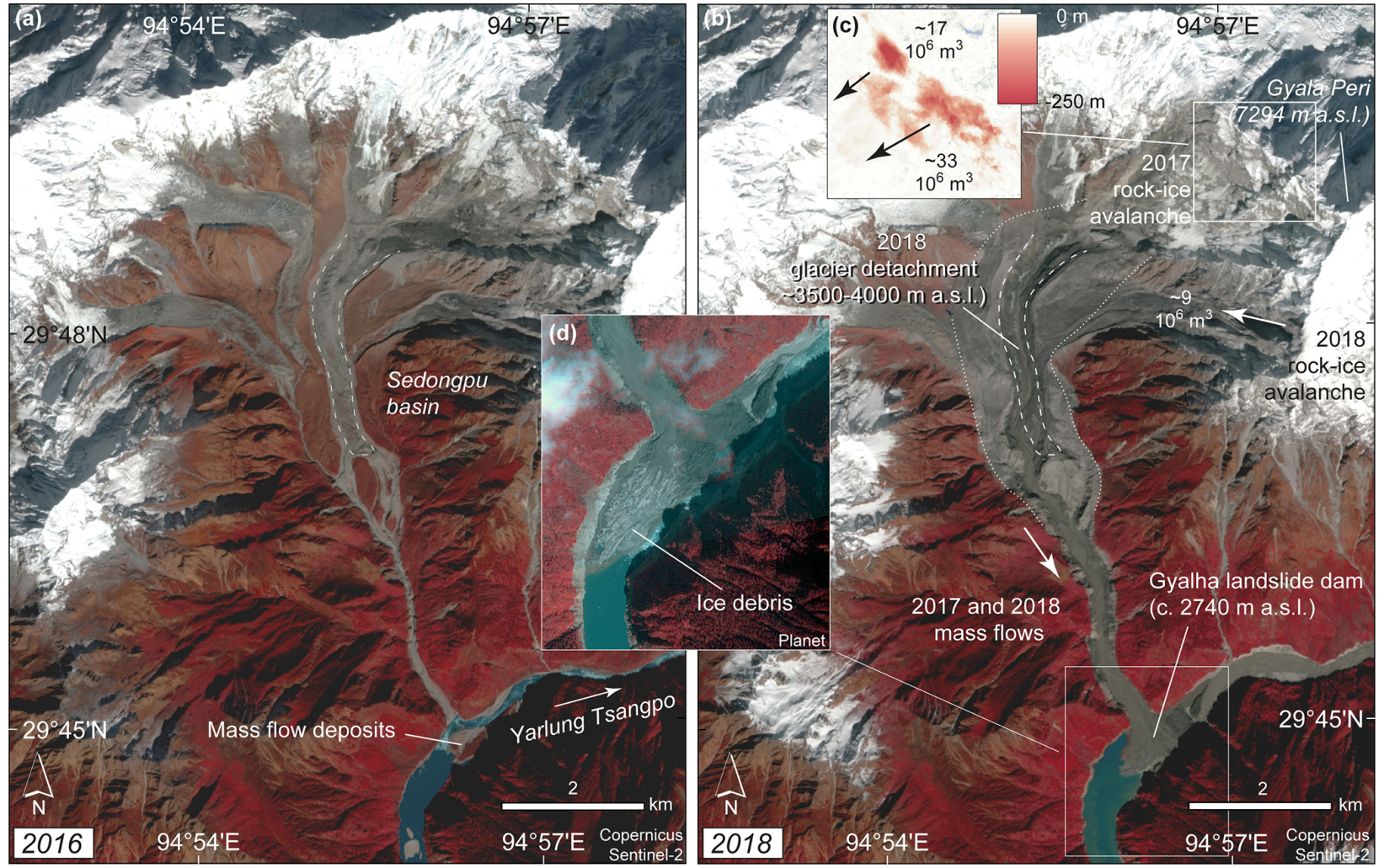

Figure 12. Location of the 17/18 October 2018 Sedongpu Glacier detachment, south-eastern Tibet. (a) Sentinel-2 image of 20 November 2016 (credit: Copernicus Sentinel data) before a series of mass flows happened that culminated in glacier detachment. Already earlier, mass flows from the basin have blocked the Yarlung Tsangpo river. (b) Sentinel-2 image of 31 October 2018 showing the area impacted by the 22 October 2017 rock avalanche from the Gyala Peri peak and the 17/18 October 2018 glacier detachment. (c) Detail of elevation model differences between SPOT6 13 November 2015 and Pleiades 30 December 2018 tri-stereo data. Elevation losses amount up to 330 m, but the colour scale is saturated at $-250 \mathrm{~m}$. (d) Detail of the glacier detachment deposits in the main river (CPlanet; image of 27 October $2018,10 \mathrm{~d}$ after detachment).

ber 2018 Pleiades tri-stereo data that produced robust results despite the extreme topographic conditions. Differencing the two DEMs indicates that the October 2017 rock avalanche removed around 17 and $33 \times 10^{6} \mathrm{~m}^{3}$ of material from two close-by but separated areas, respectively (Fig. 12c). If both failures happened as part of the same event, the total volume of $50 \times 10^{6} \mathrm{~m}^{3}$ makes this one of the larger rock avalanches detected in recent decades. Based on a visual inspection of satellite data, we consider it very likely that the avalanche also involved small glaciers from the west wall of Gyala Peri and incorporated ice from the surface of the glaciers lower down as it ran over them. The Chinese seismic database registered two large "landslide" events on 22 October 2017: a M3.2 event at 06:20 (China standard time) about $16 \mathrm{~km}$ west of Sedongpu and a M4.0 event at 06:22 directly at Sedongpu. Chen et al. (2020) and Tong et al. (2018) confirm that at least the latter signal stems from the Gyala Peri ice-rock avalanche. Subsequent satellite images suggest that the avalanche must have changed the surface of Sedongpu Glacier drastically. It covered the glacier and much of the basin with debris and dust. A small, surge-like lobe with ponds on it appeared at the transition between the headwall and the tongue of Sedongpu Glacier (Fig. 13; GoogleEarth, Bing Maps). The eastern tributary glacier to Sedongpu Glacier also showed a surge-like lobe (Sentinel2, Planet, GoogleEarth). Driven by the geomorphological changes in the basin, a series of debris flows, some involving ice and likely nourished from the large amounts of unconsolidated debris left behind by the ice-rock avalanche, occurred after 22 October 2017 and into 2018 (Tong et al., 2018; Chen et al., 2020). The two 18 November 2017 M5.2 and M6.9 Linzhi, Milin, and Nyingchi earthquakes, with epicentres only a few kilometres from Sedongpu, may have contributed to the triggering of the debris flows (Hu et al., 2019; Zhao et al., 2019). Lastly, we report hundreds of small earthquakes recorded under the Gyala Peri massif in 2017 and 2018, most up to $M 2$, some up to $M 3$, which we have not analysed further in the present study (China Earthquake Data Center, 2021, http://data.earthquake.cn/index.html, last access: 7 April 2021). 

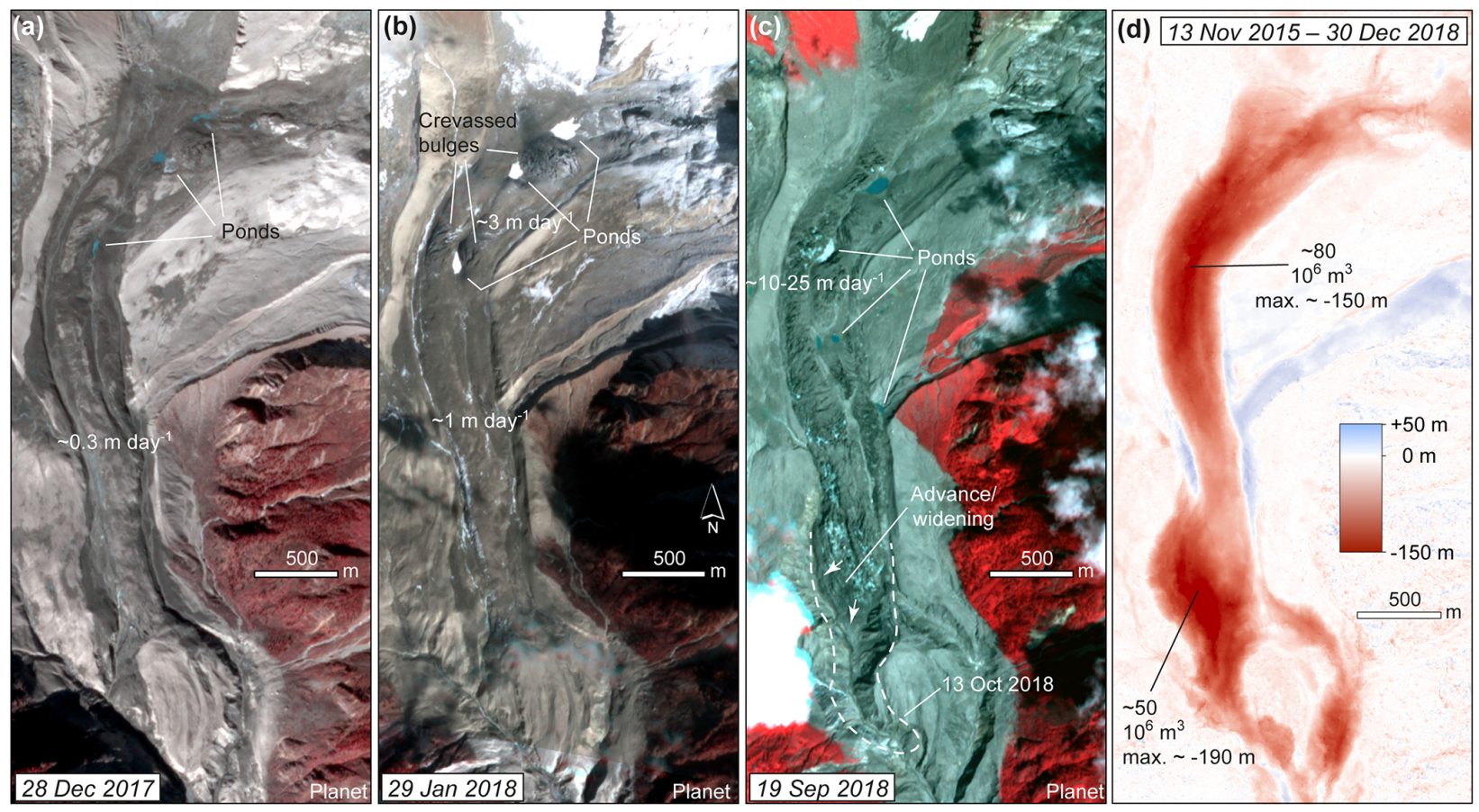

Figure 13. (a-c) Evolution of Sedongpu Glacier towards instability and detachment. Average surface velocities around the image dates are indicated. (Satellite images (C) Planet.) Velocities and glacier position after 19 September 2018 (25 m d $\left.{ }^{-1}\right)$ are derived from Sentinel-1 radar images. (d) Detail of elevation model differences between SPOT6 13 November 2015 and Pleiades 30 December 2018 tri-stereo data. Elevation losses amount up to $190 \mathrm{~m}$, but the colour scale is saturated at $-150 \mathrm{~m}$.

\subsubsection{Detachment in 2018}

Following the 2017 ice-rock avalanche the main Sedongpu Glacier underwent drastic changes (Fig. 13). Ponds developed on its surface and along the margins (Supplement Fig. S7). Surface velocities increased from a background velocity of $\sim 0.3 \mathrm{~m} \mathrm{~d}^{-1}$ (ca. $100 \mathrm{~m} \mathrm{a}^{-1}$ ) in 2017 to $1-3 \mathrm{~m} \mathrm{~d}^{-1}$ at the end of January $2018,10 \mathrm{~m} \mathrm{~d}^{-1}$ in mid-September 2018 , and $25 \mathrm{~m} \mathrm{~d}^{-1}$ in mid-October 2018 (velocities derived from offset tracking in repeat Planet, Sentinel-1, and Sentinel-2 data). The glacier surface showed several crevassed bulges (Fig. 13b) in January 2018, and progressively more crevasses appeared as the glacier tongue expanded (Fig. 13c; Supplement Fig. S7). The lower, flat glacier part separated from the steep headwall. Between 19 September 2018 (last optical image due to later cloud cover) and 13 October 2018 (Sentinel-1) the glacier advanced by almost $1 \mathrm{~km}$. On 17 or 18 October (Tong et al., 2018; Chen et al., 2020), or 22:48 (China standard time) on 16 October according to Wang et al. (2020), the entire tongue of Sedongpu Glacier detached over a length of about $3.5 \mathrm{~km}$ (glacier width between 250 and $550 \mathrm{~m}$ ) (Figs. 12 and 13). Wang et al. (2020) provide inversions of regional seismic signals caused by the event. Planet images of 27 October 2018 and Chinese media images confirm that large amounts of ice blocked the Yarlung Tsangpo river (Fig. 12d). Parts of the emptied glacier bed filled up with enough ice debris that another mass flow originated from there on 29 October 2018. The dam in the Yarlung Tsangpo river was estimated to be roughly $40-60 \times 10^{6} \mathrm{~m}^{3}$ in volume (Chen et al., 2020). Differencing our 2015 SPOT6 and 30 December 2018 Pleiades tristereo DEMs (Fig. 13d) shows two areas of distinct volume loss: around $80 \times 10^{6} \mathrm{~m}^{3}$ are missing from the main branch of the glacier and around $50 \times 10^{6} \mathrm{~m}^{3}$ from its terminus and frontal moraine. An ASTER satellite stereo DEM of 11 November 2017 suggests that the volume loss over the glacier tongue and frontal moraine cannot have occurred before November 2017. From our data we cannot tell how much of the total $130 \times 10^{6} \mathrm{~m}^{3}$ stems from the main first glacier detachment event of 17/18 October 2018 and how much from the 29 October 2018 event. However, satellite images indicate that the first event involved by far the largest volume. The detached glacier part had an overall slope of only 8$9^{\circ}$. According to Obu et al. (2019) it should have been several hundred metres below the regional permafrost limit, but cold or polythermal ice is certainly found in the west wall of Gyala Peri and could theoretically be advected into the basal parts of the glacier near its tongue.

Between 19 September and 26 October 2018 (Planet) a $\sim 9 \times 10^{6} \mathrm{~m}^{3}$ rock(-ice) avalanche (volume from 2015 SPOT6 and 2018 Pleiades tri-stereo DEM differencing) originated from the south-western flank of Gyala Peri and likely reached Sedongpu Glacier (Fig. 12). The avalanche covered a small glacier below its starting zone which started a surge- 
like advance in early 2018. Due to insufficient satellite data (cloud cover in optical data; low resolution and radar shadow in synthetic aperture radar, SAR, data), though, we cannot tell if this avalanche happened before, during, or after the 17/18 October 2018 glacier detachment and could thus have triggered the glacier detachment. Seismic records are also inconclusive regarding the rock avalanche and the glacier detachment, with two dozen $M 1-2$ earthquakes recorded under the Gyala Peri massif between mid September and end of October 2018.

From all the evidence collected above, it seems very likely that the 22 October 2017 Gyala Peri rock avalanche, which travelled over the Sedongpu Glacier, primed the glacier for its detachment a year later, perhaps with the additional influence of the 18 November 2017 earthquakes (Zhao et al., 2019) or one on 16 October 2018 (Wang et al., 2020), though the exact controlling mechanisms remain unclear. The effects that the ongoing mass-wasting activities from Gyala Peri had on Sedongpu Glacier could have been manyfold: additional loading on the glacier could have increased normal and shear stresses, and the 2017 rock avalanche and earthquakes could have mechanically weakened the glacier and its bed, potentially disrupting the subglacial drainage system. The large amounts of fine dust deposited on the glacier will likely have changed (enhanced?) its surface melt rates. Lastly, independent factors such as high temperatures and precipitation amounts (Tong et al., 2018; Liu et al., 2019) associated with large water input into the glacier could have complicated the changes caused by a rock-avalanche impact. The supraglacial and glacier-marginal ponds, unusual on temperate glaciers (see Haeberli et al., 2002; Kääb et al., 2004), suggest that the glacier was under high internal water pressure. The bulging ice and the strong downstream gradient in surface velocities suggest that a surge-like instability first developed in the upper section of the low-angle part of the glacier. Just how this instability propagated down-glacier, whether by exerting pressure on the lower glacier from above or by a propagation of exceptionally low basal friction values (Thogersen et al., 2019), remains unclear. High-resolution imagery and media photos of the glacier bed and detachment deposits, as well as the various debris flows that originated from the basin, suggest that the detached glacier rested on a soft bed with substantial amounts of fine material. The geology of the area is described as marble (Liu et al., 2019), which at least opens up the possibility of fine-grained sediments.

It remains to be seen to what extent the Sedongpu Glacier is able to rebuild given the strongly negative mass balances in the region (Kääb et al., 2015; Brun et al., 2017; Treichler et al., 2019; Shean et al., 2020).

\subsubsection{Zelunglung Glacier surge-like instabilities}

The region around Sedongpu does not seem to host any obvious surge-type glaciers. However, the events at Zelunglung Glacier $\left(29.62^{\circ} \mathrm{N}, 95.00^{\circ} \mathrm{E}\right.$; GLIMS G095018E29637N,
RGI60-13.01428), $20 \mathrm{~km}$ south of Sedongpu, are worth mentioning. In 1950, 1968, and 1984 extraordinary instabilities propelled the glacier forward and blocked the Yarlung Tsangpo river (Zhang, 1992). The 1984 event seems to have involved only a smaller section of the glacier. Corona reconnaissance satellite images of 1969 show a massive advance (by about $4.5 \mathrm{~km}$ compared to 2018) but no detached glacier. However, the glacier had obviously overridden its frontal moraine, reaching almost down to Yarlung Tsangpo. Deposits, visually similar to those of ice-rock avalanches in general, cover much of the main Yarlung Tsanpgo river bed at a length of about $2.5 \mathrm{~km}$ downstream measured from the confluence with the Zelunglung valley (Supplement Fig. S8). Glacier advance rates of up to $1 \mathrm{~km} \mathrm{~h}^{-1}$ are reported for the 1950 event (Zhang, 1992). Such rates are far above what is typical for surges, and the glacier might have, at least in 1950, undergone an event close to a sudden detachment in the sense of the present contribution.

\subsection{Flat Creek, 2013, 2015, and 2016, Alaska}

Flat Creek Glacier, a small glacier in the north-eastern corner of Alaska's St. Elias mountains (Fig. 14), produced two large glacier detachments in 2013 and 2015. This region in Alaska is home to many surging glaciers (e.g. Harrison et al., 2015; Sevestre and Benn, 2015; Kochtitzky et al., 2019), and a glacier in a valley adjacent to Flat Creek surged between 2012 and 2016. Located in the rain shadow of the St. Elias range, the area receives on average about $350 \mathrm{~mm}$ of precipitation annually (2008-2018). A mean annual air temperature of $-14{ }^{\circ} \mathrm{C}$ at the former terminus of Flat Creek Glacier, ground temperature measurements, and electrical resistivity tomography surveys strongly suggest that the headwall is underlain by continuous permafrost (Jacquemart et al., 2020).

On 5 August 2013, the lower $500 \mathrm{~m}$ of the glacier detached, releasing $6.8-11.2 \times 10^{6} \mathrm{~m}^{3}$ of ice and lithic material. On 31 July 2015, most of the remaining glacier ice (up to the drainage divide) detached, evacuating an additional 17.6$20.1 \times 10^{6} \mathrm{~m}^{3}$ (Jacquemart et al., 2020). Both events produced runouts of over $11 \mathrm{~km}$ (angle of reach 6-7 $7^{\circ}$ ), deposited vast amounts of lithic material, and buried several square kilometres of old growth forest $(400+$ years old). The large amount of fine-grained sediment found in the deposits suggests that the failures occurred within the glacier bed rather than at the ice-bed interface. The detachment slope was determined to be $\sim 20^{\circ}$.

A remarkable feature of Flat Creek glacier was a $\sim 70 \mathrm{~m}$ tall bulge upstream of a stagnant, crevasse-free tongue. A similar bulge on Trapridge Glacier, a polythermal surge-type glacier $80 \mathrm{~km}$ south-east of Flat Creek, was shown to have formed because a cold-ice tongue buttressed temperate ice upstream (Clarke and Blake, 1991). Based on the low annual air temperature and the presence of continuous permafrost, Jacquemart et al. (2020) concluded that the bulge on Flat Creek glacier was also the consequence of a polyther- 


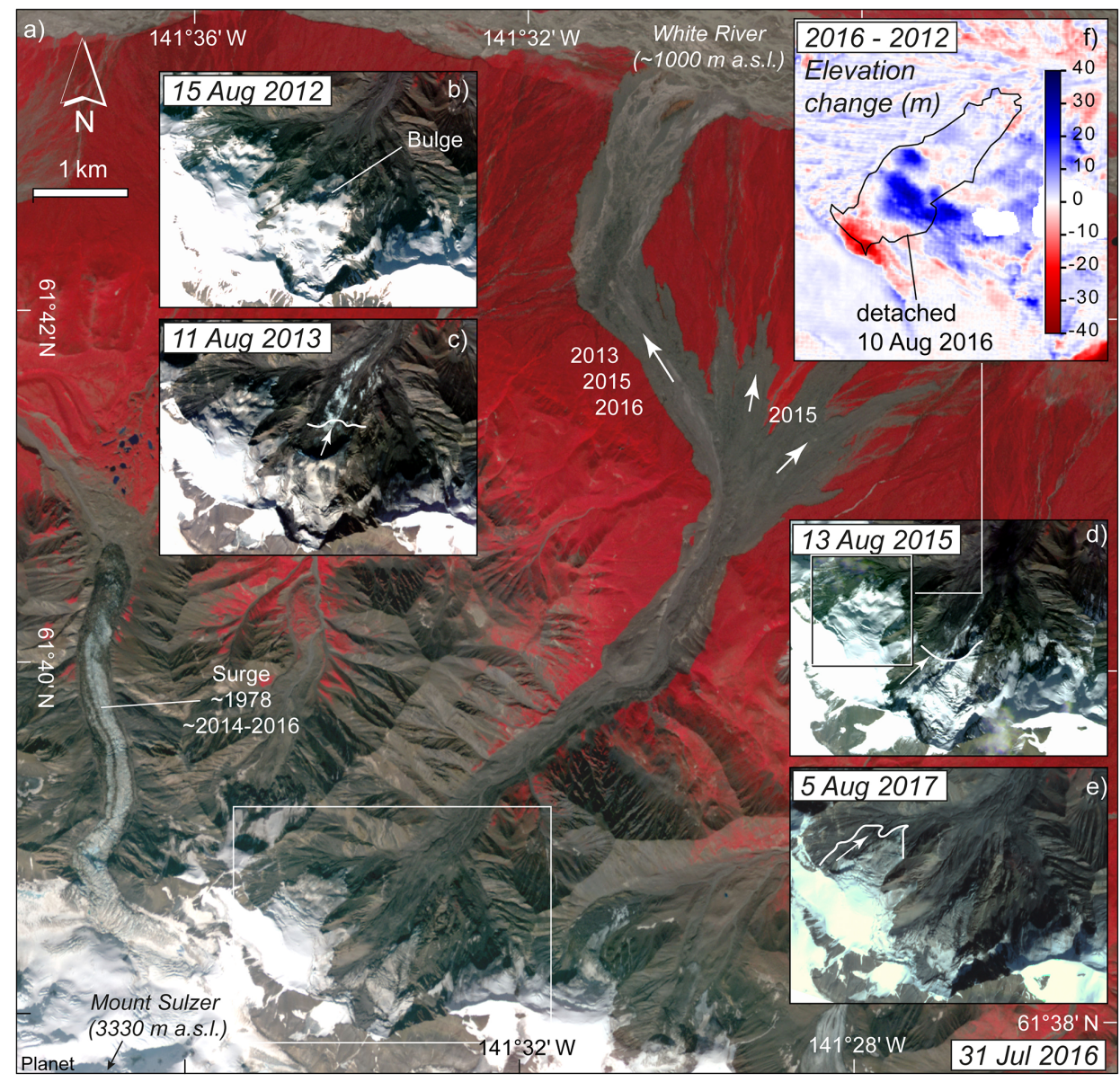

Figure 14. (a) Overview of the three detachments and ice-rock avalanches from Flat Creek Glacier, Alaska, since 2012. (b) In the 15 August 2012 inset, a bulge is visible on the lower part of the glacier. (c) In the 11 August 2013 inset, the glacier part that detached on 5 August 2013 is indicated with the front position before the event (white line). (d) In the 13 August 2015 inset, the detachment of 31 July 2015 and the front position before it are indicated. (e) In the 5 August 2017 inset, the area of the 10 August 2016 detachment is shown. All images (C Planet (Dove and RapidEye satellites). (For more images and front positions, see Jacquemart et al., 2020.) (f) DEM difference between 13 March 2016 (Arctic DEM) and summer 2012 (Alaska interferometric synthetic aperture radar, IfSAR) showing surge-like mass redistribution (see also Supplement).

mal regime. Measurements of the bulge position in satellite images suggest that the bulge advanced between 2011 and 2013, likely increasing driving stresses locally.

The 2013 and 2015 detachments both occurred at the peak of their respective melt seasons. Using a degree-day model, Jacquemart et al. (2020) found that the water availability during the exceptionally warm summer of 2013 was primarily melt driven and up to 4.8 standard deviations $(\sigma)$ above the long-term mean (1979-2015). No detachments were detected in 2014 when water availability was below average $(-0.5 \sigma)$. Water availability was again higher in $2015(+1 \sigma)$ when the second detachment occurred.

In 2016, a third glacier detachment released from a much steeper glacier $\left(\sim 30^{\circ}\right)$ in the same cirque (not described in Jacquemart et al., 2020, but mentioned in Jacquemart and Loso, 2019). We differenced a 13 March 2016 Arctic DEM and a structure-from-motion DEM from a 2019 aerial survey and estimate the volume of this detachment to be $4.7 \pm 0.2 \times 10^{6} \mathrm{~m}^{3}$. DEM differences over 2012-2016 show bulging of up to $30 \mathrm{~m}$ in the lower part of the glacier section that detached and surface lowering in its upper part (Fig. 14f; Supplement Fig. S9). The detachment causes have not yet been investigated, but the moving mass of ice was caught on video by rangers on a coincidental overflight. The speed of the observed mass flow was about 3 times slower than that of the 2013 and 2015 events. Nevertheless, the churning mass of ice blocks (termed a "slush-avalanche" by Jacquemart and Loso, 2019) provides a sense of what the much larger flows may have looked like.

\subsection{Aparejo, 1980, Chilean Andes}

On 1 March $1980,7 \times 10^{6} \mathrm{~m}^{3}$ ( $85 \%$ of its total volume) sheared off the debris-covered Aparejo Glacier in the Chilean 
Andes, mobilizing the detached mass $3.7 \mathrm{~km}$ down-valley with an estimated speed of $110 \mathrm{~km} \mathrm{~h}^{-1}$ (Ugalde et al., 2015, 2017; Ugalde, 2016) (Fig. 15). The slide deposit covered an area of $0.55 \mathrm{~km}^{2}$ with ice and rock debris piled up to $17 \mathrm{~m}$ thick. The volume of the deposit was estimated at $8.1 \times 10^{6} \mathrm{~m}^{3}$ (Marangunic, 1980). Five mountaineers witnessed the event and noted several supraglacial ponds and 2$3 \mathrm{~cm}$ of wet snow on the surface of the glacier (Marangunic, 1980). These observations suggest that the triggering mechanism of the glacier detachment likely involved an extreme reduction of the basal drag due to high water saturation of the glacier bed. Aparejo Glacier appears to sit on a glacier bed composed primarily of weak subglacial till, and the slope on the lower two thirds of the glacier averages $7^{\circ}$. Snowmelt infiltration and warm precipitation due to a sudden increase in the zero-degree isotherm elevation could have provided the main source of infiltrated water, leading to enhanced water pressure at the glacier bed. During a field inspection on 12 March 1980, Marangunic (1980) found that the nearby debris-covered glacier to the east, glacier number 51 according to the Chilean glacier inventory at the time (Fig. 15), also showed significant signs of surge-like instability, such as a heavily crevassed front and patches of freshly exposed ice along its entire length. The prominent terminal moraine of this glacier may have contained its detachment, though.

The Aparejo glacier is situated in a region of complex geology with a number of weak rock formations, including sandstones and fine-grained conglomerate in the immediate vicinity of the glacier (Ugalde, 2016). Ugalde (2016) sampled the grain size distribution of the remains of the lower ice-rock avalanche deposits and did not find them to contain more fines than a typical moraine but notes that spatial variability was high and that the 35 years since the detachment may have depleted the deposits of fine particles. In the former avalanche path, modern satellite images show streamlined debris stripes similar to those reported from several other detachments in this contribution. Remarkably, similar debris stripes are also visible in Hycon air photos from 1956. Interestingly, the geomorphology of the deposit area is similar between the 1956 air photos and the post-1980event high-resolution satellite images. One possible interpretation of this is that large mass flows had already originated from the Aparejo cirque at earlier times. A detailed field investigation would be required to determine whether the debris stripes consist of glacial flutes formed under a previous glacier extent or stem from a catastrophic detachment.

In 2015, the glacier had around $15 \%$ of its pre-detachment volume, covering much of the original area, and a surface slope of around $20^{\circ}$ (Ugalde, 2016). The current glacier terminus lies at around $3400 \mathrm{~m}$ a.s.l., slightly below the lower regional limit of discontinuous permafrost, estimated by Brenning (2005) to be at around $3500 \mathrm{~m}$ a.s.l. Consistent with regional glacier mass balance trends (Falaschi et al., 2018b; Braun et al., 2019; Dussaillant et al., 2019), decreasing ice thicknesses have been identified on the lower and middle sec-
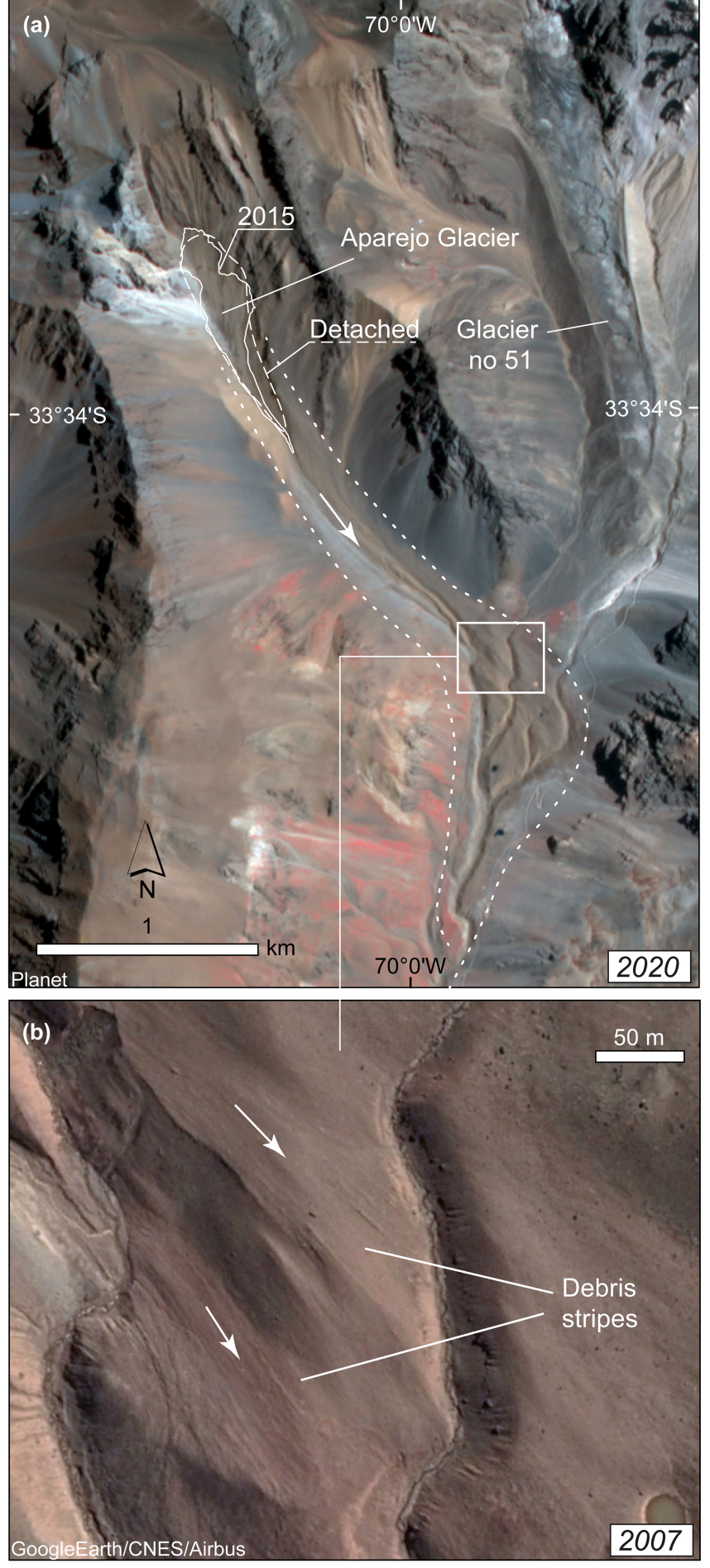

Figure 15. Aparejo Glacier, Chilean Andes. (a) Satellite image (C) Planet) of 27 January 2020 with the outlines of the detached glacier as a solid line, and the outlines of the 1980 detachment and runout roughly indicated as dashed lines (outlines based on Marangunic, 1980; Ugalde, 2016; Ugalde et al., 2017). (b) Detail of avalanche path (rectangle in a) with streamlined debris stripes. Satellite image: (c) Google Earth and CNES/Airbus, 29 February 2016. 
tions of the Aparejo glacier (Ugalde et al., 2017), pointing to the glacier shrinking under current climate conditions.

\subsection{Leñas, 2007, Argentinean Andes}

The $4 \times 10^{6} \mathrm{~m}^{3}$ detachment of Leñas Glacier between 5 and 14 March 2007 was discovered only recently since it happened in a very remote region and had no downstream impacts (Fig. 16). Meanwhile, the case is described in detail by Falaschi et al. (2019). The detached lower glacier section had a surface slope of around $15-16^{\circ}$. The glacier tongue at around $3450 \mathrm{~m}$ a.s.l. is suggested to lie within the zone of discontinuous permafrost in the region. The bed characteristics of the glacier are not known, but large amounts of fine sediments were found over the runout area of the event. A number of glacier surges are documented in the wider region but not for Leñas Glacier itself (Falaschi et al., 2018a, 2019). At the location of the later head scarp of the detachment, pronounced transverse crevasses are visible in air photos from 1970 and in a satellite image from a few weeks before the event (SPOT5). It is hard to determine, however, if these crevasses could have been signs of abnormal glacier behaviour or rather a pre-existing feature that then naturally formed the upper failure scarp. Transverse undulations of the glacier surface, as indicated in the 2000 SRTM DEM, and a slight increase in surface gradients at the location of the crevasse zone favour the latter scenario.

\subsection{Tinguiririca, 1994 and 2007, Chilean Andes}

\subsubsection{The 1994, 2007, and possible 1962 events}

A detachment from a glacier on the southern flank of the Tinguiririca Volcano (Fig. 17) happened between 27 June (Landsat 5 TM) and 6 July 1994 (Landsat 5 TM). For the event, we estimate a detached glacier area of $0.2 \mathrm{~km}^{2}$. Using glacier thickness estimates derived for the 2007 case (described below), we estimate a detachment volume of roughly $4-5 \times 10^{6} \mathrm{~m}^{3}$. The climatic conditions between 1994 and 2007 were obviously favourable enough (i.e. little negative or even balanced regional glacier mass balances; Masiokas et al., 2016; Dussaillant et al., 2019) for the glacier to recover to its pre-detachment geometry.

At the same location, a glacier area of $0.46 \mathrm{~km}^{2}$ detached between 7 January (Landsat ETM+ image without collapse) and 14 January 2007 (Landsat ETM+ with collapse), producing an ice and debris avalanche of $10-14 \times 10^{6} \mathrm{~m}^{3}$ volume (Schneider et al., 2011; Iribarren Anacona et al., 2015; Figs. 17, 18). We estimate that the detached glacier had a surface slope of around $20^{\circ}$. Before the 2007 detachment, the glacier's lowest elevation was at about $3500 \mathrm{~m}$ a.s.l., roughly at the lower regional limit of discontinuous permafrost (Brenning, 2005). The volcanic nature of Tinguiririca should be associated with weak rocks and sediments. There are fumarolic fields and hot springs within a few kilo- metres of the detached glacier (Pavez et al., 2016), and an inactive volcanic crater lies just a few hundred metres to the west of the detached glacier. In very high-resolution satellite images of 2007 and later (GoogleEarth, BingMaps), clear signs of hydrologic activity are visible in the upper part of the detachment area: freshly eroded channels, wet looking areas, and deposits from small debris flows - all perhaps signs of geothermally enhanced melt of snow and ice (Fig. 18). In the path of the ice-rock avalanche we find streamlined debris stripes similar to those found in the Kolka, Rasht 2019, and Aparejo avalanche paths (Fig. 18). As of late 2019 , the glacier has not recovered from its 2007 detachment, and there are only a few small snow (or ice?) fields visible at its location. Elevation differences between 2000 (SRTM DEM, before detachment), 2007-2010 (ALOS PRISM, after detachment), and 2010-2015 (TanDEM-X; both the ALOS PRISM and TanDEM-X DEMs are multi-year composites, and therefore their date range is given) suggest that the detached glacier had average and maximum thicknesses of 21-28 and 50 m, respectively. Combined with the detached glacier area of about $0.5 \mathrm{~km}^{2}$, we estimate a detachment volume of roughly $10.5-14 \times 10^{6} \mathrm{~m}^{3}$, which is in good agreement with Iribarren Anacona et al. (2015). The Tinguiririca case illustrates how glacier removal by the 1994 detachment was largely reversible as the glacier built up again to failure conditions under the climate at that time, whereas the 2007 glacier removal seems irreversible under the current climate and associated negative glacier mass balances in the region (Falaschi et al., 2018b; Braun et al., 2019; Dussaillant et al., 2019).

In air photos from 1962 and Corona-series reconnaissance-satellite images from 1967, we notice debris stripes in the valley similar to the ones visible after the 1994 and 2007 events and other cases described in this contribution. Over the glacier, the 1962 air photos clearly show that a glacier detachment similar to the 1994 event must have occurred not long (weeks, months, or a few years?) before the image was taken. Stripes of debris or ice remains after the avalanche are still well preserved in the 1962 images over the glacier (Fig. 18d). (The associated terrain sections are under snow cover in the 1967 Corona images.)

\subsubsection{A potential large pre-1970s detachment of the neighbouring glacier}

In the neighbouring valley to the east (Fig. 19) we note geomorphological traces that could be investigated further with regard to their origin from volcanic mass movements, earlier glacier stages, glacier surging, or more glacierdetachment-like events. In the lower part of this potential event path we find debris stripes similar to the ones from the Tinguiririca, Aparejo, and other avalanches of this study, largely unchanged since the first available Corona-series reconnaissance-satellite images in 1967 (Fig. 19c) and air 

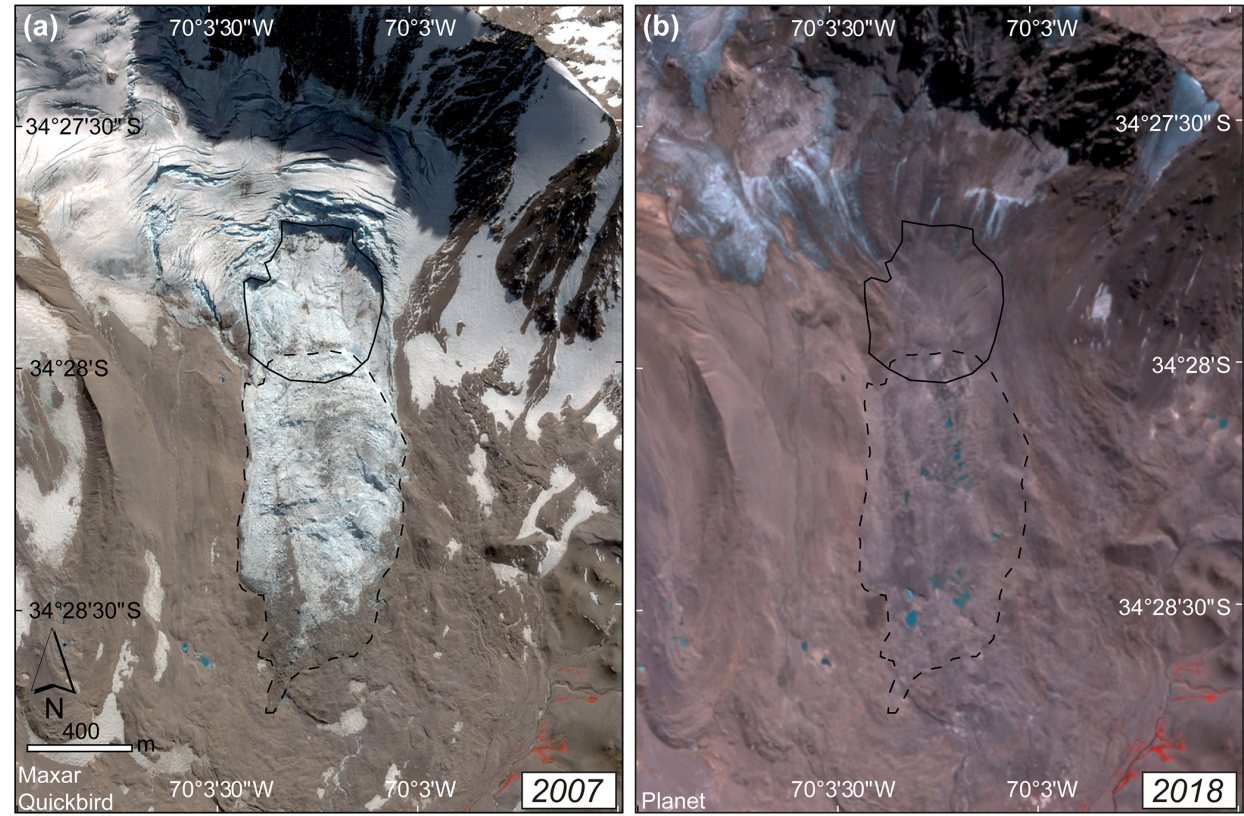

Figure 16. (a) QuickBird satellite image of 19 April 2007 over Leñas Glacier, Argentinian Andes, a few days after detachment (ㄷ Maxar). (b) Planet image of 28 March 2018. Bold lines in both panels indicate the detached glacier part and dashed lines the outlines of the avalanche deposits. (ㅇ Planet).

photos from 1962. Only detailed field work would be able to rule out the possibility that these debris stripes consist of glacial flutes or small lateral moraines formed during a previous glacier extent or were produced by a glacier surge. It should also be investigated whether such debris stripes can remain largely intact after having been overrun by an icerock avalanche or if it is an indicator of the most recent event (see also Aparejo, where similar questions turned up).

In the upper part of this valley or in the potential event source area, we observe two noticeable changes over time. First, the tongue of this unnamed glacier (RGI60-17.01112, GLIMS ID: G289692E34781S) was much smaller in 1962 air photos than it is in 2020. Its advance of roughly $1.5 \mathrm{~km}$ since 1962, most of which occurred between 1975 and 1986 (Landsat), is in stark contrast to the pronounced shrinkage of the other glaciers in the area (Figs. 17, 19). Indeed, differencing a DEM, which we produced from 1962 stereo air photos, from the SRTM or TanDEM-X DEMs confirms elevation gains on the glacier tongue of up to $120 \mathrm{~m}$ between 1962 and 2000 (SRTM) or up to $150 \mathrm{~m}$ between 1962 and 2010-2015 (TanDEM-X; Fig. 19c). This development could point to the recovery of the glacier tongue after a removal some time before 1962 . The volume gain of the glacier tongue between 1962 and 2000 is around $70 \times 10^{6}$ or $100 \times 10^{6} \mathrm{~m}^{3}$ between 1962 and 2015.

Second, we detected an elevation decrease in the glacier forefield of around 10-15 m between 1962 and 2000 which could point to the deflation of debris-covered ground ice deposited by a possible surge or glacier detachment (Fig. 19c).
Third, a comparison of the 1962 air photos to contemporary images revealed a heavily bulged glacier surface between 3900 and $4650 \mathrm{~m}$ a.s.l. (Fig. 19a, b). Visually, this bulging is similar to the bulge found on Flat Creek Glacier prior to its 2013 detachment (Sect. 3.7). The slope of the glacier tongue is around $8-10^{\circ}$ and around $35^{\circ}$ for the steep upper part. The bulging upper part of the glacier is far above the regional permafrost limit so that polythermal ice conditions might well be found in parts of it.

We also examined a 1955 Hycon aerial photo (no stereo data to produce a DEM available to us), but visual interpretations from it remain inconclusive. Under illumination conditions that are very different from those of the $1962 \mathrm{im}$ ages, the headwall glacier cover and the tongue seem larger in 1955 than in 1962, resembling rather its shape and extent of the 1980s. Below the position of the current (2020) glacier terminus, there seem to be dead-ice remains visible in the 1955 images. These are also visible in the $1962 \mathrm{im}$ ages though they are shrunken. It remains thus to be clarified at this point to what extent the features observed can be explained by a surge or series of surges of the glacier before 1955 or between 1955 and 1962 or by a detachment-like event. 


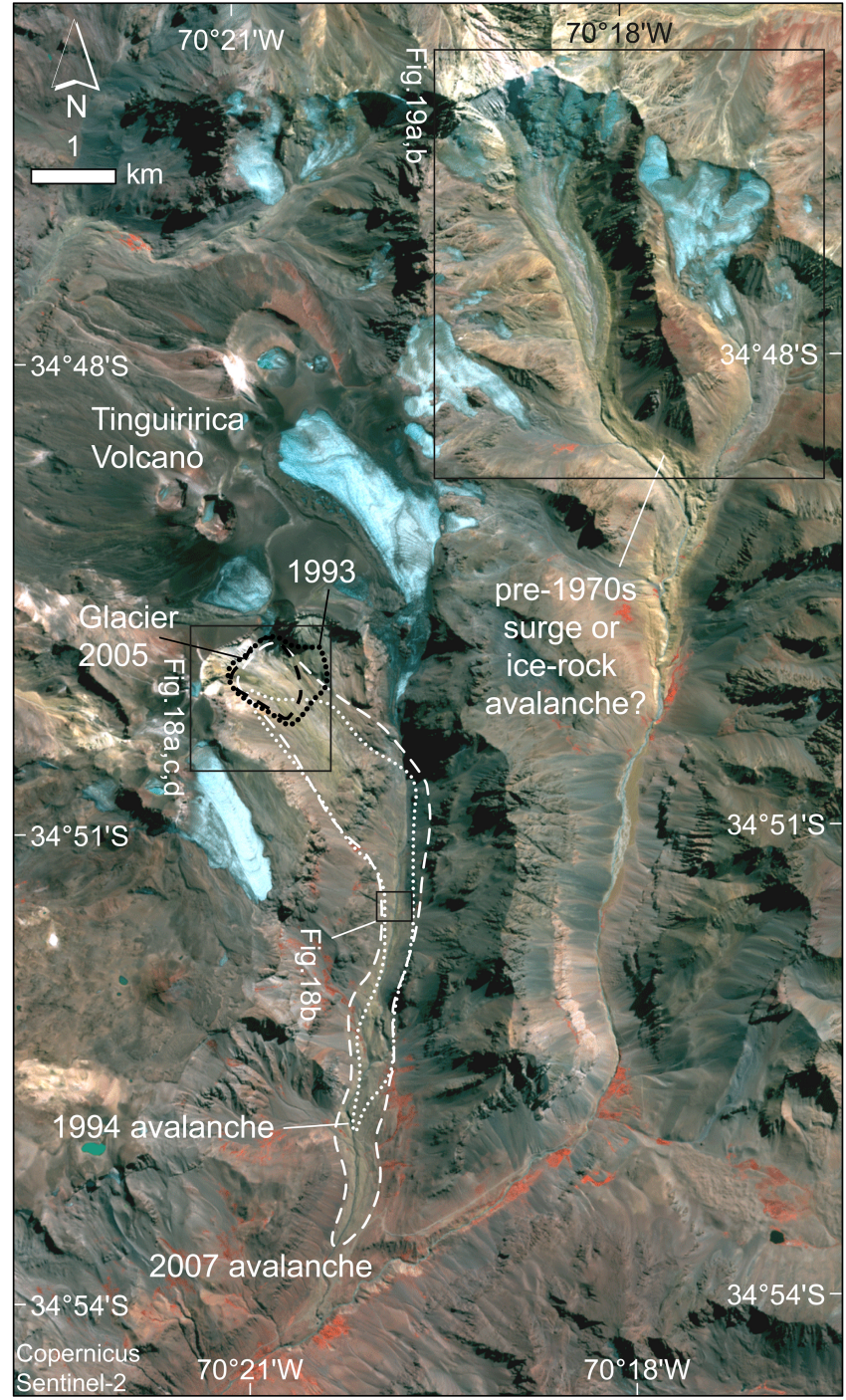

Figure 17. Tinguiririca Volcano, Chilean Andes. Outlines of the 1994 and 2007 ice-rock avalanches and the 1993 and 2005 area of the detached glacier as dotted and dashed lines, respectively. These outlines have been digitized for this study but were found to agree well with the ones in Iribarren Anacona et al. (2015). Satellite image: Sentinel-2, 14 March 2020 (credit: Copernicus Sentinel data).

\section{Discussion}

\subsection{Simplified force and energy balance}

\subsubsection{Idealized slab model}

The conditions under which a detachment might occur can be qualitatively understood from a simple force balance analysis. To simplify the problem, we represent the potential detachment as a rectangular slab (Fig. 20a). The force balance between gravitational (left part of Eq. 1) and resistance forces (right part of Eq. 1) gives the following relationship:

$W L h \rho g \sin (\alpha)=W L \tau_{\mathrm{b}}+2 h L \tau_{d}$,

and by solving for $\tau_{d}$,

$\tau_{d}=\frac{W}{2 h}\left(\rho g h \sin (\alpha)-\tau_{\mathrm{b}}\right)$,

where $\tau_{d}$ is the lateral shear stress $(\mathrm{Pa}), W$ is the slab width (m), $L$ is the slab length ( $L$ is cancelling out in Eq. 1), $h$ is the slab thickness (m), $\rho$ is the density of ice $\left(\mathrm{kg} \mathrm{m}^{-3}\right), g$ is the gravitational acceleration $\left(\mathrm{m} \mathrm{s}^{-2}\right), \alpha$ is the slab slope, and $\tau_{\mathrm{b}}$ is the basal shear stress $(\mathrm{Pa})$. Assuming that the glacier driving stress is originally in balance with the basal shear stress under normal conditions $\left(\tau_{\mathrm{b}}=\tau_{0}\right)$, we have the following:

$\tau_{0}=\rho g h \sin (\alpha)$,

which gives the following equation by combining Eqs. (2) and (3) in a way that a ratio $\frac{\tau_{\mathrm{b}}}{\tau_{0}}$ appears, which allows us to compare potential failure conditions to normal conditions:

$\tau_{d}=\frac{W \rho g \sin (\alpha)}{2}\left(1-\frac{\tau_{\mathrm{b}}}{\tau_{0}}\right)$.

A collapse can only happen if $\tau_{d}$ exceeds the mechanical resistance of the slab margins (critical shear strength $\tau_{\mathrm{c}}$ ). Using the work of Gilbert at al. (2018) in which the evolution of the force balance toward the collapse of Aru glaciers has been quantified, we estimate $\tau_{\mathrm{c}} \cong 0.28 \mathrm{MPa}$ for the Aru glaciers and apply this value to the simplified glacier slab. This allows us, using Eq. (4), to define a stability diagram as a function of detachment width and slope and the ratio $\frac{\tau_{\mathrm{b}}}{\tau_{0}}$ (Fig. 20b).

This stability criterion seems to be respected by most of the detachments of our study (Fig. 20b), showing that the rough slab approximation may be a way to initially and qualitatively analyse which glaciers might be susceptible to detaching. In particular, the analysis shows which combinations of slope and width are unlikely to produce detachment when $\tau_{d}$ remains below $\tau_{\mathrm{c}}$ even for $\tau_{\mathrm{b}}=0$ (i.e. complete loss of basal friction; green area in Fig. 20b). Under the provisional assumption that $\tau_{\mathrm{c}}$ is similar for all the glaciers investigated, this analysis also shows that the detachments presented here happened for an average loss of friction between around $50 \%$ and $100 \%$ (i.e. $0<\tau_{\mathrm{b}} / \tau_{0}<0.5$ ). In reality, it is reasonable to assume that the basal friction rarely goes all the way to zero. Additionally, the critical lateral shear stress will vary between glaciers, depending, for instance, on whether the critical lateral resistance is provided by ice or by morainic margins and their properties and on topographic forms of resistance like glacier curves or bedrock bumps. For the Amney Machen detachment, which did not follow our provisional criteria (it failed at a critical shear stress of $0.2 \mathrm{MPa}$, which is smaller than the 0.28 MPa estimated for Aru), the detachment flanks consisted of sediments and might thus be weaker than the ice margins along which the Aru glaciers detached. For 

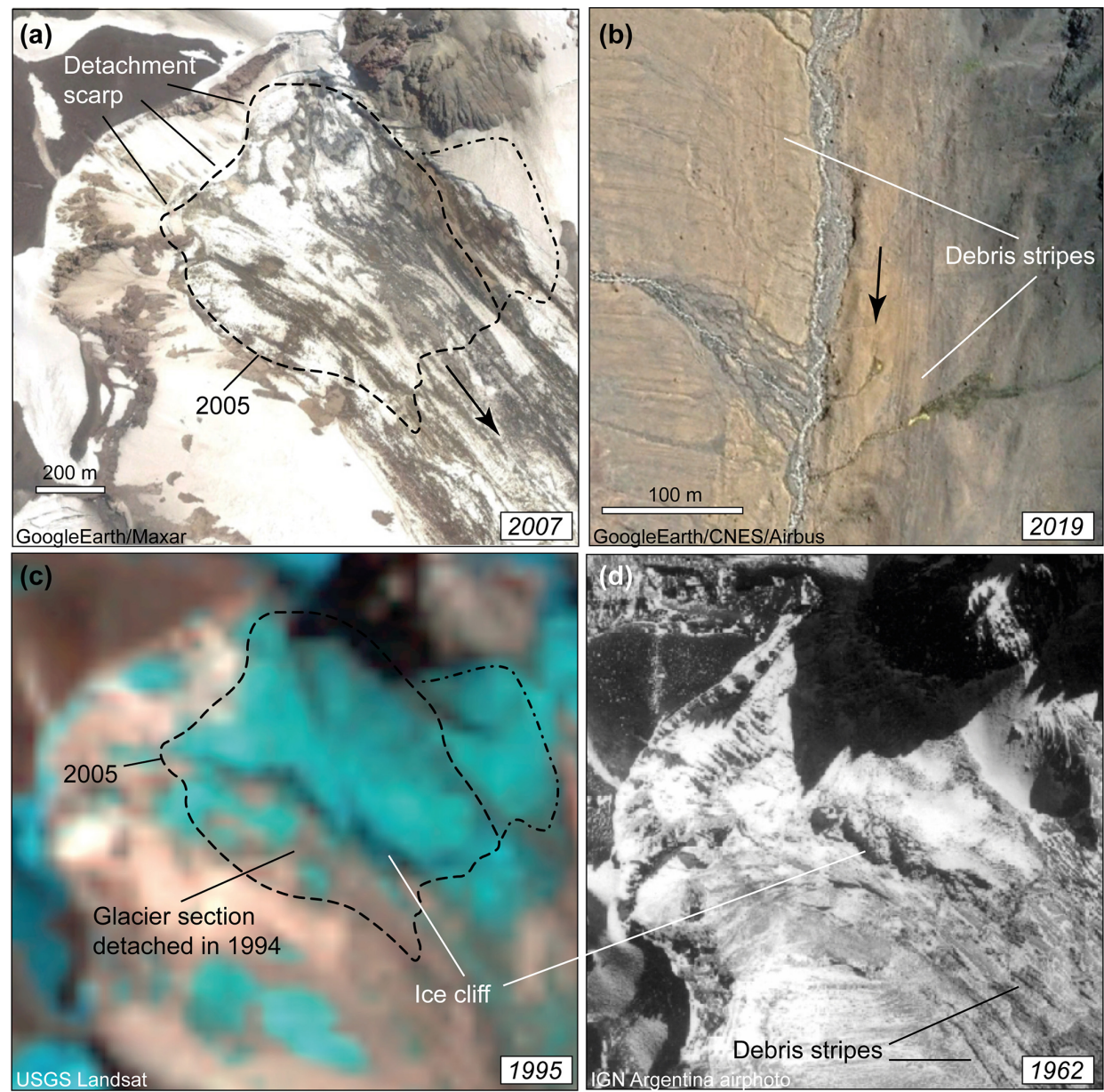

Figure 18. (a) Glacier detachment area at Tinguiririca Volcano on 24 January 2007 (satellite image: () Google Earth and Maxar). See Fig. 17 for location. Glacier outlines from 26 February 2005 Landsat data (latest snow-free image before 2007 detachment) indicated by dashed lines. From the $30 \mathrm{~m}$ resolution Landsat data it is unclear whether the dash-dotted ice section was connected to the main glacier. (b) Debris stripes left by the 2007 ice-rock avalanche (30 January 2019; ( ) Google Earth and CNES/Airbus). (c) A Landsat image of 19 March 1995 (first snow-free image after 1994 detachment; credit: USGS) shows that the southern part of the glacier detached in the 1994 event. Glacier outlines of 2005 dashed as in (a). (d) The glacier in an aerial image of 8 April 1962 (@ National Geographical Institute of Argentina). Clearly, a glacier section similar to the 1994 event has detached not long before the image date, leaving also a similar ice cliff. Streamlined debris stripes from the resulting avalanche are still well visible.

some glaciers the effective width of the detachment is difficult to estimate as it varies along the glacier length, and we cannot be sure at which width the failure started to develop. For Tinguiririca, the effective detachment width is particularly uncertain as the glacier rested on a bed ramp rather than between valley or moraine flanks. It remains to be investigated how the deviation of the cross sections of the detached glaciers from the idealized slab influences our stability analysis.

\subsubsection{Energy from precursory acceleration}

As will be discussed in the following sections in more detail, several of the detachments presented here showed precursory accelerations, some clearly surge-like. In the present section we discuss to what extent the meltwater production associated with this precursory motion could feed back on the reduction of basal shear stress. We take the case of the Aru-1 event (based on data in Gilbert et al., 2018) as an example. The first major dissipative losses of this event were during the pre-detachment accelerated sliding, which attained about $0.5 \mathrm{~m} \mathrm{~d}^{-1}$. Whereas some energy drove crevasse development and brittle-ductile changes in ice crystals, we suppose that most of this phase of energy dissipation occurred at the bed by the grinding of rocks and ice and melting of ice. The typical glacier thickness was $100 \mathrm{~m}$, so $1 \mathrm{~m}^{2}$ of bed area by $100 \mathrm{~m}$ column of ice at a density of $900 \mathrm{~kg} \mathrm{~m}^{-3}$ would have a mass of about $90000 \mathrm{~kg}$. Each day it slid downslope by about $0.5 \mathrm{~m}$, including an elevation drop of about $0.1 \mathrm{~m}$. The daily loss of potential energy of each such column of ice was thus 

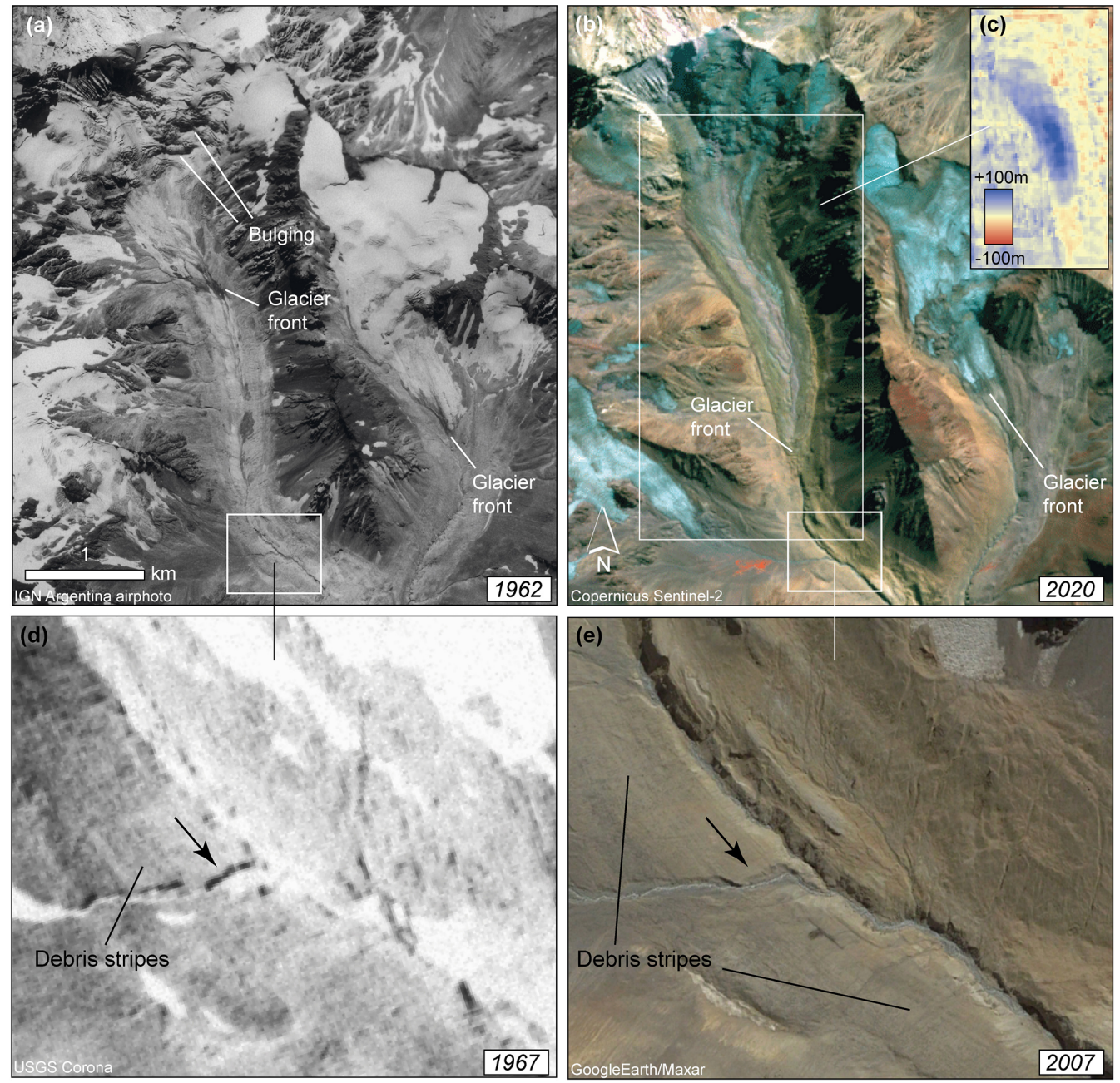

Figure 19. Glacier valley with potential former surge or glacier detachment east of Tinguiririca Volcano. See Fig. 17 for location. (a) Orthoprojected air photo of 8 April 1962 (@ National Geographical Institute of Argentina). (b) Sentinel-2 image of 14 March 2020 showing an advance of $1.5 \mathrm{~km}$ relative to 1962 in contrast to other, retreating glaciers in the area (credit: Copernicus Sentinel data). (c) Elevation differences between DEMs from 1962 stereo air photos and the 2000 SRTM show gains over the glacier tongue of up to $120 \mathrm{~m}$ and losses of around 10-15 $\mathrm{m}$ in the forefield. (d) Corona satellite image of 23 February 1967 with debris stripes (credit: USGS). (e) Satellite image of 19 March 2007 (@ Google Earth and Maxar). Panels (a) and (b) and (d) and (e) show the same terrain section each. Locations of (c), (d), and (e) indicated as white rectangles in (a) and (b).

about $88300 \mathrm{~J}$ (about $1 \mathrm{~W} \mathrm{~m}^{-2}$ ). If the ice was at the melting point, which it was across much of the bed within the frozen perimeter (Gilbert et al., 2018), this energy could melt up to around $0.26 \mathrm{~kg}$ of ice per square metre of thawed bed per day. If this continued for $200 \mathrm{~d}$ at such rapid sliding, about $53 \mathrm{~kg}$ of liquid water would be generated per square metre of thawed bed area, amounting to a roughly $5 \mathrm{~cm}$ layer of water (some energy may also have been expended in crushing rocks and ice). This water could be expelled, or it could be contained within the frozen confines of the polythermal glacier. If confined, this water could be ingested into basal till, perhaps dilating the volume of till and spreading it over a larger fraction of the bed, thus reducing the total frictional resistance in the thawed parts of the glacier; the water itself could spread over a larger fraction of the bed, or it could pool against the frozen toe and margins of the glacier. Additional water - maybe a lot more - likely was provided to the subglacial bed environment from rainfall and snowmelt sources. The role of the above $5 \mathrm{~cm}$ average thickness of frictional meltwater could become important if (i) it is a substantial proportion of the thickness of the basal till, (ii) if it is a significant proportion of the meteorological meltwater that reaches the bed, and/or (iii) if it can spread laterally over a large part of the thawed bed.

Not all detachments presented here were preceded by longer phases of surge-like acceleration, and surge-like acceleration typically does not lead to glacier detachment. Still, the above estimates exhibit a feedback process that could 
(a)

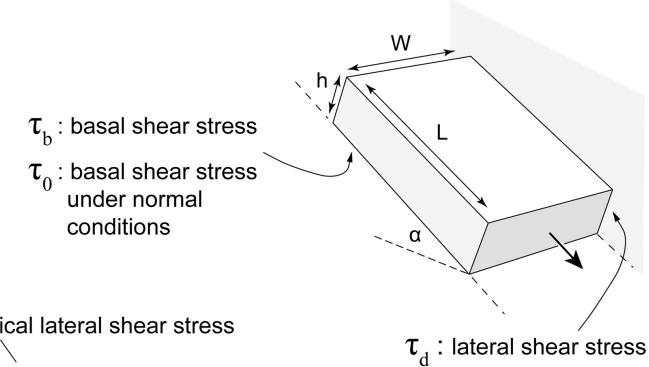

(b) $\tau_{\mathrm{c}}:$ critical lateral shear stress $\tau_{\mathrm{d}}$ : lateral shear stress

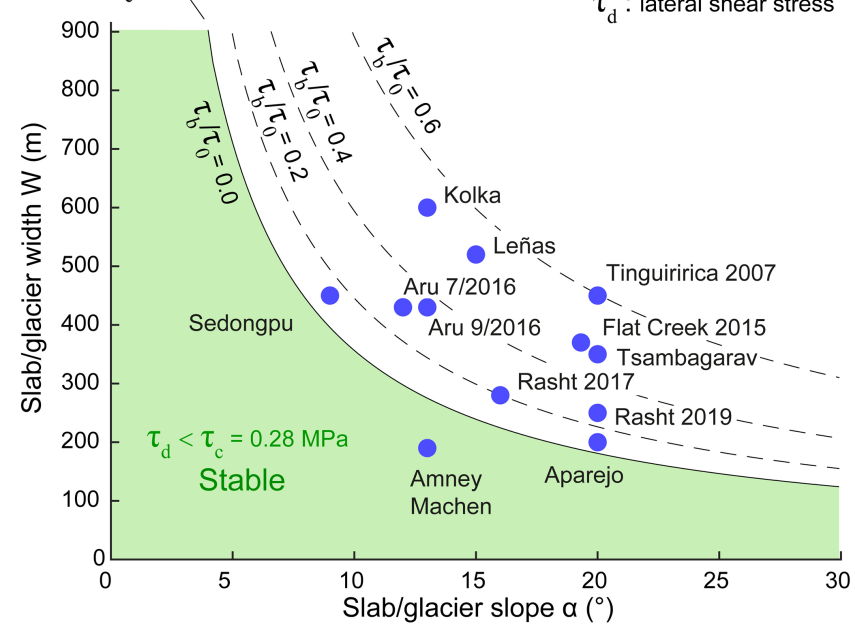

Figure 20. (a) Slab geometry used for the force balance analysis. (b) Stability diagram showing under which condition the slab would remain stable in the case of a total loss of basal friction $\left(\tau_{\mathrm{b}}=0\right.$; green area) and for different ratios of friction $\tau_{\mathrm{b}} / \tau_{0}$ (i.e. partial loss of basal friction; dashed lines). Blue dots show averaged slope and width of all detachments reported in this study. The critical lateral shear stress $\tau_{\mathrm{c}}$ has been estimated from the Aru glacier detachments using the force balance constructed in Gilbert et al. (2018).

through precursory acceleration facilitate a substantial reduction of basal shear stress and ultimately failure of soft beds.

\subsection{Similarities and differences}

The most apparent similarities among the detachments compiled in this contribution (Table 1) are their geographic proximity to surge-type glaciers - in some cases the detached glaciers themselves exhibited surging or surge-like behaviour - as well as the existence of weak bedrock and/or fine sediments around and likely at the base of the glaciers (Fig. 21). Both commonalities suggest that the sudden detachments of low-angle glaciers discussed here could be seen as rare and extreme endmembers of the range of surge-type and surgelike glacier instabilities (Quincey et al., 2015; Herreid and Truffer, 2016). The detachments could be a specific kind of glacier surge in which the force balance cannot be achieved by a global control, typically by longitudinal and lateral stresses when basal friction is suddenly reduced. In the case of a low bed roughness and an absence of sufficient topographic support, the reduced amount of stress accommodated by basal resistance can only be transferred to the margins (Fig. 20a) and leads to an expanding instability (Thogersen et al., 2019). This ultimately leads to a runaway acceleration and detachment. The loss of friction involved in such behaviour, more than $50 \%$ according to our idealized slab analysis, may only be reached by sustained low effective pressure. Such conditions are more plausible on soft-bed glaciers in contrast to hard-bed glaciers where increasing sliding velocity would lead to cavity opening and increasing drainage efficiency, making the preservation of high water pressure at the glacier bed unlikely.

In this context, we note that the surface slopes of the detached glaciers were between 9 and $21^{\circ}$ (average $15.9^{\circ}$, standard deviation $3.6^{\circ}$ ), which is at the upper end for slopes of surge-type glaciers yet surprisingly low for glaciers causing ice avalanches. The slope range of around $10-20^{\circ}$ may be a necessary condition for glacier detachments as a slope lower than $9^{\circ}$ is unlikely to drive a stress concentration that exceeds the critical shear stress even in the case of total loss of basal shear stress (Fig. 20b) (Sect. 4.1). At the same time, glaciers within the $10-20^{\circ}$ slope range still have considerable thickness and thus volume, while higher slopes sustain thinner glaciers and much smaller volumes involved in a potential failure (Fig. 1c). Our limited database of detachment events suggests a transition between larger and smaller detachment volumes at roughly around $14^{\circ}$ (Fig. 1c).

From a more mechanical point of view, low-angle glacier detachments can also be seen as part of the continuum between surges and ice break-offs from steep glaciers. Not least owing to their slope, glaciers have a range of possibilities to adapt to changes in their stress regimes (see Fig. 22). Flat glaciers can respond by adjusting their geometry, for instance, through advance and surging. On very steep terrain, glaciers may not be able to adjust their geometry smoothly, and ice breaks off. In contrast to the factors involved in typical ice break-offs from steep glaciers (see Sect. 1), glacier detachments appear to have in common basal failure on soft beds. Therefore, low-angle glacier detachments combine the elements of both instability processes: the inability to rapidly adjust geometry in response to stress changes, similar to steep glaciers, and a surge-like process that propagates an initial instability through large parts of the glacier (Thogersen et al., 2019), allowing entire glacier tongues to be mobilized. The latter framework for low-angle glacier detachments and the above one of surge endmembers are not mutually exclusive but rather linked by the role of glacier slope, fine basal tills, and the surge-like propagation of instabilities.

The role of basal water pressure in the detachments is difficult to examine in detail, but most detachments should have involved a severe reduction in friction (Sect. 4.1) likely due to high basal water pressure. Ways to rapidly increase basal water pressure include the following: an increase in water input (e.g. large high-altitude rain events, Kääb et al., 2018, or increased surface snowmelt and ice melt, Jacquemart et al., 2020) into a subglacial drainage system not ca- 


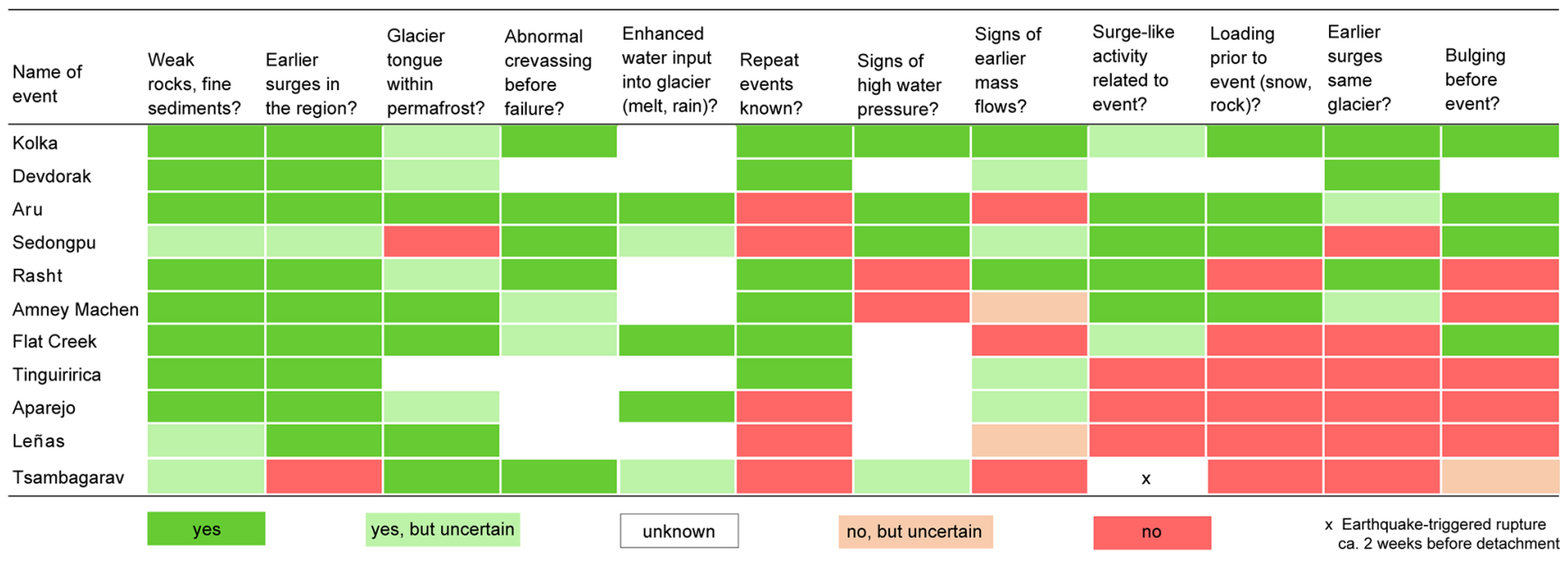

Figure 21. Possible indicators for and factors involved in low-angle glacier detachments. The columns and rows are roughly sorted according to increasing number of "no" entries towards the lower right.

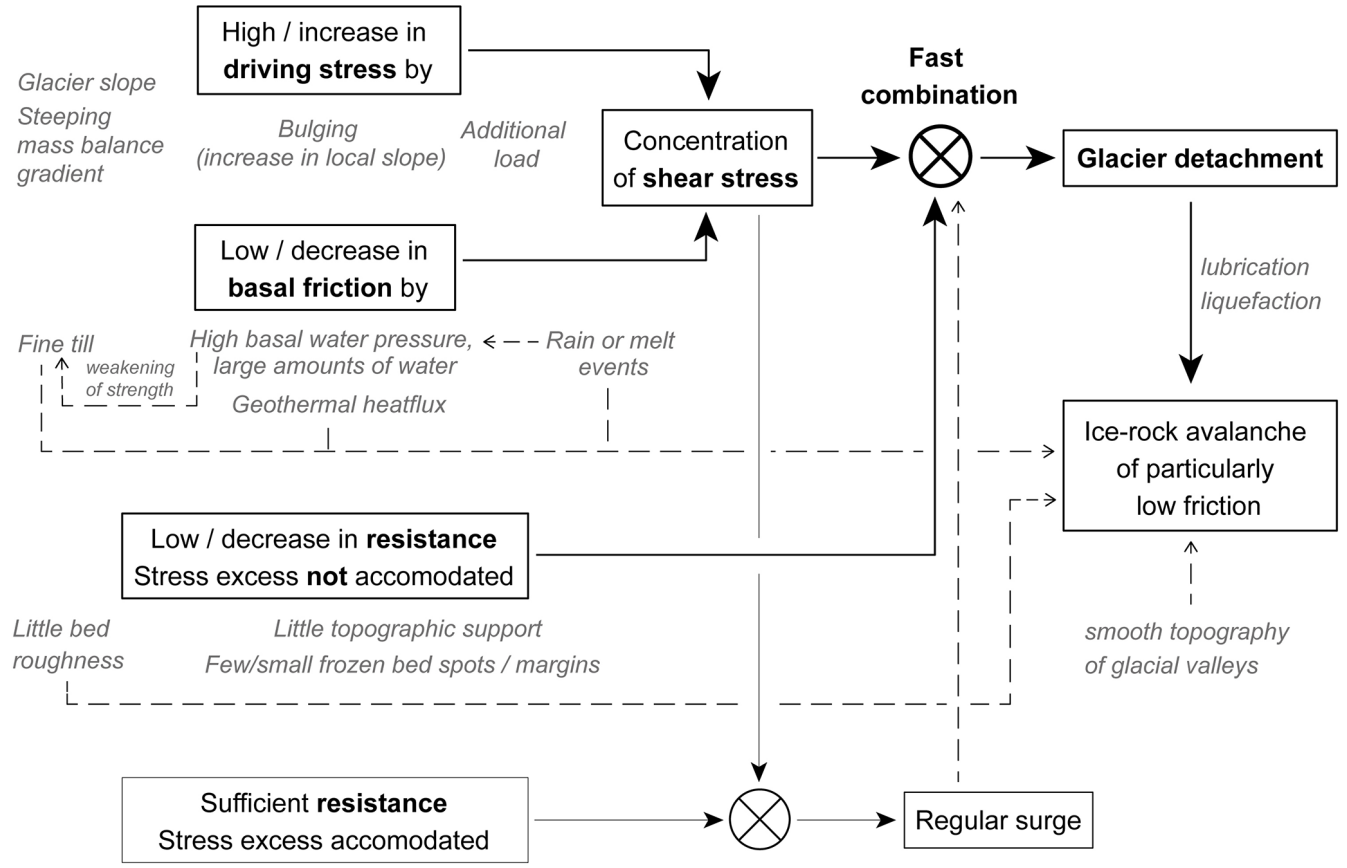

Large-scale topographic support (pinning points, bed topography, ...)

$\begin{array}{cc}\text { Long-term changes } & \text { Short-term changes } \\ \text { Disposition } & \text { Trigger }\end{array}$

Figure 22. Schematic on which conditions and changes to a low-angle mountain glacier can in combination lead to the spatio-temporal interference of particularly high and concentrated shear stresses and low resistance eventually exceeding stability thresholds and causing detachment. The failure conditions can change at a range of timescales so that detachment is the result of a highly transient and rare interplay of factors. It is key that the low basal friction and high driving stresses, the resulting concentration of high shear stresses, and the lack of sufficient resistance develop rapidly or are combined rapidly, preventing the glacier from adjusting to changing forces in a steady way. Several of the factors potentially involved in the detachment are subsequently also able to strongly reduce basal friction of the resulting ice-rock avalanche and lead thus to particularly low angles of reach. Boxes in the figure indicate main physical conditions, and grey italic text indicates different actual processes that can fulfil these conditions, sorted from long-term (left) to short-term (right) variability. 
pable of adjusting fast enough; inefficiencies or blockages of this drainage system; or increased permeability of the glacier through enhanced crevassing (e.g. Tsambagarav) (Dunse et al., 2015). Sudden weakening of the strength of subglacial till under high pore-water pressure and over large parts of the glacier bed was shown to be a key process leading to the Aru detachments (Gilbert et al., 2018). Ongoing surge-like activity may enhance sensitivity to water input (Flowers et al., 2016).

In Fig. 22 we attempt to summarize the main drivers of the glacier detachments described here. We define a detachment's disposition as the sum of long-term factors that might promote glacier detachments and refer to triggers to describe short-term factors that might suddenly tip the scale toward a catastrophic failure. Fundamentally, it seems that different combinations of dispositions and triggers are able to produce instability. Aside from the similarities mentioned above, the observed detachments all present some unique conditions, many of which remain shrouded in uncertainty. The observed failure conditions (Fig. 20) include ruptures during surge-like glacier instabilities (Kolka 1902, Aru, Amney Machen, Sedongpu; unclear: Devdorak), earthquaketriggered rupture (Tsambagarav), or increase in driving stress due to thickening caused by snow accumulation (Aru) or ice-rock avalanches (Kolka 2002, Amney Machen; uncertain: Sedongpu). Geothermal activity could have played a role at Tinguiririca and Kolka but is unlikely for the other events. The thermal setting of the detached glaciers can play a role if permafrost around the glaciers potentially causes frozen margins or the glaciers exhibit a polythermal structure (Aru, Flat Creek, Tsambagarav; uncertain: Tinguiririca, Leñas). However, other detachments happened under conditions very likely free of cold ice. Some of the detached glaciers seem to have been composed of a mixture of debris and ice (Amney Machen, Flat Creek; likely at least for Devdorak, Kolka, Sedongpu). Such mixtures can be profoundly weaker than clean glacier ice, particularly at temperatures close to the melting point (Moore, 2014), but it is unclear at this point whether and how these mixtures and their weakness may have contributed to the detachments. In contrast, the ice of the Aru glaciers and the glacier at Tsambagarav clearly consisted of rather clean ice. Failure circumstances are particularly unclear to us for Aparejo and Leñas.

The angles of reach of the ice-rock avalanches associated with glacier detachments (Fahrböschung between about 5 and $10^{\circ}$ ), both absolutely and relative to their volume, are lower or at the lower end of those observed for other types of ice-rock avalanches (Fig. 1a, b). The particularly high ice content of glacier detachments might reduce the friction of the mass movements through liquefaction (Schneider et al., 2011), promoting the long runouts. Remarkably, many (perhaps all) detached glaciers appear to have sat on particularly fine-grained glacier beds. The large amounts of soft sediments under the glaciers with a potentially low friction angle combined with low effective pressure due to the presence of large amounts of basal water at the time of detachments may have been able to reach unusually low basal shear stress. In addition, smooth u-shaped glacial valleys might favour low angles of reach by channelizing the mass flows, reducing energy dissipation, and presenting few topographic obstacles along the path (Schneider et al., 2011). The glacier detachments' long runout flows remind also of rocky "sturzstroms", some of which reached friction angles $(H / L)$ as low as those found for the ice-rock avalanches from glacier detachments (Hsü, 1975). Sturzstroms and these ice-rock avalanches may share some physics, including reduced basal fraction from acoustic fluidization or movement on air or vapour cushions of flow materials. One mechanism for the long runout of dry granular flows involves acoustic fluidization (Gareth and Melosh, 2003), in which the physics analogue in the long runout ice-rock avalanches may be acoustic fluidization of ice, especially in cases when the role of liquid water was mainly restricted in producing the initial mobilization of the glacier detachment.

\subsection{Influence of climate change}

Inevitably, these events raise the question of whether climate change could be a driving factor of glacier detachments. Some cases investigated here suggest that detachments could be part of a cycle from reservoir refilling to occasional threshold exceedance, similar to what is found for glacier surges and some avalanching glaciers (Benn et al., 2019; Amney Machen, Tinguiririca, Devdorak, Kolka; uncertain: Rasht). But several cases of this study also illustrate developments when climate change can cause transient conditions that lead to failure. A number of dispositions and triggers listed in Fig. 22 may be impacted by climatic changes and may bring a glacier closer to failure or prevent future failures, respectively.

Repeated detachments of the same glacier, or detachments connected to surge-like behaviour, require that the climate conditions and associated glacier mass balances enable reservoir recovery or build-up of accumulation areas (Devdorak, Aru, Amney Machen, Kolka 1902). Climate change might shift glaciers out of the envelope of conditions that are favourable for surging or shift them into it (Hock et al., 2019). Whereas glacier rebuilding seems to be underway at Kolka and Aru, it is open for Sedongpu, unlikely for Tinguiririca, and did not happen at all for Tsambagarav. The glacier's potential to regain a substantial size is critically linked to the potential for repeated detachment events and thus important for hazard management.

The enhanced ice-rock avalanching onto Kolka Glacier in 2002, possibly responsible for its detachment, and the 2017 Gyala Peri rock avalanche over the Sedongpu Glacier are likely a reflection of a general trend of climate change impact on polythermal, glacierized rock walls, in which the reduction of ice cover and permafrost thaw increases the rock and ice fall frequency and enhances the potential for 
long-reaching cascading events (Fischer et al., 2013; Hock et al., 2019). Indeed, summers were exceptionally warm and glacier mass balances negative in the Caucasus Mountains, around Kolka Glacier, over 1998-2001 (Zemp et al., 2019). Glacier shrinkage due to negative mass balance (Larsen et al., 2015; Treichler et al., 2019; Zemp et al., 2019) has exposed large parts of the - in earlier times mostly ice-covered - headwalls of Flat Creek, Amney Machen, Leñas, and likely Petra Pervogo/Rasht. This exposes bedrock to erosion making it available for mass flows and incorporation in and underneath the glaciers, a process that is particularly important for soft rock lithologies. The partial loss of glacier cover may also interrupt existing patterns of stress transfer and cause new temporary stress concentrations (see also Fig. 20) that may exceed stability thresholds in certain locations. Some glacier detachments could thus be connected to the transient development of headwall glacier loss.

Climate change increases the amount of meltwater and transitions from snowfall to rainfall and may thus favour the development of instabilities, at least for the polythermal glaciers (Aru and Flat Creek; uncertain: Tsambagarav) where such amounts of meltwater are unusual at the scale of the last century. The relative increase in meltwater can be particularly significant for cold and dry climate glaciers. The synchronization of the twin Aru detachments within just 2 months of each other points to a climate-driven instability perhaps involving some meteorological synchronization such as exceptional amounts of high-elevation rain or snow and ice melt or extreme weather. Also, and without understanding the triggers of the Aru events in detail, the frequency and magnitude of certain potential climatic causes and meteorological trigger events, such as heavy rain falls or warm spells, can increase with climatic changes. All low-angle detachments found seemed to have occurred at partially or fully thawed beds and likely none where the glacier is completely frozen to its bed, thus possibly defining a rough climate and ice-thermal envelope for these detachments.

Also our simplified considerations on the force balance of a glacier slab (Sect. 4.1) provide hints to how climate change could influence detachments. For this strongly idealized geometry, the fast and extensive reduction of basal shear stress obviously reduces stability. An increase in glacier slope (e.g. from bulging), or thickness and density of the slab (e.g. additional loading from ice or rock avalanche deposition), faster than the glacier's ability to adjust will increase driving stress. Finally, climate change could also reduce the lateral shear stress, for instance, by the thawing of frozen glacier margins.

\subsection{Hazard management}

From a more applied hazard management perspective, sudden massive glacier detachments pose a high-magnitude and low-frequency problem, and their low-probability and highconsequence nature makes them hard to incorporate in hazard management and planning. The particularly low fric- tion coefficients $(H / L)$ involved in the detachments enable them to travel over low slopes (where other types of icerock avalanches would stall) and to cover large distances. The detachment events seem very rare, but their large volumes, fast evolution, and the exceptionally long runout distances and high speeds hold the potential for severe impacts even far away from the source. Our compilation of all (so far) known cases shows that low-angle glacier detachments might have, though rare, occurred more frequently than commonly thought. The differences between the events suggest that there is no straightforward way to predict where they might occur, but the following list of the most common conditions might support a more systematic assessment. Events happened at the following places:

i. with abundant weak bedrocks/fine sediments,

ii. where glacier surface slope is between about 10 and $20^{\circ}$,

iii. where surge-like glacier instabilities are observed in the region, sometimes for the detached glacier itself (exception: Tsambagarav), and

iv. where similar events or other violent ice-rock mass flows have happened before (based on direct observation or a geomorphological imprint).

This set of very rough qualitative criteria might allow a firstorder assessment of whether glacier detachments are possible in any given region. It is crucial to be aware, however, that these criteria and their interplay are likely transient so that in particular criterion (iv) can be misleading. Particularly important for hazard management is - yet again - the conclusion that climate change is able to shift hazard zones beyond historical precedence so that also so far unaffected areas might suddenly be susceptible (Hock et al., 2019).

For several of the events we find in aerial and satellite images streamlined debris features in the avalanche paths. Field investigations for Kolka Glacier (Petrakov et al., 2004) and Flat Creek (study in preparation) show ground traces related to the avalanche movement at two very different scales. Debris features of metres in width and tens or hundreds of metres length resemble glacial flutes but might also consist of pavements. These features can be recognized in high-resolution aerial and satellite images and are in this study in a general way called debris stripes, acknowledging that they are not investigated in detail or understood. At a much smaller scale (millimetre-centimetre in width, decimetre-metre in length) and thus not visible in aerial and satellite images, boulders in the avalanche path can show scratches in avalanche direction, similar to glacier striations. Notably, both scales of avalanche traces show that the ice-rock avalanches presented here were not entirely turbulent. More research is necessary to correctly interpret these signatures and differentiate them from glacial flutes, small 
moraines, and other longitudinal glacial and geomorphodynamic features.

Systematic monitoring turns out to be one of the most feasible responses to changes in hazard conditions, and the increasing temporal and spatial resolution, and improving availability of satellite imagery, is particularly helpful for glacier detachment assessment. For several of the cases in this contribution, abnormal glacier crevassing and accelerating precursory speeds were visible days to weeks before failure (Kolka 2002, Rasht, Aru, Sedongpu, Tsambagarav; uncertain: Flat Creek), but the significance of such a development was realized for the second Aru detachment only due to its spatial and temporal proximity to the first Aru detachment. On the other hand, abnormal crevassing does not necessarily indicate an impending detachment; see Rasht (situation in 2007; Supplement Fig. S2) or Leinss et al. (2019), in which the glacier geometry has likely stabilized a detaching ice mass. Overall, predicting glacier detachments can likely only be achieved by strong efforts in detailed remotesensing-based monitoring and, if feasible, by ground-based measurements, which contribute to an improved understanding of conditions and relevant processes, past events, glacier velocities and slope deformations, glacier bed geology and lithology, surge behaviour and dynamics, and short-term and long-term temperature and precipitation records (Kääb et al., 2018). Neglecting practical obstacles, events that repeat after a few years - Amney Machen, Flat Creek (?) - could be a suitable place to learn more about the governing physical processes by setting up detailed field investigations and monitoring facilities.

\section{Conclusions}

In this contribution we described around 20 ice-rock avalanche events that we characterize as sudden largevolume detachments of low-angle glaciers. Overall, these events seem to be more frequent than previously thought. The detached volumes ranged from a few up $10^{6} \mathrm{~m}^{3}$ to more than $100 \times 10^{6} \mathrm{~m}^{3}$. We described one new event in the same size-class as the 2002 Kolka and the 2016 Aru glacier detachments (Sedongpu 2018) and as a side-result quantified one of the larger high-mountain rock avalanches of recent decades (Gyala Peri 2017).

Despite the relatively low number of low-angle glacier detachments and their site-specific variations that leave considerable uncertainties, we were able to identify a set of conditions and evolutions likely involved in these glacier failures. We consider this an important step given that a few years ago the possibility for low-angle mountain glaciers to detach and produce massive ice-rock avalanches was hardly known. Interestingly, the fact that the spatio-temporal factor combinations leading to exceptionally low basal friction and very high shear stress concentration, and eventually to detachment, are different among the cases suggests that there exists an exceptional but still fundamental possibility of lowangle glacier beds to fail catastrophically. Awareness of this fundamental potential for catastrophic basal instability expands our understanding of glacier flow.

Many of the glacier detachments show some relation to surge-type glacier movement and could be seen as a rare and extreme endmember of this much more common glacier instability. Glacier detachments combine elements of surging, in which the glacier adjusts its geometry to satisfy the force balance, with those of ice break-offs from steeper glaciers, in which the glacier is not able to adjust in a steady way. The surface slopes of $9-21^{\circ}$ of the detached glacier parts, though quite low for glaciers that produce ice avalanches, might rank high in comparison with surge-type glacier tongues. Slopes in this range exert higher shear stresses than is typical for surge-type glaciers and favour thus the possibility of exceeding a critical stress level that then leads to sudden failure. At the same time, in comparison to glaciers in very steep terrain that tend to be thin, glaciers of $10-20^{\circ}$ surface slope can build up thicker ice which leads to the larger volumes typically involved in detachments. Using a strongly simplifying slab model, we estimate ranges for glacier slope and width above which a glacier could detach when widespread and strong loss of its basal resistance cannot be accommodated anymore by lateral resistance. We estimate a critical shear stress of $0.28 \mathrm{MPa}$ that could be supported by the glacier margins of the Aru detachments. We also estimate that (surge-like) precursory acceleration of glacier sliding before detachment could produce substantial amounts of ice melt at the glacier base that would facilitate the reduction of the shear stress of soft beds.

Weak bedrock and/or the existence of soft and highly erodible sediments under the detached glaciers was identified for most of the observed glacier detachments, was plausible for the ones we determined retroactively, and hints at till-strength weakening under high pore-water pressure as a concrete failure process. There appear to be different trajectories into, or out of, the narrow envelope of potential failure conditions, not least driven by climatic changes. The fact that most collapses happened during local spring/summer suggests that a meltwater or high-altitude rain-driven increase in basal pore water pressure can play an important role in triggering the events whether directly or in some delayed form. Atmospheric warming enhances such hazard conditions. For some detachment sites, negative regional glacier mass balances can prevent detached glaciers from fully rebuilding and thus detachments from repeating over time, at least at earlier volumes. All low-angle detachments found occurred where the climate allows a partially or fully thawed bed, and none seemed to have occurred where the glacier is completely frozen to its bed. The special case of Tsambagarav demonstrates that an earthquake was not able to trigger a glacier detachment (reinforcing earlier findings that low-slope glaciers appear quite resistant to ground shaking; Kargel et al., 2016) 
but to precondition one glacier for failure along a weakness existing already before the earthquake.

Detailed investigations of the events described in this study showed that a wide variety of dispositions and triggers can lead to a glacier detachment. This makes it challenging for practitioners working in high-mountain hazard management to anticipate and predict such events. From this practical standpoint, however, this study attempts to raise awareness about the - albeit low - possibility of sudden, largevolume detachments of low-angle glaciers at locations with the following characteristics:

- Lithologies are particularly soft and erodible.

- There is the existence of surge-type glaciers and surgelike glacier evolution, processes that are likely related to the soft lithologies.

- Repeated events or geomorphological imprints of potential earlier collapses or other violent ice-rock mass flows can be further investigated, but events can also happen without historical precedence through shifts in the array of failure conditions.

- Several of the glaciers investigated here showed abnormal crevassing and enhanced precursory surface speeds in the days to weeks before detachment.

- The surface slopes found in this study for the detached glaciers ranged between roughly 10 and $20^{\circ}$, and we propose a rough combination of glacier slope and width above which glaciers could detach in the case of extensive loss of basal friction (Sect. 4.1).

Due to the large amounts of snow and ice involved in glacier detachments, the high chance of lubrication and of liquefaction of glacier ice and subglacial sediments and smooth geometries of glacial valleys, avalanche friction is typically greatly reduced. This results in the particularly high mobility of the ice-rock avalanches resulting from low-angle glacier detachments and can lead to substantial damage far from the source. Between the large runout distances and the varying factors that can impact a glacier's detachment probability, high-mountain hazard management will, after the first general assessment provided in this study, benefit from more detailed investigations of glacier detachments, the conditions that lead to them, and the mechanics that drive them.

Data availability. Sentinel-1 and Sentinel-2 data are freely available from the ESA/EC Copernicus Sentinels Scientific Data Hub (Copernicus Open Access Hub, 2021), Landsat satellite data, Corona satellite data, and SRTM-C DEMs from the United States Geological Survey (EarthExplorer, 2021), SRTM-X and TanDEM$X$ DEMs from the German Aerospace Center (EOWEB GeoPortal, 2021), the ALOS World DEM from the Japan Aerospace Exploration Agency (JAXA, 2021), and Chinese earthquake data from the China Earthquake Data Center (2021). Planet data (Dove and
RapidEye) are not openly available as Planet is a commercial company. However, scientific access schemes to these data exist (https: //www.planet.com/markets/education-and-research/, last access: 7 April 2021). Data from Maxar satellites (GeoEye, Ikonos, WorldView, QuickBird) and Airbus (Pléiades, Spot) are commercial but in parts able to be explored in GoogleEarth and Bing Maps.

Supplement. The supplement related to this article is available online at: https://doi.org/10.5194/tc-15-1751-2021-supplement.

Author contributions. AK developed the concept of the paper, wrote most of the text, did most of the analyses, and prepared the figures. MJ wrote the Flat Creek section and revised all content and text. AG wrote the slab model section and other parts of the discussion section. SL, FP, SG, and EB contributed satellite data analyses. LG prepared the Sedongpu DEMs. CH contributed to the text and discussion on hazard management aspects. DP, SC, and MD contributed to the text and analysis on cases in the Caucasus Mountains and Central Asia. DF and FU contributed to the text and analysis of cases in South America. JK contributed fundamental ideas on deformable beds and soft sediments and to energy conservation analyses. All authors contributed with data and discussions and edited the manuscript.

Competing interests. The authors declare that they have no conflict of interest.

Acknowledgements. This paper is an extended and updated version of the Louis Agassiz medal lecture by Andreas Kääb given at the European Geosciences Union General Assembly 2019. We would like to thank Martin Truffer, an anonymous referee, and the editor Arjen Stroeven for their very constructive comments. The force balance model, Sect. 4.1, is based on a concept proposed to us by Martin Truffer. We are grateful to the providers of free data for this study: European Space Agency (ESA)/European Commission (EC) Copernicus for Sentinel-2 data, USGS for Landsat, Corona, and SRTM data, DLR for SRTM and TanDEM-X data, and Planet for their CubeSat data via Planet's Ambassadors Program. Etienne Berthier and Simon Gascoin acknowledge support from the French Space Agency (CNES) through TOSCA and DINAMIS programmes. Sergey Chernomorets acknowledges support from Lomonosov Moscow State University on the theme "Mapping, modeling and risk assessment of dangerous natural processes". Paola Banegas from SEGEMAR Mendoza provided the 1962 aerial photos over Tinguiririca.

Financial support. This work has been supported by the European Space Agency projects Permafrost_CCI (4000123681/18/INB), Glaciers_CCI (4000109873/14/I-NB, 4000127593/19/INS), and the ESA EarthExplorer10 Mission Advisory Group (4000127656/19/NL/FF/gp), by the European Research Council under the European Union's Seventh Framework Programme (FP/2007-2013)/ERC grant agreement no. 320816, and by the Russian Foundation for Basic Research (grant 18-05-00520). 
Jeffrey S. Kargel thanks NASA's Interdisciplinary Science Program (grant 80NSSC18K0432). Mikhail Dokukin acknowledges support by theme 6.3 .2 of the Roshydromet research and development plan no. AAAA-A20-120031990040-7.

Review statement. This paper was edited by Arjen Stroeven and reviewed by Martin Truffer and one anonymous referee.

\section{References}

Agatova, A. R., Nepop, R. K., Otgonbayar Demberel, and Ganyushkin, D. A.: The influence of the seismic process on the modern glaciation of the Tsambagarav massif (Western Mongolia), in: XVII Glaciological Symposium, St. Petersburg, Russia, 17-20 November 2020, p. 15, 2020.

Alean, J.: Ice avalanche activity and mass balance of high-altitude hanging glaciers in the Swiss Alps, Ann. Glaciol., 6, 248-249, 1985.

Aristov, K. A., Petrakov, D. A., Kovalenko, N. V., Timonin, S. A., Kolchin, A. A., and Drobyshev, V. N.: Monitoring of Kolka Glacier in 2014-2017 by terrestrial stereophotogrammetry, Journal Ice and Snow, 59, 49-58, https://doi.org/10.15356/20766734-2019-1-49-58, 2019 (in Russian).

Avdeev, V. A., Nartov, S. V., Baljinniam, I., Monhoo, D., and Erdenbileg, B.: Tsambagarav earthquake of 23 July 1988, Geology and Geophysics, 11, 118-124, 1989 (in Russian).

Benn, D. I., Fowler, A. C., Hewitt, I., and Sevestre, H.: A general theory of glacier surges, J. Glaciol., 65, 701-716, https://doi.org/10.1017/jog.2019.62, 2019.

Braun, M. H., Malz, P., Sommer, C., Farias-Barahona, D., Sauter, T., Casassa, G., Soruco, A., Skvarca, P., and Seehaus, T. C.: Constraining glacier elevation and mass changes in South America, Nat. Clim. Change, 9, 130-136, https://doi.org/10.1038/s41558018-0375-7, 2019.

Brenning, A.: Geomorphological, hydrological and climatic significance of rock glaciers in the Andes of Central Chile $\left(33-35^{\circ} \mathrm{S}\right)$, Permafrost Periglac., 16, 231-240, https://doi.org/10.1002/ppp.528, 2005.

Brun, F., Berthier, E., Wagnon, P., Kääb, A., and Treichler, D.: A spatially resolved estimate of High Mountain Asia glacier mass balances from 2000 to 2016, Nat. Geosci., 10, 668-673, https://doi.org/10.1038/ngeo2999, 2017.

Caplan-Auerbach, J. and Huggel, C.: Precursory seismicity associated with frequent, large ice avalanches on Iliamna volcano, Alaska, USA, J. Glaciol., 53, 128-140, https://doi.org/10.3189/172756507781833866, 2007.

Chen, C., Zhang, L. M., Xiao, T., and He, J.: Barrier lake bursting and flood routing in the Yarlung Tsangpo Grand Canyon in October 2018, J. Hydrol., 583, 124603, https://doi.org/10.1016/j.jhydrol.2020.124603, 2020.

Chernomorets, S. S.: New "Kazbek blockage" on 17 May 2014, Priroda, 7: 67-72, available at: https://istina.msu.ru/download/ 6618200/1k5k5t:82mOHGauqEFijKJOHSXRsTVDIT8/ (last access: 7 April 2021), 2014 (in Russian).

Chernomorets, S. S., Tutubalina, O. V., Seinova, I. B., Petrakov, D. A., Nosov, K. N., and Zaporozhchenko, E. V.: Glacier and debris flow disasters around Mt. Kazbek, Russia/Georgia, in: Debris-
Flow Hazards Mitigation: Mechanics, Prediction, and Assessment, edited by: Chen, C. L. and Major, J. J., Millpress, The Netherlands, 2007.

Chernomorets, S. S., Savernyuk, E., Petrakov, D., Dokukin, M., Gotsiridze, G., Gavardashvili, G., Drobyshev, V., Tutubalina, O., Zaporozhchenko, E., Kamenev, N., Kamenev, V., Kääb, A., Kargel, J., and Huggel, C.: The Devdorak ice-rock avalanche and consequent debris flow from the slope of Mt. Kazbek (Caucasus, Georgia) in 2014, in: EGU General Assembly Conference Abstracts, 1 April 2016, Vienna, Austria, 2016.

China Earthquake Data Center: available at: http://data.earthquake. cn/index.html, last access: 7 April 2021.

Clarke, G. K. C. and Blake, E. W.: Geometric and thermal evolution of a surge-type glacier in its quiescent state - Trapridge Glacier, Yukon-Territory, Canada, 1969-1989, J. Glaciol., 37, 158-169, 1991.

Clarke, G. K. C., Collins, S. G., and Thompson, D. E.: Flow, thermal structure, and subglacial conditions of a surge-type glacier, Can. J. Earth Sci., 21, 232-240, https://doi.org/10.1139/e84-024, 1984.

Copernicus Open Access Hub: Copernicus programme, European Commission and European Space Agency, available at: https:// scihub.copernicus.eu, last access: 7 April 2021.

Cuffey, K. and Paterson, W. S. B.: The physics of glaciers, 4th Edn., Butterworth-Heinemann, Burlington and Oxford, 2010.

Dokukin, M. D., Bekkiev, M. Y., Kalov, R. H., Savernyuk, E. A., and Chernomorets, S. S.: Signs of catastrophic glacier detachments (Analysis of multitemporal space information), in: Dangerous natural and technogenic processes in mountain regions: models, systems and technologies, edited by: Nikolaev, A. and Zaalishvili, V., Vladikavkaz, 522-528, available at: https: //istina.msu.ru/publications/article/266605247/, (last access: 7 April 2021), 2019 (in Russian).

Dokukin, M. D., Bekkiev, M. Y., Kalov, R. K., Chernomorets, S. S., and Savernyuk, E. A. Activation of rock avalanches in the Central Caucasus and their impact on the dynamics of glaciers and debris flows, Journal Ice and Snow, 60, 361-378, 2020.

Drobyshev, V. N.: Glacial catastrophe of 20 September 2002 in North Osetia, Russian J. Earth Sci., 8, ES4004, https://doi.org/10.2205/2006ES000207, 2006.

Dunse, T., Schellenberger, T., Hagen, J. O., Kääb, A., Schuler, T. V., and Reijmer, C. H.: Glacier-surge mechanisms promoted by a hydro-thermodynamic feedback to summer melt, The Cryosphere, 9, 197-215, https://doi.org/10.5194/tc-9-197-2015, 2015.

Dussaillant, I., Berthier, E., Brun, F., Masiokas, M., Hugonnet, R., Favier, V., Rabatel, A., Pitte, P., and Ruiz, L.: Two decades of glacier mass loss along the Andes, Nat. Geosci., 12, 803, https://doi.org/10.1038/s41561-019-0432-5, 2019.

EarthExplorer: United States Geological Survey, available at: https: //earthexplorer.usgs.gov/, last access: 7 April 2021.

EOWEB GeoPortal: German Aerospace Center, available at: https: //eoweb.dlr.de/egp/, last access: 7 April 2021.

Evans, S. G. and Delaney, K. B.: Catastrophic mass flows in the mountain glacial environment, in: Snow and Ice-related Hazards, Risks, and Disasters, edited by: Haeberli, W. and Whitemann, C., Hazards and Disasaters Series, Elsevier, Amsterdam, The Netherlands, 563-606, https://doi.org/10.1016/B978-0-12394849-6.00016-0, 2015. 
Evans, S. G., Bishop, N. F., Smoll, L. F., Murillo, P. V., Delaney, K. B., and Oliver-Smith, A.: A re-examination of the mechanism and human impact of catastrophic mass flows originating on Nevado Huascaran, Cordillera Blanca, Peru in 1962 and 1970, Eng. Geol., 108, 96-118, https://doi.org/10.1016/j.enggeo.2009.06.020, 2009a.

Evans, S. G., Tutubalina, O. V., Drobyshev, V. N., Chernomorets, S. S., McDougall, S., Petrakov, D. A., and Hungr, O.: Catastrophic detachment and high-velocity long-runout flow of Kolka Glacier, Caucasus Mountains, Russia in 2002, Geomorphology, 105, 314-321, https://doi.org/10.1016/j.geomorph.2008.10.008, 2009b.

Faillettaz, J., Sornette, D., and Funk, M.: Numerical modeling of a gravity-driven instability of a cold hanging glacier: reanalysis of the 1895 break-off of Altelsgletscher, Switzerland, J. Glaciol., 57, 817-831, 2011.

Faillettaz, J., Funk, M., and Vincent, C.: Avalanching glacier instabilities: Review on processes and early warning perspectives, Rev. Geophys., 53, 203-224, https://doi.org/10.1002/2014rg000466, 2015.

Falaschi, D., Bolch, T., Lenzano, M. G., Tadono, T., Lo Vecchio, A., and Lenzano, L.: New evidence of glacier surges in the Central Andes of Argentina and Chile, Prog. Phys. Geog., 42, 792-825, https://doi.org/10.1177/0309133318803014, 2018a.

Falaschi, D., Lenzano, M. G., Tadono, T., Vich, A., and Lenzano, L.: Balance de masa geodésico 2000-2011 de los glaciares de la cuenca del río Atuel, Andes Centrales de Mendoza, Geoacta, 42, 7-22, 2018b.

Falaschi, D., Kääb, A., Paul, F., Tadono, T., Rivera, J. A., and Lenzano, L. E.: Brief communication: Collapse of $4 \mathrm{Mm} 3$ of ice from a cirque glacier in the Central Andes of Argentina, The Cryosphere, 13, 997-1004, https://doi.org/10.5194/tc-13997-2019, 2019.

Fischer, L., Huggel, C., Kääb, A., and Haeberli, W.: Slope failures and erosion rates on a glacierized high-mountain face under climatic changes, Earth Surf. Proc. Land., 38, 836-846, https://doi.org/10.1002/Esp.3355, 2013.

Flowers, G. E., Jarosch, A. H., Belliveau, P. T. A. P., and Fuhrman, L. A.: Short-term velocity variations and sliding sensitivity of a slowly surging glacier, Ann. Glaciol., 57, 71-83, https://doi.org/10.1017/aog.2016.7, 2016.

Fowler, A. C., Murray, T., and Ng, F. S. L.: Thermally controlled glacier surging, J. Glaciol., 47, 527-538, https://doi.org/10.3189/172756501781831792, 2001.

Frappe, T. P. and Clarke, G. K. C.: Slow surge of Trapridge Glacier, Yukon territory, Canada, J. Geophys. Res.-Earth, 112, F03s32, https://doi.org/10.1029/2006jf000607, 2007.

Gardelle, J., Berthier, E., Arnaud, Y., and Kääb, A.: Regionwide glacier mass balances over the Pamir-KarakoramHimalaya during 1999-2011, The Cryosphere, 7, 1263-1286, https://doi.org/10.5194/tc-7-1263-2013, 2013.

Gareth, G. S. and Melosh, H. J.: Acoustic fluidization and the extraordinary mobility of sturzstroms, J. Geophys. Res.-Earth, 108, 2473, https://doi.org/10.1029/2003JB002465, 2003.

Gilbert, A., Leinss, S., Kargel, J., Kääb, A., Gascoin, S., Leonard, G., Berthier, E., Karki, A., and Yao, T.: Mechanisms leading to the 2016 giant twin glacier collapses, Aru Range, Tibet, The Cryosphere, 12, 2883-2900, https://doi.org/10.5194/tc-12-28832018, 2018.
Goerlich, F., Bolch, T., and Paul, F.: More dynamic than expected: an updated survey of surging glaciers in the Pamir, Earth Syst. Sci. Data, 12, 3161-3176, https://doi.org/10.5194/essd-12-31612020, 2020.

Gruber, F. E. and Mergili, M.: Regional-scale analysis of highmountain multi-hazard and risk indicators in the Pamir (Tajikistan) with GRASS GIS, Nat. Hazards Earth Syst. Sci., 13, 27792796, https://doi.org/10.5194/nhess-13-2779-2013, 2013.

Haeberli, W., Kääb, A., Paul, F., Chiarle, M., Mortara, G., Mazza, A., and Richardson, S.: A surge-type movement at Ghiacciaio del Belvedere and a developing slope instability in the east face of Monte Rosa, Macugnaga, Italian Alps, Nor. J. Geogr., 56, 104111, 2002.

Haeberli, W., Huggel, C., Kääb, A., Zgraggen-Oswald, S., Polkvoj, A., Galushkin, I., Zotikov, I., and Osokin, N.: The Kolka-Karmadon rock/ice slide of 20 September 2002: an extraordinary event of historical dimensions in North Ossetia, Russian Caucasus, J. Glaciol., 50, 533-546, https://doi.org/10.3189/172756504781829710, 2004.

Harrison, W. D. and Post, A. S.: How much do we really know about glacier surging?, Ann. Glaciol., 36, 1-6, https://doi.org/10.3189/172756403781816185, 2003.

Harrison, W. D., Osipova, G. B., Nosenko, G. A., Espizua, L., Kääb, A., Fischer, L., Huggel, C., Craw Burns, P. A., Truffer, M., and Lai, A. W.: Glacier Surges, in: Snow and Ice-related Hazards, Risks, and Disasters, edited by: Haeberli, W. and Whitemann, C., Elsevier, Amsterdam, The Netherlands, 437-485, 2015.

Hauser, A.: Rock avalanche and resulting debris flow in Estero Parraguirre and Río Colorado, Región Metropolitana, Chile, in: Catastrophic Landslides: Effects, Occurrence, and Mechanisms, edited by: Evans, S. G. and DeGraff, J. V., Geological Society of America Reviews in Engineering Geology 15, Boulder, Colorado, USA, 135-148, 2002.

Herreid, S. and Truffer, M.: Automated detection of unstable glacier flow and a spectrum of speedup behavior in the Alaska Range, J. Geophys. Res.-Earth, 121, 64-81, https://doi.org/10.1002/2015jf003502, 2016.

Hock, R., Rasul, G., Adler, C., Cáceres, B., Gruber, S., Hirabayashi, Y., Jackson, M., Kääb, A., Kang, S., Kutuzov, S., Milner, A., Molau, U., Morin, S., Orlove, B., and Steltzer, H.: High Mountain Areas, in: IPCC, Special Report on the Ocean and Cryosphere in a Changing Climate (SROCC), edited by: Pörtner, H.-O., Roberts, D. C., Masson-Delmotte, V., Zhai, P., Tignor, M., Poloczanska, E., Mintenbeck, E., Alegriìa, A., Nicolai, M., Okem, A., Petzold, J., Rama, B., and Weyer, N. M., The Intergovernmental Panel on Climate Change (IPCC), Geneva, Switzerland, 2019.

Hoinkes, H.: Die Ausbrüche (surges) des Kolka-Gletschers in NordOssetien, Zentraler Kaukasus, Z. Gletscherkd. Glazial-Geol., 253-270, 1972 (in German).

Hsü, K. J.: Catastrophic debris streams (Sturzstroms) generated by rockfalls, Geol. Soc. Am. Bull., 86, 129-140, 1975.

Hu, K. H., Zhang, X. P., You, Y., Hu, X. D., Liu, W. M., and Li, Y.: Landslides and dammed lakes triggered by the 2017 Ms6.9 Milin earthquake in the Tsangpo gorge, Landslides, 16, 9931001, https://doi.org/10.1007/s10346-019-01168-w, 2019.

Huggel, C.: Recent extreme slope failures in glacial environments: effects of thermal perturbation, Quaternary Sci. Rev., 28, 11191130, https://doi.org/10.1016/j.quascirev.2008.06.007, 2009. 
Huggel, C., Zgraggen-Oswald, S., Haeberli, W., Kääb, A., Polkvoj, A., Galushkin, I., and Evans, S. G.: The 2002 rock/ice avalanche at Kolka/Karmadon, Russian Caucasus: assessment of extraordinary avalanche formation and mobility, and application of QuickBird satellite imagery, Nat. Hazards Earth Syst. Sci., 5, 173-187, https://doi.org/10.5194/nhess-5-173-2005, 2005.

Huggel, C., Caplan-Auerbach, J., Waythomas, C. F., and Wessels, R. L.: Monitoring and modeling ice-rock avalanches from icecapped volcanoes: A case study of frequent large avalanches on Iliamna Volcano, Alaska, J. Volcanol. Geoth. Res., 168, 114-136, https://doi.org/10.1016/j.jvolgeores.2007.08.009, 2007.

Iribarren Anacona, P., Mackintosh, A., and Norton, K. P.: Hazardous processes and events from glacier and permafrost areas: lessons from the Chilean and Argentinean Andes, Earth Surf. Proc. Land., 40, 2-21, https://doi.org/10.1002/esp.3524, 2015.

Jacquemart, M. and Loso, M.: Catastrophic glacier collapse and debris flow at Flat Creek, Wrangell-St. Elias National Park and Preserve, Alaska Park Science, 18, 16-25, 2019.

Jacquemart, M., Loso, M., Leopold, M., Welty, E., Berthier, E., Hansen, J. S. S., Sykes, J., and Tiampo, K.: What drives large-scale glacier detachments? Insights from Flat Creek glacier, St. Elias Mountains, Alaska, Geology, 48, 703-707, https://doi.org/10.1130/g47211.1, 2020.

Japan Aerospace Exploration Agency (JAXA): ALOS World 3D, Earth Observation Research Center, available at: https://www. eorc.jaxa.jp/ALOS/en/aw3d30/index.htm, last access: 7 April 2021.

Jiskoot, H.: Glacier surging, in: Encyclopedia of Snow, Ice and Glaciers, edited by: Singh, V. P. and Haritashya, U. K., Springer, 415-428, 2011.

Kääb, A.: Collapsing Glaciers, Geophys. Res. Abstr., 21, 8799, European Geosciences Union General Assembly 2019, Vienna, Austria, 7-12 April 2019, 2019.

Kääb, A., Wessels, R., Haeberli, W., Huggel, C., Kargel, J., and Khalsa, S. J. S.: Rapid ASTER imaging facilitates timely assessment of glacier hazards and disasters, EOS Trans. AGU, 84, $117-$ 121, https://doi.org/10.1029/2003EO130001, 2003.

Kääb, A., Huggel, C., Barbero, S., Chiarle, M., Cordola, M., Epifani, F., Haeberli, W., Mortara, G., Semino, P., Tamburini, A., and Viazzo, G.: Glacier hazards at Belvedere Glacier and the Monte Rosa east face, Italian Alps: processes and mitigation, Interpraevent, 1, 67-78, available at: http://www.interpraevent.at/palm-cms/upload_files/ Publikationen/Tagungsbeitraege/2004_1_I-67.pdf (last access: 7 April 2021), 2004.

Kääb, A., Treichler, D., Nuth, C., and Berthier, E.: Brief Communication: Contending estimates of 2003-2008 glacier mass balance over the Pamir-Karakoram-Himalaya, The Cryosphere, 9, 557564, https://doi.org/10.5194/tc-9-557-2015, 2015.

Kääb, A., Leinss, S., Gilbert, A., Buhler, Y., Gascoin, S., Evans, S. G., Bartelt, P., Berthier, E., Brun, F., Chao, W. A., Farinotti, D., Gimbert, F., Guo, W. Q., Huggel, C., Kargel, J. S., Leonard, G. J., Tian, L. D., Treichler, D., and Yao, T. D.: Massive collapse of two glaciers in western Tibet in 2016 after surge-like instability, Nat. Geosci., 11, 114-120, https://doi.org/10.1038/s41561-0170039-7, 2018.

Kamb, B.: Glacier surge mechanism based on linked cavity configuration of the basal water conduit system, J. Geophys. Res.-Sol.
Ea., 92, 9083-9100, https://doi.org/10.1029/Jb092ib09p09083, 1987.

Kargel, J. S., Leonard, G. J., Shugar, D. H., Haritashya, U. K., Bevington, A., Fielding, E. J., Fujita, K., Geertsema, M., Miles, E. S., Steiner, J., Anderson, E., Bajracharya, S., Bawden, G. W., Breashears, D. F., Byers, A., Collins, B., Dhital, M. R., Donnellan, A., Evans, T. L., Geai, M. L., Glasscoe, M. T., Green, D., Gurung, D. R., Heijenk, R., Hilborn, A., Hudnut, K., Huyck, C., Immerzeel, W. W., Jiang, L. M., Jibson, R., Kääb, A., Khanal, N. R., Kirschbaum, D., Kraaijenbrink, P. D. A., Lamsal, D., Liu, S. Y., Lv, M. Y., McKinney, D., Nahirnick, N. K., Nan, Z. T., Ojha, S., Olsenholler, J., Painter, T. H., Pleasants, M., Pratima, K. C., Yuan, Q. I., Raup, B. H., Regmi, D., Rounce, D. R., Sakai, A., Donghui, S., Shea, J. M., Shrestha, A. B., Shukla, A., Stumm, D., van der Kooij, M., Voss, K., Xin, W., Weihs, B., Wolfe, D., Wu, L. Z., Yao, X. J., Yoder, M. R., and Young, N.: Geomorphic and geologic controls of geohazards induced by Nepal's 2015 Gorkha earthquake, Science, 351, aac8353, https://doi.org/10.1126/science.aac8353, 2016.

Kochtitzky, W., Jiskoot, H., Copland, L., Enderlin, E., Mcnabb, R., Kreutz, K., and Main, B.: Terminus advance, kinematics and mass redistribution during eight surges of Donjek Glacier, St. Elias Range, Canada, 1935 to 2016, J. Glaciol., 65, 565-579, https://doi.org/10.1017/jog.2019.34, 2019.

Kotlyakov, V. M., Rototaeva, O. V., and Nosenko, G. A.: The September 2002 Kolka glacier catastrophe in North Ossetia, Russian Federation, Evidence and analysis, Mt. Res. Dev., 24, 78-83, 2004.

Kotlyakov, V. M., Osipova, G. B., and Tsvetkov, D. G.: Monitoring surging glaciers of the Pamirs, central Asia, from space, Ann. Glaciol., 48, 125-134, https://doi.org/10.3189/172756408784700608, 2008.

Kotlyakov, V. M., Osipova, G. B., and Tsvetkov, D. G.: Investigations of the fluctuations of surge-type glaciers in the Pamir based on observations from space, in: Glaciers of Asia, U.S. Geological Survey Professional Paper 1386, edited by: Williams, R. S. J. and Ferrigno, J. G., USGS, Washington, 77-93, https://doi.org/10.3133/pp1386, 2010a.

Kotlyakov, V. M., Rototaeva, O. V., and Nosenko, G. A.: Fluctuations of glaciers of the Central Caucasus and Gora El'brus, with a section on the glaciological disaster in North Osetiya, in: Glaciers of Asia, U.S. Geological Survey Professional Paper 1386, edited by: Williams, R. S. J. and Ferrigno, J. G., USGS, 59-76, 2010b.

Kutuzov, S., Lavrentiev, I., Smimov, A., Nosenko, G., and Petrakov, D.: Volume changes of Elbrus glaciers from 1997 to 2017, Front. Earth Sci., 7, 153, https://doi.org/10.3389/feart.2019.00153, 2019.

Larsen, C. F., Burgess, E., Arendt, A. A., O’Neel, S., Johnson, A. J., and Kienholz, C.: Surface melt dominates Alaska glacier mass balance, Geophys. Res. Lett., 42, 5902-5908, https://doi.org/10.1002/2015gl064349, 2015.

Lei, Y., Yao, T., Tian, L., Sheng, Y., Lazhu, Liao, J., Zhao, H., Yang, W., Yang, K., Berthier, E., Brun, F., Gao, Y., Zhu, M., and Wu, G.: Response of downstream lakes to Aru glacier collapses on the western Tibetan Plateau, The Cryosphere, 15, 199-214, https://doi.org/10.5194/tc-15-199-2021, 2021.

Leinss, S., Willimann, C., and Hajnsek, I.: Glacier detachment hazard analysis in the West Kunlun Shan Mountains, 
IGARSS 2019, 2019 IEEE International Geoscience and Remote Sensing Symposium, Yokohama, Japan, 4565-4568, https://doi.org/10.1109/IGARSS.2019.8900320, 2019.

Leinss, S., Bernardini, E., Jacquemart, M., and Dokukin, M.: Glacier detachments and rock-ice avalanches in the Petra Pervogo range, Tajikistan (1973-2019), Nat. Hazards Earth Syst. Sci. Discuss. [preprint], https://doi.org/10.5194/nhess-2020-285, in review, 2020.

Liu, C. Z., Lu, J. T., Tong, L. Q., Chen, H. Q., Liu, Q. Q., Xiao, R. H., and Tu, J. N.: Research on glacial/rock fall-landslide-debris flows in Sedongpu basin along Yarlung Zangbo River in Tibet, Geol. China, 46, 219-234, 2019.

Lv, M., Guo, H., Lu, X., Liu, G., Yan, S., Ruan, Z., Ding, Y., and Quincey, D. J.: Characterizing the behaviour of surgeand non-surge-type glaciers in the Kingata Mountains, eastern Pamir, from 1999 to 2016, The Cryosphere, 13, 219-236, https://doi.org/10.5194/tc-13-219-2019, 2019.

Marangunic, C.: Informe sobre deslizamientos de glaciares en el Estero del Aparejo, Valle del Río Maipo, Área Metropolitana, Oficina Nacional de Emergencias, Santiago, Chile, 8 pp., 1980 (in Spanish).

Masiokas, M. H., Christie, D. A., Le Quesne, C., Pitte, P., Ruiz, L., Villalba, R., Luckman, B. H., Berthier, E., Nussbaumer, S. U., González-Reyes, Á., McPhee, J., and Barcaza, G.: Reconstructing the annual mass balance of the Echaurren Norte glacier (Central Andes, $33.5^{\circ} \mathrm{S}$ ) using local and regional hydroclimatic data, The Cryosphere, 10, 927-940, https://doi.org/10.5194/tc10-927-2016, 2016.

McClung, D. M.: Superelevation of flowing avalanches around curved channel bends, J. Geophys. Res.-Sol. Ea., 106, 1648916498, https://doi.org/10.1029/2001jb000266, 2001.

Mergili, M., Kopf, C., Mullebner, B., and Schneider, J. F.: Changes of the cryosphere and related geohazards in the high-mountain areas of Tajikistan and Austria: a comparison, Geogr. Ann. A, 94, 79-96, https://doi.org/10.1111/j.1468-0459.2011.00450.x, 2012.

Milana, J. P.: A model of the Glaciar Horcones Inferior surge, Aconcagua region, Argentina, J. Glaciol., 53, 565-572, https://doi.org/10.3189/002214307784409324, 2007.

Moore, P. L.: Deformation of debris-ice mixtures, Rev. Geophys., 52, 435-467, https://doi.org/10.1002/2014rg000453, 2014.

Murray, T., Strozzi, T., Luckman, A., Jiskoot, H., and Christakos, P.: Is there a single surge mechanism? Contrasts in dynamics between glacier surges in Svalbard and other regions, J. Geophys. Res.-Sol. Ea., 108, 2237, https://doi.org/10.1029/2002JB001906, 2003.

Obu, J., Westermann, S., Bartsch, A., Berdnikov, N., Christiansen, H. H., Dashtseren, A., Delaloye, R., Elberling, B., Etzelmuller, B., Kholodov, A., Khomutov, A., Kääb, A., Leibman, M. O., Lewkowicz, A. G., Panda, S. K., Romanovsky, V., Way, R. G., Westergaard-Nielsen, A., Wu, T. H., Yamkhin, J., and Zou, D. F.: Northern Hemisphere permafrost map based on TTOP modelling for 2000-2016 at $1 \mathrm{~km}^{2}$ scale, Earth-Sci. Rev., 193, 299-316, https://doi.org/10.1016/j.earscirev.2019.04.023, 2019.

Paul, F.: Repeat glacier collapses and surges in the Amney Machen mountain range, Tibet, possibly triggered by a developing rock-slope instability, Remote Sens.-Basel, 11, 708, https://doi.org/10.3390/rs11060708, 2019.

Pavez, C., Tapia, F., Comte, D., Gutierrez, F., Lira, E., Charrier, R., and Benavente, O.: Characterization of the hy- drothermal system of the Tinguiririca Volcanic Complex, Central Chile, using structural geology and passive seismic tomography, J. Volcanol. Geoth. Res., 310, 107-117, https://doi.org/10.1016/j.jvolgeores.2015.11.018, 2016.

Petrakov, D. A., Tutubalina, O. V., and Chernomorets, S. S.: The 2002 Genaldon glacial catastrophe: one year later, Earth's Cryosphere (Kriosfera Zemli), 8, 29-39, 2004.

Petrakov, D. A., Chernomorets, S. S., Evans, S. G., and Tutubalina, O. V.: Catastrophic glacial multi-phase mass movements: a special type of glacial hazard, Adv. Geosci., 14, $211-$ 218, https://doi.org/10.5194/adgeo-14-211-2008, 2008.

Petrakov, D. A., Aristov, K. A., Aleynikov, A. A., Boyko, E. S., Drobyshev, V. N., Kovalenko, N. V., Tutubalina, O. V., and Chernomorets, S. S.: Rapid regeneration of the Kolka Glacier (Caucasus) after the 2002 glacial disaster, Earth's Cryosphere (Kriosfera Zemli), 22, 51-62, https://doi.org/10.21782/EC2541-9994-20181(51-62), 2018.

Post, A.: Effects on Glaciers, in: The great Alaska earthquake of 1964, Part A: hydrology, National Academy of Sciences, Washington D.C., USA, 266-308, 1968.

Quincey, D. J., Glasser, N. F., Cook, S. J., and Luckman, A.: Heterogeneity in Karakoram glacier surges, J. Geophys. Res.-Earth, 120, 1288-1300, https://doi.org/10.1002/2015jf003515, 2015.

RGI Consortium: Randolph Glacier Inventory - A Dataset of Global Glacier Outlines: Version 6.0: Technical Report, Global Land Ice Measurements from Space, Digital Media, Colorado, USA, https://doi.org/10.7265/N5-RGI-60, 2017.

Rototayev, K. P., Khodakov, V. G., and Krenke, A. N.: Study of the Surging Kolka Glacier, Nauka, Moscow, 168 pp., 1983 (in Russian).

Schneider, D., Huggel, C., Haeberli, W., and Kaitna, R.: Unraveling driving factors for large rock-ice avalanche mobility, Earth Surf. Proc. Land., 36, 1948-1966, https://doi.org/10.1002/esp.2218, 2011.

Sevestre, H. and Benn, D. I.: Climatic and geometric controls on the global distribution of surge-type glaciers: Implications for a unifying model of surging, J. Glaciol., 61, 646-662, https://doi.org/10.3189/2015JoG14J136, 2015.

Sevestre, H., Benn, D. I., Hulton, N. R. J., and Baelum, K.: Thermal structure of Svalbard glaciers and implications for thermal switch models of glacier surging, J. Geophys. Res.-Earth, 120, 2220 2236, https://doi.org/10.1002/2015jf003517, 2015.

Shean, D. E., Bhushan, S., Montesano, P., Rounce, D. R., Arendt, A., and Osmanoglu, B.: A systematic, regional assessment of High Mountain Asia glacier mass balance, Front. Earth Sci., 7, 363, https://doi.org/10.3389/feart.2019.00363, 2020.

Shugar, D. H., Rabus, B. T., Clague, J. J., and Capps, D. M.: The response of Black Rapids Glacier, Alaska, to the Denali earthquake rock avalanches, J. Geophys. Res.-Earth, 117, F01006, https://doi.org/10.1029/2011jf002011, 2012.

Strom, A. and Abdrakhmatov, K.: Rockslides and Rock Avalanches of Central Asia: Distribution, Morphology, and Internal Structure, Elsevier, Amsterdam, The Netherlands, 2018.

Thogersen, K., Gilbert, A., Schuler, T. V., and Malthe-Sorenssen, A.: Rate-and-state friction explains glacier surge propagation, Nat. Commun., 10, 2823, https://doi.org/10.1038/s41467-01910506-4, 2019.

Tian, L. D., Yao, T. D., Gao, Y., Thompson, L., Mosley-Thompson, E., Muhammad, S., Zong, J. B., Wang, C., Jin, S. Q., and Li, Z. 
G.: Two glaciers collapse in western Tibet, J. Glaciol., 63, 194197, https://doi.org/10.1017/jog.2016.122, 2017.

Tielidze, L. G., Kumladze, R. M., Wheate, R. D., and Gamkrelidze, M.: The Devdoraki glacier catastrophes, Georgian Caucasus, Hungarian Geographical Bulletin, 68, 21-35, https://doi.org/10.15201/hungeobull.68.1.2, 2019.

Toney, L., Fee, D., Allstadt, K. E., Haney, M., and Matoza, R. S.: Reconstructing the dynamics of the highly-similar May 2016 and June 2019 Iliamna Volcano, Alaska ice-rock avalanches from seismoacoustic data, Earth Surf. Dynam. Discuss. [preprint], https://doi.org/10.5194/esurf-2020-47, in review, 2020.

Tong, L. Q., Tu, J. N., Pei, L. X., Guo, Z. C., Zheng, X. W., Fan, J. H., Zhong, X., Liu, C. L., Wang, S. S., He, P., and Chen, H.: Preliminary discussion of the frequent debris flow events in Sedongpu Basin at Gyala Peri peak, Yarlung Zangbo River, J. Eng. Geol., 26, 1552-1561, https://doi.org/10.13544/j.cnki.jeg.2018401, 2018.

Treichler, D., Kääb, A., Salzmann, N., and Xu, C.-Y.: Recent glacier and lake changes in High Mountain Asia and their relation to precipitation changes, The Cryosphere, 13, 2977-3005, https://doi.org/10.5194/tc-13-2977-2019, 2019.

Truffer, M., Harrison, W. D., and Echelmeyer, K. A.: Glacier motion dominated by processes deep in underlying till, J. Glaciol., 46, 213-221, https://doi.org/10.3189/172756500781832909, 2000.

Truffer, M., Harrison, W. D., Osipova, G. B., Nosenko, G. A., Espizua, L., Kääb, A., Gilbert, A., Fischer, L., Huggel, C., Craw Burns, P. A., and Lai, A. W.: Glacier Surges, in: Snow and Icerelated Hazards, Risks, and Disasters, edn. 2, edited by: Haeberli, W. and Whitemann, C., Elsevier, Amsterdam, The Netherlands, https://doi.org/10.1016/B978-0-12-817129-5.00003-2, 417-466, 2021.

Ugalde, F., Casassa, G., Marangunic, C., Mujica, R., and Peralta, C.: El deslizamiento catastrófico del glaciar Aparejo: 35 años después, in: XiV Congreso Geologico Chileno, 4-8 October 2015, La Serena, 2, 686-689, 2015.

Ugalde, F., Marangunic, C., and Casassa, G.: Ice thickness changes at Aparejo Glacier in central Chile from interferometric satellite data, First IEEE International Symposium of Geoscience and Remote Sensing (GRSS-CHILE), 15-16 June 2017, Valdivia, 2017, 1-4, https://doi.org/10.1109/GRSSCHILE.2017.7996013, . 2017

Ugalde, F. I. P.: Estimacíon de pelegro ante deslizamiento de glaciares en Chile Central: El caso del glaciar Aparejo. Departamento de Geología, Facultad de Ciencias Físicas y Matemáticas, Universidad de Chile, Santiago de Chile, 2016. van der Woerd, J., Owen, L. A., Tapponnier, P., Xu, X. W., Kervyn, F., Finkel, R. C., and Barnard, P. L.: Giant, similar to M8 earthquake-triggered ice avalanches in the eastern Kunlun Shan, northern Tibet: Characteristics, nature and dynamics, Geol. Soc. Am. Bull., 116, 394-406, https://doi.org/10.1130/B25317.1, 2004.

Wagner, S.: Dreidimensionale Modellierung zweier Gletscher und Deformationsanalyse von eisreichem Permafrost, Mitteilungen der Versuchsanstalt für Wasserbau, Hydrologie und Glaziologie der ETH Zürich, Switzerland, 135 pp., 1996.

Wang, W., Yang, J., and Wang, Y.: Dynamic processes of 2018 Sedongpu landslide in Namcha Barwa-Gyala Peri massif revealed by broadband seismic records, Landslides, 17, 409-418, https://doi.org/10.1007/s10346-019-01315-3, 2020.

Wang, X., Liu, L., Hu, Y., Wu, T., Zhao, L., Liu, Q., Zhang, R., Zhang, B., and Liu, G.: Progressive advance and runout hazard assessment of a low-angle valley glacier in East Kunlun Mountains from multi-sensor satellite imagery analysis, Nat. Hazards Earth Syst. Sci. Discuss. [preprint], https://doi.org/10.5194/nhess-2021-57, in review, 2021.

Wenying, W.: Glaciers in the north-eastern part of the Ch'ing-haihsi-tsang (Qinghai-Xizang) Plateau (Tibet) and their variations, J. Glaciol., 29, 383-391, 1983.

Zaporozhchenko, E. V. and Chernomorets, S. S.: History and studies of Kazbek blockages, Vestnik Kavkazskogo gornogo obshestva, 5, 33-54, available at: https://istina.msu.ru/download/ 8871273/1k5k36:x_gHoGej2TQCeFRBrQCnhJLg7eU/ (last access: 7 April 2021), 2004 (in Russian).

Zemp, M., Huss, M., Thibert, E., Eckert, N., McNabb, R., Huber, J., Barandun, M., Machguth, H., Nussbaumer, S. U., GartnerRoer, I., Thomson, L., Paul, F., Maussion, F., Kutuzov, S., and Cogley, J. G.: Global glacier mass changes and their contributions to sea-level rise from 1961 to 2016, Nature, 568, 382-386, https://doi.org/10.1038/s41586-019-1071-0, 2019.

Zhang, W. J.: Identification of glaciers with surge characteristics on the Tibetan Plateau, Ann. Glaciol., 16, 168-172, 1992.

Zhao, B., Li, W., Wang, Y., Lu, J., and Li, X.: Landslides triggered by the Ms 6.9 Nyingchi earthquake, China (18 November 2017): analysis of the spatial distribution and occurrence factors, Landslides, 16, 765-776, https://doi.org/10.1007/s10346-019-01146$2,2019$. 